\title{
High-resolution stratigraphy of the Newark rift basin (early Mesozoic, eastern North America)
}

\author{
Paul E. Olsen \\ Dennis V. Kent \\ Bruce Cornet* \\ Lamont-Doherty Earth Observatory of Columbia University, Palisades, New York 10964 \\ William K. Witte* \\ Roy W. Schlische Department of Geological Sciences, Rutgers University, Busch Campus, Piscataway, \\ New Jersey 08855-1179
}

\section{ABSTRACT}

Virtually the entire Late Triassic and earliest Jurassic age section of the early Mesozoic Newark continental rift basin has been recovered in over $6770 \mathrm{~m}$ of continuous core as part of the Newark Basin Coring Project (NBCP). Core was collected using an offset drilling method at seven sites in the central part of the basin. The cores span most of the fluvial Stockton Formation, all of the lacustrine Lockatong and Passaic formations, the Orange Mountain Basalt, and nearly all of the lacustrine Feltville Formation. The cores allow for the first time the full Triassic-age part of the Newark basin stratigraphic sequence to be described in detail. This includes the gray, purple, and red, mostly fluvial Stockton Formation as well as the 53 members that make up the lacustrine Lockatong (mostly gray and black) and Passaic (mostly red) formations. The nearly $25 \%$ overlap zones between each of the stratigraphically adjacent cores are used to test lateral correlations in detail, scale the cores to one another, and combine them in a 4660-m-thick composite section. This composite shows that the entire postStockton sedimentary section consists of a hierarchy of sedimentary cycles, thought to be of Milankovitch climate cycle origin. Lithostratigraphic and magnetostratigraphic correlations between core overlap zones and outcrops demonstrate that the in-

*Present addresses: Cornet: 27 Tower Hill Avenue, Red Bank, New Jersey 07701; Witte: Geophysical Institute, 307B Elvey Building, University of Alaska, Fairbanks, Alaska 99775-0800. dividual sedimentary cycles can be traced essentially basinwide. The agreement between the cyclostratigraphy and magnetostratigraphy shows both the cycles and the polarity boundaries to be isochronous horizons. Detailed analysis of the Newark basin shows that high-resolution cyclostratigraphy is possible in lacustrine, primarily red-bed rift sequences and provides a fine-scale framework for global correlations and an understanding of continental tropical climate change.

\section{This paper is dedicated to the late Alfred Froelich.}

\section{INTRODUCTION}

The beginning of the rifting of Pangea during the Triassic and Early Jurassic resulted in the formation of an extensive series of rift basins along the contiguous boundaries of the North American, African, and Eurasian plates (Fig. 1). In eastern North America, these rifts filled with thousands of meters of continental sediments and igneous rocks termed the Newark Supergroup (Olsen, 1978; Froelich and Olsen, 1984).

Covering over $7000 \mathrm{~km}^{2}$, the Newark ba$\sin$ is the largest of the exposed Newark Supergroup basins (Fig. 2). It is about $190 \mathrm{~km}$ long and maximally $50 \mathrm{~km}$ wide. The basin is connected in the southwest to the Gettysburg basin of Pennsylvania and Maryland by a narrow neck (Figs. 1 and 2), and the latter is separated by a very small strip of basement from the Culpeper basin of Maryland and Virginia. These three basins were most probably connected during sedimentation
(Smoot, 1991), and the original rift was at least as large in area as the present-day Tanganyika or Baikal rifts. The basin provides a complete but relatively poorly exposed section spanning nearly the entire Late Triassic and part of the Early Jurassic (Cornet, 1977). It is a classic rift basin developed in the original Atlantic-type passive margin (Manspeizer, 1988). The basin also contains an exceptionally long record of tropical cyclical climate change recorded in lacustrine strata (Van Houten, 1962, 1964; Olsen, 1986) and presents the prospect of developing a high-resolution chronostratigraphy as has been done, for example, by Hilgen (1991) for the Plio-Pleistocene.

A National Science Foundation-funded project to continuously core the TriassicJurassic Newark rift basin of New York, New Jersey, and Pennsylvania was carried out during 1990-1993. The over $6770 \mathrm{~m}$ of continuous core spanning 30 m.y. recovered by this drilling program, called the Newark Basin Coring Project (NBCP), provides the longest continuous record of a continental rift and lacustrine sequence available anywhere. This paper describes these cores, the stratigraphy of the Newark basin, and tests of two main hypotheses. First, does the entire lacustrine portion (more than threequarters of the section) of the rift sequence consist of a permeating hierarchical pattern of sedimentary cycles caused by cyclical variations in lake level? Second, can the cycles be correlated confidently between cores and with surface sections, including type sections of previously named divisions? The physical stratigraphy described here and its time-stratigraphic significance provides the essential

Data Repository item 9601 contains additional material related to this article.

GSA Bulletin; January 1996; v. 108; no. 1; p. 40-77; 30 figures; 1 table. 


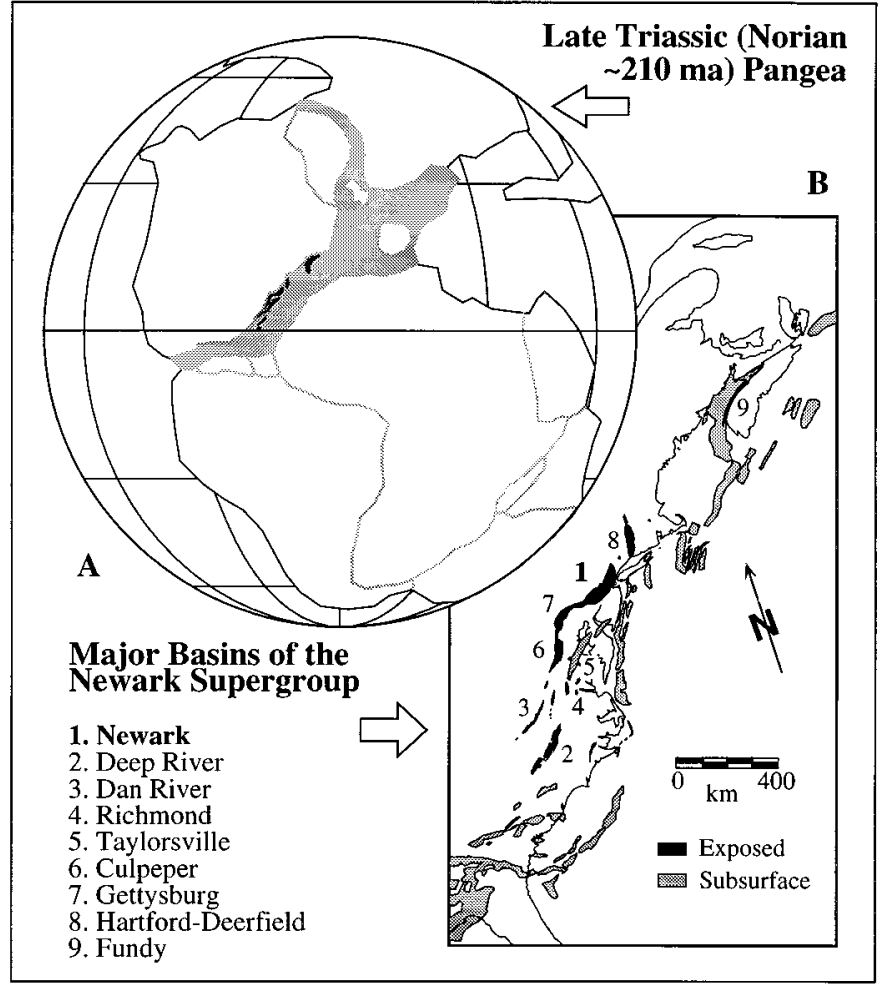

Figure 1. A. Reconstruction of Pangea for the middle Norian showing the zone of early Mesozoic rifting (shaded) and the preserved basins of the Newark Supergroup (black). Continental positions based on Kent et al. (1995) and Witte et al. (1991) and Pangea reconstruction based on Scotese (1986). B. Early Mesozoic rift basins of eastern North America (based on Olsen et al., 1989).

framework for the quantitative assessment of the tectonic evolution of this classic Mesozoic rift (Schlische, 1994), an understanding of the Milankovitch forcing of continental tropical climate change (Olsen and Kent, 1995), and a cyclo- and magnetostratigraphic time scale for global correlations (Kent et al., 1995).

\section{NEWARK BASIN CORING PROJECT}

The Newark basin is a half graben bounded on the northwest by a series of major faults developed on a template of preexisting compressional Paleozoic structures (Ratcliffe and Burton, 1984) and is broken into five northwest-tilted fault blocks (Fig. 2). Folds with northwest- to westtrending axes are present in the hanging walls of all of the fault blocks (Wheeler, 1939; Schlische, 1992). Postrift erosion has removed at least $2 \mathrm{~km}$ of section over the entire basin (e.g., Roden and Miller, 1991; Steckler et al., 1993), and together with these rotated fault blocks and folds, allow much of the Newark basin section to be studied at or near the surface.
The principal objective of the NBCP was to recover the entire Triassic-age portion of the Newark basin section in a series of continuous cores. Because a single, very deep core hole would be prohibitively expensive and involve too much risk to the project goals (e.g., the danger of hitting a major fault at depth), we chose to use an offset coring technique that takes advantage of the eroded and block-faulted half-graben geometry of the basin (Fig. 3). In this method, the core holes were spudded in or just above a specific, easily recognized mapped lithostratigraphic unit or member and continuously cored from the base of a $90 \mathrm{~m}$ cased interval through to another distinctive member at a depth of about $1 \mathrm{~km}$, which was in turn the target to spud into for the next stratigraphically lower core interval. This procedure was followed for the entire section, although not necessarily in stratigraphic order due to logistical constraints. At five of the seven sites, to comply with New Jersey environmental guidelines and meet our coring objectives, it was necessary to drill an additional hole to recover the upper $\sim 90 \mathrm{~m}$ represented by the cased interval in the im- mediately adjacent main hole (see Goldberg et al., 1994). We refer to the deeper core hole as no. 1 and the $90 \mathrm{~m}$ core hole as no. 2 (Table 1). Details of the drilling procedure as well as descriptions of the various logs acquired in the core holes are described in Goldberg et al. (1994). Natural gamma and magnetic susceptibility logs were acquired from the core on site using a pass-through system at all but the Weston site.

We chose to confine the drilling to the eastern and southeastern fault blocks of the central part of the basin (1 and 4 of Fig. 2, respectively). These areas are stratigraphically continuous, contain the largest area of latest Triassic-age strata in the basin, and are relatively uncomplicated structurally. To avoid drilling through the $\sim 300$-m-thick Palisade diabase sill or its correlatives, we drilled along two transects separated by about $40 \mathrm{~km}$. One transect is in the Bound Brook to New Brunswick area, and the other is in the Titusville to Princeton area (Fig. 3). The unit selected to join these transects is the Perkasie Member, one of the most distinctive of the members of the Passaic Formation. To be certain of the identity of the reference units, we mapped eight complete quadrangles and five portions of other 7.5" quadrangles (Figs. 4-6). The veracity of this mapping and identification of units was successfully tested by the coring itself and subsequent stratigraphic analyses.

A total of $6770 \mathrm{~m}$ of continuous core was recovered in the period from November 1990 to March 1993 from the seven coring sites (Figs. 7 and 8). The statistics for all the cores are given in Table 1. The oldest strata cored belong to the lower Stockton Formation of Carnian age and the youngest belong to the upper Feltville Formation of Hettangian age. All of the Lockatong Formation, Passaic Formation, and Orange Mountain Basalt were cored. On average there is nearly $25 \%$ overlap between stratigraphically adjacent cores, and in all cases, at least two members occur in the overlap zones. Correlation between holes was made on the basis of lithology and in all cases was corroborated by paleomagnetic polarity stratigraphy. Correlation between the cores allows us to scale the cores to each other and to construct a composite stratigraphic section.

\section{STRATIGRAPHIC AND CYCLOSTRATIGRAPHIC NOMENCLATURE}

Newark basin strata have been studied for over 130 yr (e.g., Redfield, 1856). The cur- 


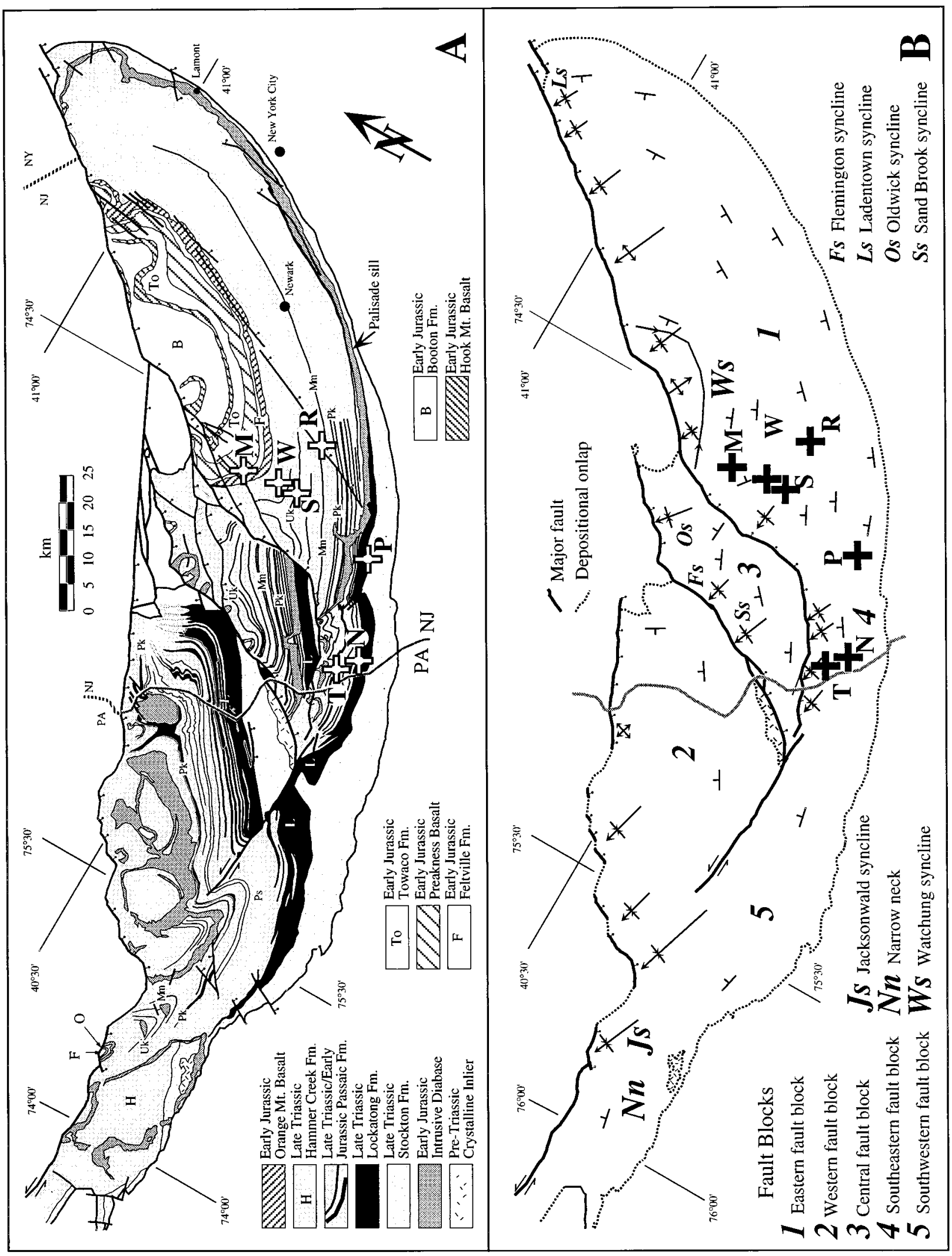

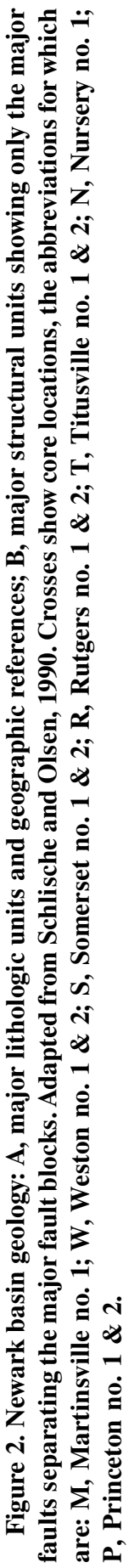




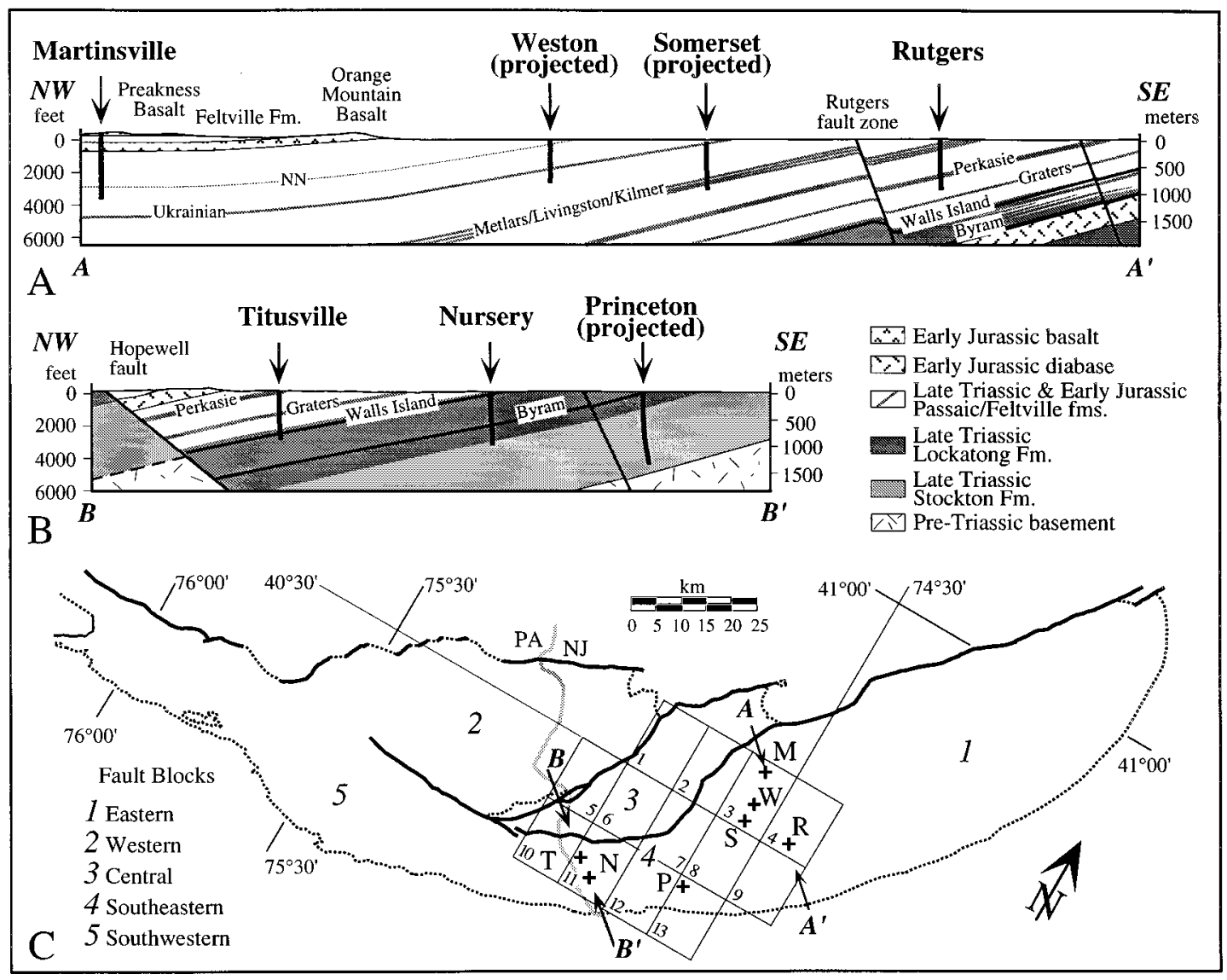

Figure 3. Cross sections and index map of the Newark basin showing the relative positions of the Martinsville, Weston, Somerset, Rutgers, Titusville, Nursery, and Princeton core holes. A. Cross section of the Bound Brook to New Brunswick core transect in the Northern Newark basin. B. Cross section of the Titusville to Princeton core transect in the south-central Newark basin. C. Index map showing the positions of the two core transects $\left(A-A^{\prime}\right.$ and $\left.B-B^{\prime}\right)$, core holes, and the various $7.5^{\prime}$ quadrangles, portions of which were mapped during the Newark Basin Coring Project. Quadrangles: 1, Flemington; 2, Raritan; 3, Bound Brook; 4, Plainfield; 5, Stockton; 6, Hopewell; 7, Rocky Hill; 8, Monmouth Junction; 9, New Brunswick; 10, Lambertville; 11, Pennington; 12, Princeton; 13, Hightstown. Core hole abbreviations as in Figure 2.

TABLE 1. NEWARK BASIN CORING PROJECT CORE AND HOLE STATISTICS

\begin{tabular}{|c|c|c|c|c|c|c|c|c|c|c|c|}
\hline Name & $\begin{array}{c}\text { Latitude } \\
\text { and } \\
\text { longitude }\end{array}$ & $\begin{array}{l}\text { Well head } \\
\text { elevation } \\
(\mathrm{m})^{*}\end{array}$ & $\begin{array}{l}\text { No. } 1 \\
\text { top } \\
\text { (m)* }\end{array}$ & $\begin{array}{c}\text { No. } 1 \\
\text { bottom } \\
\text { (m)* }\end{array}$ & $\begin{array}{l}\text { Interval } \\
\text { cored } \\
(\mathrm{m})^{*} \\
\end{array}$ & $\begin{array}{c}\text { No. } 2 \\
\text { top } \\
\text { (m)* }\end{array}$ & $\begin{array}{c}\text { No. } 2 \\
\text { bottom } \\
\text { (m)* }\end{array}$ & $\begin{array}{c}\text { Interval } \\
\text { cored } \\
(\mathrm{m})^{*}\end{array}$ & $\begin{array}{c}\text { Total } \\
\text { depth } \\
\text { Drilled }(\mathrm{m})^{*} \\
\end{array}$ & $\begin{array}{c}\text { Core } \\
\text { recovery } \\
\% \\
\end{array}$ & Loss \\
\hline 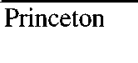 & $\begin{array}{l}40^{\circ} 22^{\prime} 09^{\prime \prime} \\
74^{\circ} 36^{\prime} 49^{\prime \prime}\end{array}$ & $\begin{array}{r}36.6 \\
(120)\end{array}$ & $\begin{array}{c}93.9 \\
(308.0)\end{array}$ & $\begin{array}{c}1126.9 \\
(3697.0)\end{array}$ & & $\begin{array}{c}14.0 \\
(46.0)\end{array}$ & $\begin{array}{c}96.9 \\
(318.0)\end{array}$ & $\begin{array}{c}82.9 \\
(272.0)\end{array}$ & $\begin{array}{c}1126.8 \\
(3697.0)\end{array}$ & 99.9 & $\begin{array}{c}1.4 \\
(4.7)\end{array}$ \\
\hline urse & & & $\begin{array}{c}95.1 \\
(312.0)\end{array}$ & $\begin{array}{l}1008.6 \\
(3309.0\end{array}$ & & N.D. & N.D. & N.D. & $\begin{array}{c}1008.9 \\
(3310.0)\end{array}$ & 100.0 & $\begin{array}{c}0.2 \\
(0.5)\end{array}$ \\
\hline Titusville & $\begin{array}{l}40^{\circ} 19^{\prime} 35^{\prime \prime} \\
74^{\circ} 51^{\prime} 02^{\prime \prime}\end{array}$ & $\begin{array}{c}73.2 \\
(240)\end{array}$ & $\begin{array}{c}94.2 \\
(309.0)\end{array}$ & $\begin{array}{c}924.9 \\
(3034.5)\end{array}$ & $\begin{array}{c}830.7 \\
(2725.5)\end{array}$ & $\begin{array}{c}8.2 \\
(27.0)\end{array}$ & $\begin{array}{c}93.9 \\
(308.0)\end{array}$ & $\begin{array}{c}85.6 \\
(281.0)\end{array}$ & $\begin{array}{c}925.1 \\
(3035.0)\end{array}$ & 99.8 & $\begin{array}{l}1.5 \\
(5.0)\end{array}$ \\
\hline itge & $\begin{array}{l}40^{\circ} 32^{\prime} 33^{\prime \prime} \\
74^{\circ} 26^{\prime} 00^{\prime \prime}\end{array}$ & $\begin{array}{r}39.6 \\
(130)\end{array}$ & $\begin{array}{c}93.3 \\
(306.1)\end{array}$ & $\begin{array}{c}943.4 \\
(3095.0)\end{array}$ & $\begin{array}{c}850.1 \\
(2788.9)\end{array}$ & $\begin{array}{c}8.8 \\
(27.0)\end{array}$ & $\begin{array}{c}97.8 \\
(321.0)\end{array}$ & $\begin{array}{c}89.6 \\
(294.0)\end{array}$ & $\begin{array}{c}943.4 \\
(3095.0)\end{array}$ & 99.9 & $\begin{array}{c}1.2 \\
(4.0)\end{array}$ \\
\hline iomerset & $\begin{array}{l}40^{\circ} 30^{\prime} 31^{\prime \prime} \\
74^{\circ} 33^{\prime} 58^{\prime \prime}\end{array}$ & & $\begin{array}{c}93.6 \\
(307.0)\end{array}$ & $\begin{array}{c}917.3 \\
(3009.5)\end{array}$ & $\begin{array}{c}823.7 \\
(2702.5)\end{array}$ & $\begin{array}{c}7.3 \\
(24.0)\end{array}$ & $\begin{array}{c}96.0 \\
(315.0)\end{array}$ & $\begin{array}{c}88.7 \\
(291.0)\end{array}$ & $\begin{array}{c}917.4 \\
(3010.0)\end{array}$ & 99.3 & $\begin{array}{c}6.8 \\
(22.4)\end{array}$ \\
\hline Wes & $\begin{array}{l}40^{\circ} 32^{\prime} 33^{\prime \prime} \\
74^{\circ} 33^{\prime} 49^{\prime \prime}\end{array}$ & 13.7 & $\begin{array}{c}92.2 \\
(302.6)\end{array}$ & $\begin{array}{c}792.9 \\
(2601.4)\end{array}$ & $\begin{array}{c}700.7 \\
(2298.8)\end{array}$ & $\begin{array}{c}6.7 \\
(22.0)\end{array}$ & $\begin{array}{c}94.6 \\
(310.4)\end{array}$ & $\begin{array}{c}87.9 \\
(288.4)\end{array}$ & $\begin{array}{c}793.1 \\
(2602.0)\end{array}$ & 100.0 & $\begin{array}{r}<0.3 \\
(<1.0)\end{array}$ \\
\hline Martinsville & $\begin{array}{l}40^{\circ} 37^{\prime} 09^{\prime \prime} \\
74^{\circ} 34^{\prime \prime} 22^{\prime \prime} \\
\end{array}$ & $\begin{array}{r}140.2 \\
(460) \\
\end{array}$ & $\begin{array}{r}39.6 \\
(130.0) \\
\end{array}$ & $\begin{array}{c}1223.8 \\
(4015.0) \\
\end{array}$ & $\begin{array}{c}1184.1 \\
(3885.0) \\
\end{array}$ & N.D. & N.D. & N.D. & $\begin{array}{c}1223.8 \\
(4015.0) \\
\end{array}$ & 100.0 & $\begin{array}{c}0.0 \\
(0.1) \\
\end{array}$ \\
\hline
\end{tabular}

* Numbers in parentheses are in feet.

N.D. = not drilled 


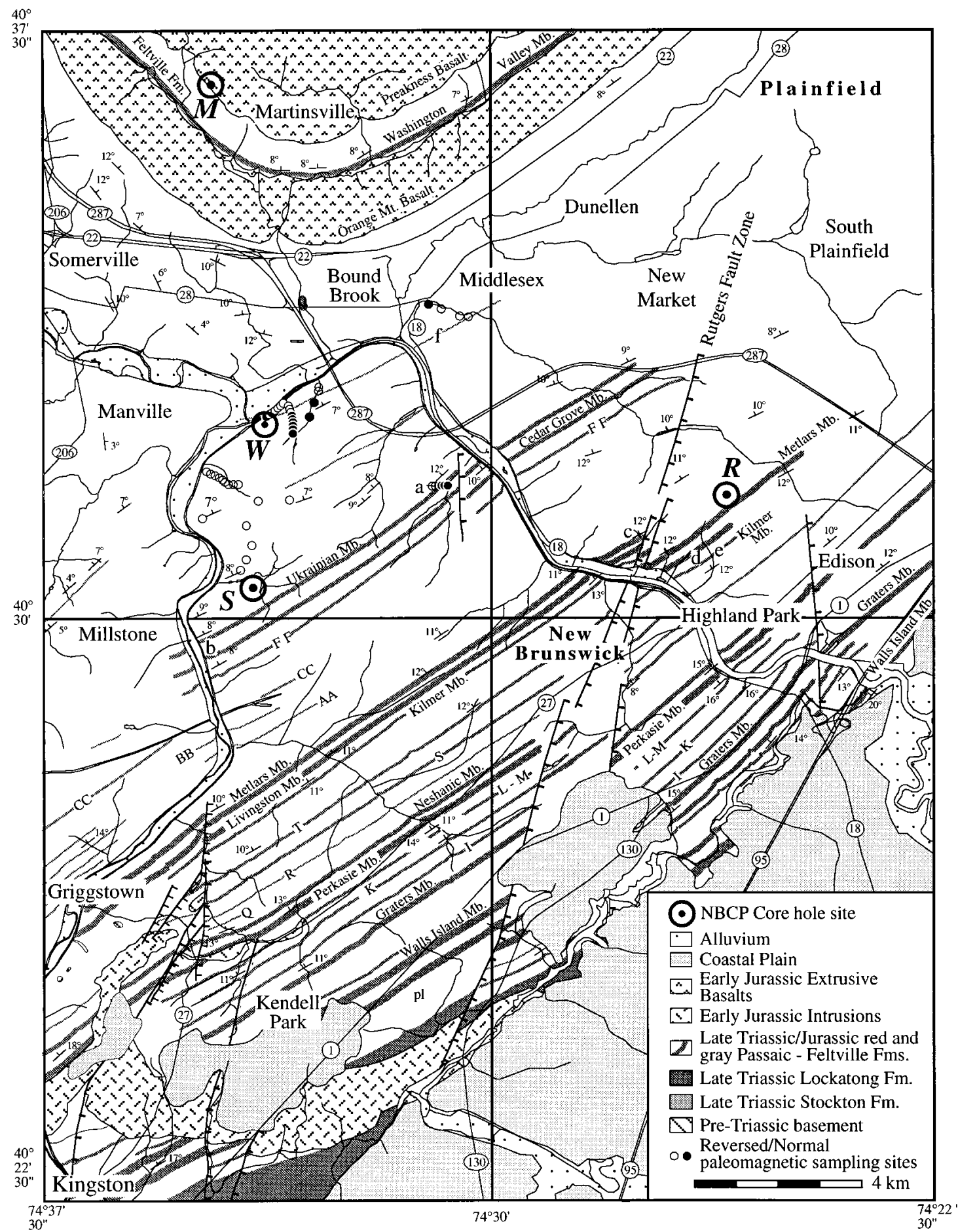

Figure 4. Map of the Bound Brook to New Brunswick area. From the upper left, in clockwise order, the quadrangles are Bound Brook, Plainfield, New Brunswick, and Monmouth Junction (see Fig. 3B for index map). Core sites: $M$, Martinsville; $W$, Weston; $S$, Somerset; $R$, Rutgers. Abbreviations: a, Ukrainian Member type section; b, Cedar Grove Member type section; c, Metlars Member type section; d, Livingston Member type section; e, Kilmer Member type section; F, Feltville Formation; f, boundary between magnetic polarity units E21n and E21r based on surface paleomagnetic samples; p1, portion of Passaic Formation equivalent to Lockatong Formation in type area, but here dominated by red beds. Map data are based on original observations, Parker and Houghton (1990), and Bayley et al. (1914). 




Figure 5. Map of the Titusville to Princeton area. Key to units and scale as in Figure 4. The mapped quadrangles, from left to right: eastern part of the Lambertville; Pennington; Princeton; western part of the Hightstown. Core sites: $T$, Titusville; $N$, Nursery; $P$, Princeton. Map data are based on Bayley et al. (1914), McLaughlin (1959), Parker and Houghton (1990), Jones (1994), and original observations.

rently accepted stratigraphic nomenclature was established by Kümmel (1897) and Darton $(1889,1890)$, who recognized four fundamental lithological divisions of the Newark basin section (Fig. 9). These are, from bottom to top, (1) a mostly buff and red conglomerate, arkose, and mudstone unit named the Stockton Formation; (2) a mostly gray mudstone unit termed the Lockatong Formation; (3) a mostly red mudstone, sandstone, and conglomerate called the Brunswick Formation; and (4) a series of three compound basalt flow units called the Watchung Basalt interstratified with the Brunswick Formation (Bayley et al., 1914). Glaeser (1963) applied the name Hammer Creek Conglomerate to the mostly red coarse clastic rocks in the area between the Newark and Gettysburg basins.

The Watchung Basalt of Darton (1889) lies stratigraphically far above what had been recognized as upper Brunswick Formation. Detailed biostratigraphic study showed that the youngest units in the western fault block in New Jersey and Pennsylvania are of middle Late Triassic age, whereas the strata interbedded between the Watchung Basalt flows are Early Jurassic in age (Cornet, 1977). Olsen (1980a) recog- nized that the strata interbedded with and overlying the Watchung Basalt differed lithologically from underlying units, and each of the major sedimentary sequences surrounding the basalts were equivalent in scale to the formations recognized in the nearby Hartford basin by Lehmann (1949).

Olsen (1980a) proposed that the terms Brunswick Formation and Watchung Basalt be abandoned and replaced by seven new formations following the formational framework established in the Hartford basin. These formations are, from the bottom up, Passaic Formation, Orange Mountain Basalt, Feltville Formation, Preakness Basalt, Towaco Formation, Hook Mountain Basalt, and Boonton Formation. Lyttle and Epstein (1987) resurrected the term Brunswick as a group name to include the subdivisions of Olsen (1980a) in New Jersey and termed all of the strata above the Lockatong Formation in Pennsylvania the Brunswick Group undivided. Lutrell (1989) reviewed Newark basin stratigraphic nomenclature (as well as that of the rest of the Newark Supergroup) and officially recognized Lyttle and Epstein's nomenclature, as well as the formations of Olsen (1980a). Here we generally follow the nomenclature of Olsen (1980a) (Figs. 7 and 9).

Originally it was believed that a complete stratigraphic section of the basin was represented in the western fault block and that the Watchung flows were interbedded with equivalents of the upper parts of the section in the eastern fault block (Van Houten, 1969). However, biostratigraphic studies by Baird (1957) on footprints, Cornet (1977) and Cornet et al. $(1973,1975)$ on palynomorphs, and Olsen (1980c) on vertebrate osseous remains have shown that the units above the Lockatong Formation in the western fault block make up only the lower third of the Passaic Formation. However, largely because of poor outcrop, the stratigraphy of the upper two-thirds of the Passaic Formation, making up nearly one-third of the entire basic section, remained essentially unknown until the NBCP cores were drilled.

The Lockatong and Passaic formations are largely lacustrine and profoundly cyclical at several scales (Van Houten, 1964; Olsen, 1986; Smoot, 1991). Van Houten (1964, 1969, 1980) first observed that a hierarchy of cycles is present in the Lockatong Formation, consisting of relatively thin lake level cycles making several orders of compound 


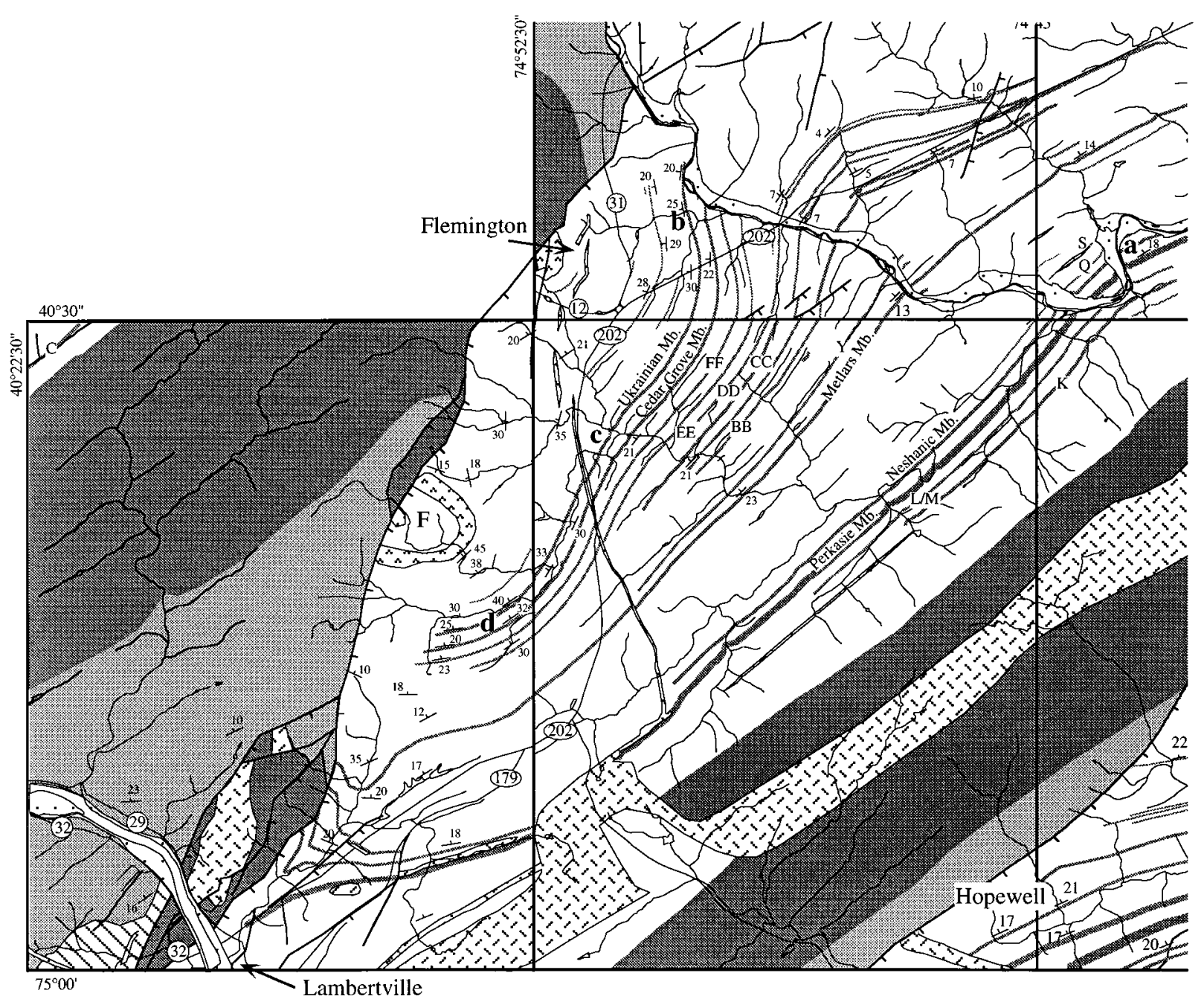

Figure 6. Map of the Sand Brook to Flemington area. Key to units and scale as in Figure 4. The mapped quadrangles, clockwise from the upper left: southern half of the Flemington; southwestern portion of the Raritan; Stockton; Hopewell; western part of the Rocky Hill. Abbreviations: a, type section of the Neshanic Member; b, section 4 in Figure 25; c, section 5 in Figure 25; d, section 6 in Figure 25; F, Feltville Formation. Map data are based on original observations, Parker and Houghton (1990), Bascom et al. (1909a, 1909b), Bayley et al. (1914), and Ratcliffe and Burton (1988).

cycles. Van Houten ascribed these sedimentary cycles to control of climate by celestial mechanics. Olsen (1986) showed that such cyclicity is present in the Passaic Formation as well. This cyclicity provides a physical means of subdividing the Lockatong and Passaic Formations into mappable units that are recognizable in the cores.

In detail, we recognize four basic types of lacustrine sedimentary cycles in the Newark basin (Fig. 10): (1) the Van Houten cycle, (2) the short modulating cycle, (3) the McLaughlin cycle, and (4) the long modulating cycle. Of the compound cycles, the expression of McLaughlin cycle is the strongest, and that of the long modulating cycles is the weakest (see Olsen and Kent [1995] for a quantitative analysis). The McLaughlin cycle constitutes the unit of appropriate scale for map-scale subdivision.

Van Houten's lake level cycles are the thinnest of these sedimentary sequences and were named after their discoverer (Olsen, 1986). Van Houten cycles consist of three divisions. Division 1 is a relatively thin unit, generally massive at its base, becoming better bedded upward as the density of desiccation cracks and/or tubes (root or burrows) decreases. Division 2 has the best-developed bedding in the cycle and commonly consists of gray or black fissile mudstone. Division 3 becomes more massive upward by an increase in the frequency of desiccation cracks and/or tubes. Divisions 1 and 3 may be gray, purple, or red with lighter colors predominating, whereas division 2 can be red, purple gray, or black with darker colors being common. Evaporite pseudomorphs are often present in the upper parts of division 2 and 3 . Van Houten cycles appear to be caused by the rise and fall of lake level controlled by precipitation governed by the $\sim 20000 \mathrm{yr}$ climatic precession cycle (Van Houten, 1964, 1969; Olsen, 1986; Olsen and Kent, 1995). Black and gray finely laminated mudstones were deposited by relatively deep, perennial lakes during humid times, whereas gray and red mudcracked or rooted massive mudstones were produced by ephemeral lakes during more arid intervals (Smoot, 1991). Details of the variations in Van Houten cy- 


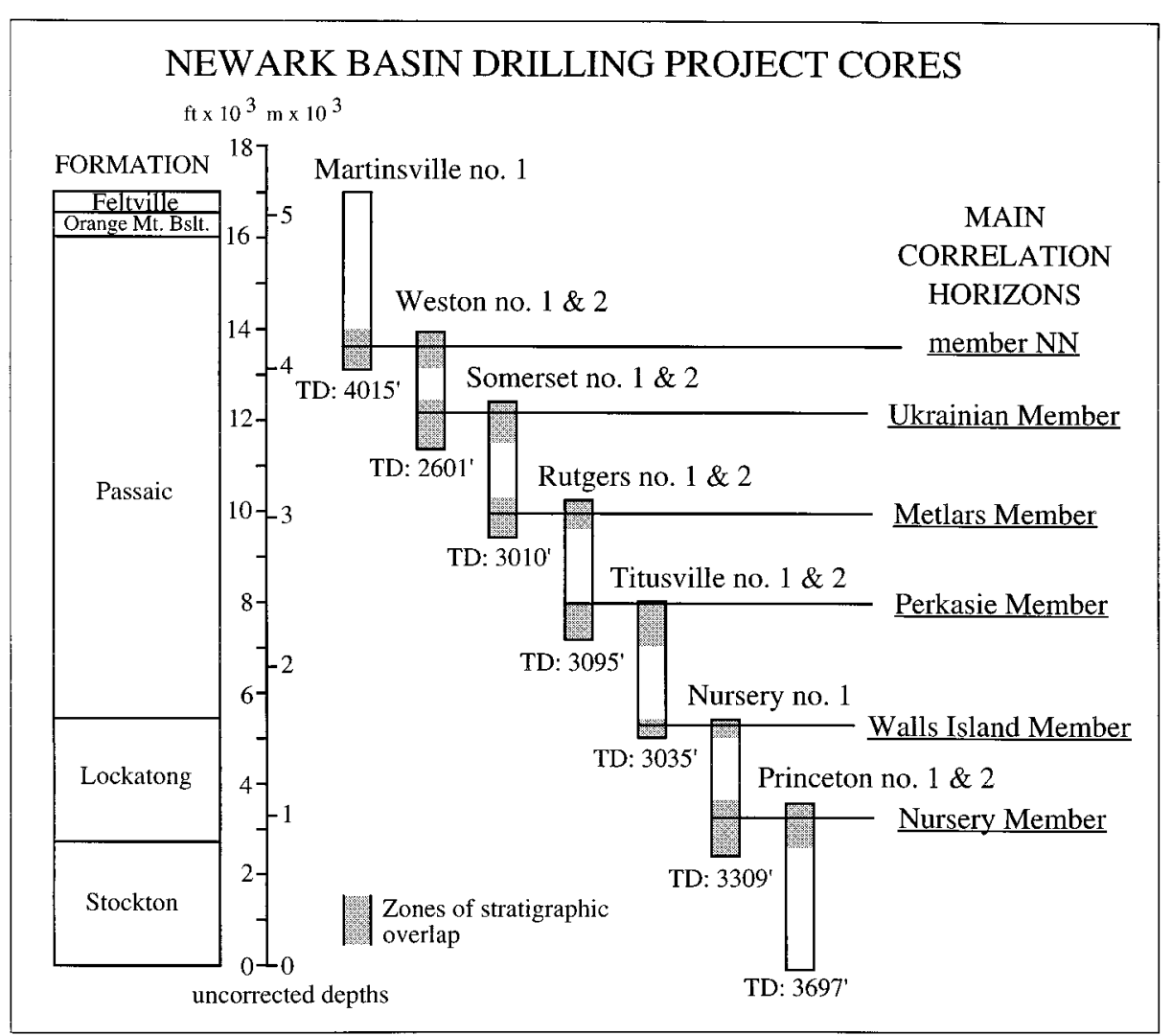

Figure 7. Stratigraphic distribution of cores from the Newark Basin Coring Project showing the main correlation horizons between stratigraphically adjacent cores. All depths are based on the core depths, marked on the cores by the drillers, and are not corrected for contraction or expansion of core relative to the core hole, the dip of strata, bore-hole deviation, or changes in thickness between correlative sections (see Fig. 30). The cumulative depth scale reflects only the total amount of stratigraphically nonoverlapping core drilled.

cles in the NBCP cores have been described in detail by Smoot and Olsen (1994).

Short modulating cycles are expressed as a sequence of from four to six Van Houten cycles (averaging five) in which the degree of development of lamination and black and drab colors is modulated through the sequential Van Houten cycles. As we show them in Figure 9, the lower Van Houten cycles in a short modulating cycle tend to be dominated by drab and dark colors; division 2 tends to be thick, black, and finely laminated. In the upper parts of the modulating cycles, the Van Houten cycles tend to be mostly red, and division 2 is usually red, purple, or gray fissile mudstone. For convenience we have designated the first well-developed dark-colored bed as the base of short modulating cycles and the cycles thus appear asymmetrical. However, the variation in the Van Houten cycles is in fact sinusoidal. Short modulating cycles appear to be the expression in climate (precipita- such as in parts of the Passaic Formation, the upper parts of McLaughlin cycles often have little or no expression of Van Houten cycles in color, although the cycles still show up as variations in sedimentary structures or geophysical properties (Reynolds, 1994; Silvestri, 1994). As is true for the short modulating cycles, we place the base of the McLaughlin cycle at the first well-developed dark-colored bed, producing an asymmetrical-looking cycle; however, the true variation in short modulating cycles is again sinusoidal. McLaughlin cycles were produced by climatic variations again tied to modulation of the climatic precession cycle, but this time by the $413000 \mathrm{yr}$ cycle of eccentricity of the Earth's orbit.

Long modulating cycles (Fig. 10) are composed on average of four or five McLaughlin cycles. They recapitulate the pattern of variation seen in the shorter modulating cycles with McLaughlin cycles dominated by gray and black units appearing low in the cycle and red units tending to dominate in the upper parts of the cycle. The long modulating cycle may be the result of control of the climatic precession cycle by the $\sim 2$ m.y. cycle of eccentricity of the Earth's orbit (Olsen and Kent, 1995).

McLaughlin cycles provide a convenient lithological means to subdivide the Lockatong and Passaic formations. McLaughlin (1933, 1944, 1946a, 1946b, 1959) gave letter designations to the mapped gray and black units within the lower Passaic and upper Lockatong formations of the Hunterdon Plateau (western fault block), with A being the stratigraphically lowest and $\mathrm{O}$ being the highest. These mapped gray and black portions of the section are commonly the lower parts of the McLaughlin cycles, although some are the lower parts of individual short modulating cycles. McLaughlin (1946a, 1946b) clearly demonstrated that these units are laterally continuous at the scale of tens of kilometers.

Olsen (1980b) modified McLaughlin's nomenclatural system by recognizing each member as a couplet composed of a lower more gray and black interval and an upper more red or light gray interval, essentially recognizing the McLaughlin cycle as a member. Operationally, we define the base of each member at the lowest distinct transition from underlying more massive red or gray units upward into more fissile black, gray, purple, or rarely red units (Fig. 10). We follow McLaughlin's lead and apply informal letter designations to most of the divisions of the Passaic Formation (Fig. 11). 
PRINCETON \# 1 \& 2

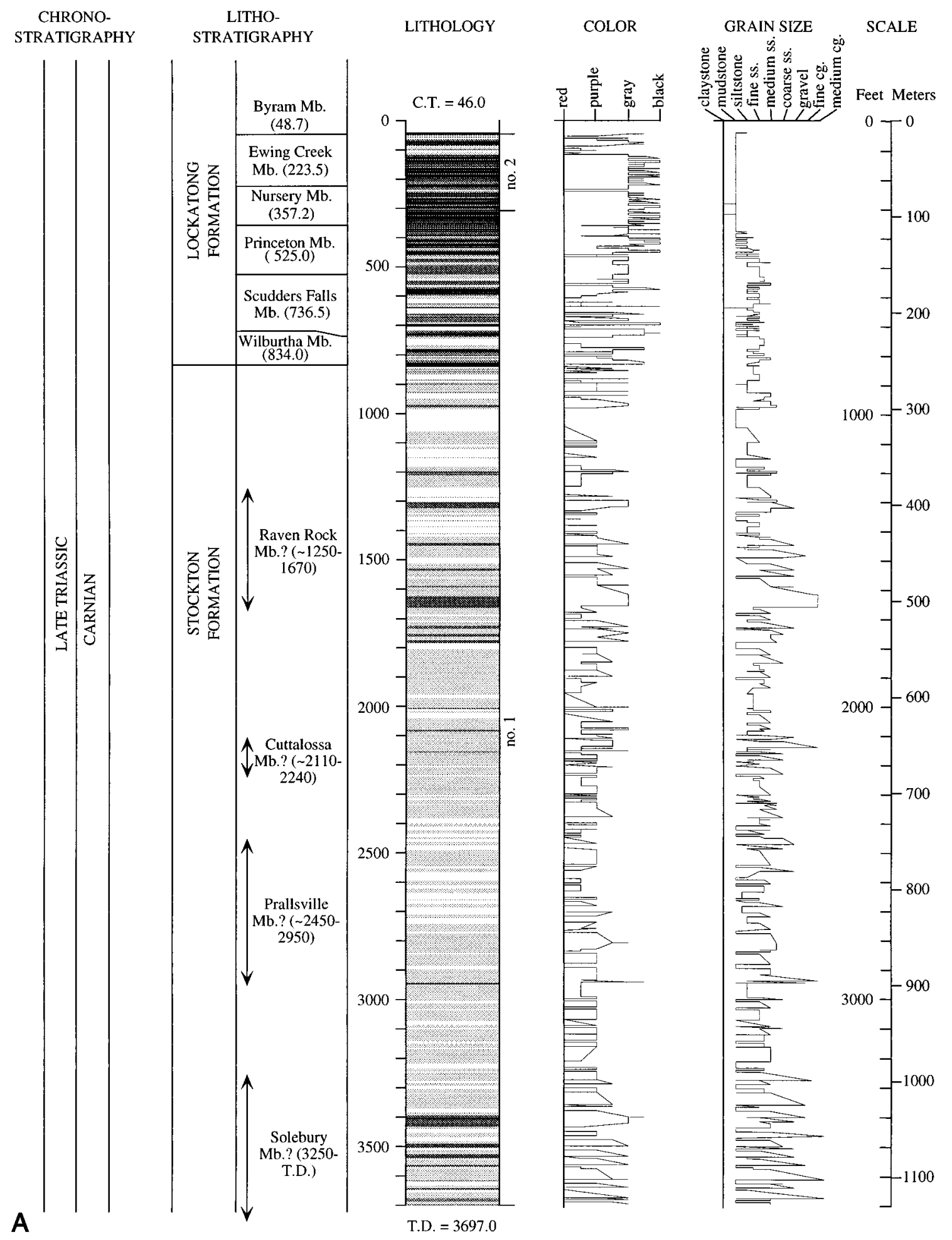

Figure 8. Lithology logs from the cores from the Newark Basin Coring Project: A, Princeton; B, Nursery; C, Titusville; D, Rutgers; E, Somerset; F, Weston; G, Martinsville. Lithological log symbols (key shown in B) reflect color and igneous rocks: white indicates red sedimentary rock; light gray indicates purple to white sedimentary rock; dark gray indicates gray sedimentary rocks, black indicates black and dark gray sedimentary rock; and upside down $\mathrm{V}$ pattern indicates tholeiitic igneous rock (basalt in Martinsville and diabase in Rutgers). Munsell color equivalents: red, 10R 4/6-5R 4/6, 5YR 4/4, 5YR 3/4, 5YR 5/6; purple, 5R 6/2, 5R 4/2, 5R 5/4, 10R 4/2, 10R 6/2, 5P, 6/2, 5RP 6/2 (occasionally white, 5RP 8/2, N8, 5Y 8/1, 5Y 8/1); gray, N7-N5, 5B 5/1, 5G 4/1; and black, N2-N1, 5YR 2/1, 5Y 2/1, 5GY 2/1, 5G 2/1. All grain sizes are qualitative, judged from the core wall, and are hence somewhat subjective. Depths are uncorrected core depth as marked on the core by the drillers and core handlers. C.T., core top; T.D., total depth. 
NURSERY \# 1

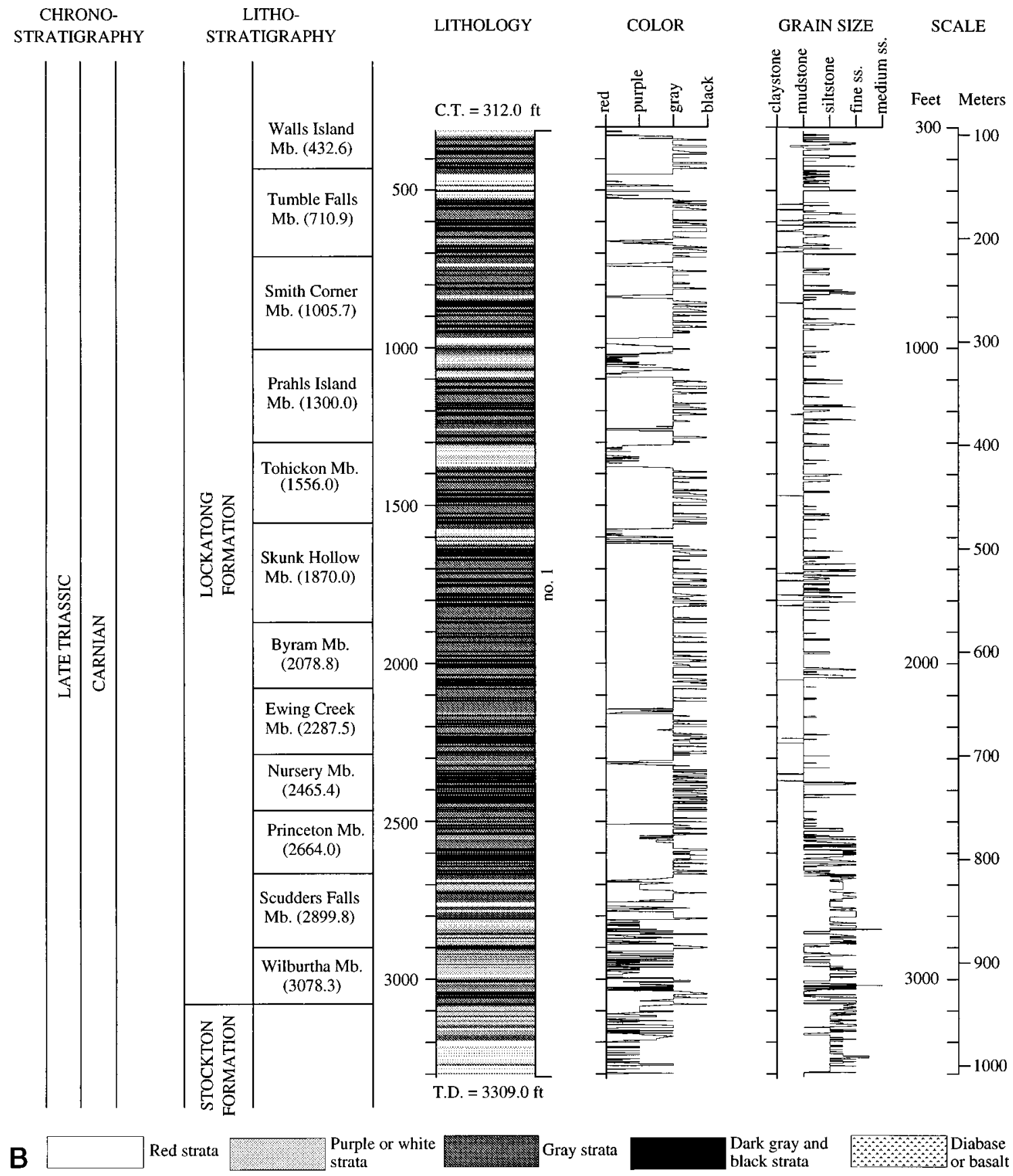

Figure 8. (Continued).

Based on the coring results, we adopt McLaughlin's letter designation for the Perkasie (N-O; Drake et al., 1961) and designate successive members as $\mathrm{P}$, then $\mathrm{Q}$, and so on to $\mathrm{Z}$, followed by $\mathrm{AA}, \mathrm{BB}$, to $\mathrm{VV}$. Also, like McLaughlin, we propose several new formal member names for specific, easily recognizable and mappable units (Fig. 11). These formal names exist in par- allel to the letter designations. We use this dual nomenclatural scheme because it provides convenient terms for all of the units of similar rank within the Passaic and Lockatong formations, but without the necessity and encumbrance of a sequence of a large number of formal names. The letter designations also have the advantage of placing a specific unit immediately into its relative po- sition within the sequence, with oftencited and especially distinctive units also receiving formal place names. This lithological subdivision recognizes the McLaughlin cycle as a fundamental stratigraphic unit of the Newark basin sequence, while retaining the units that McLaughlin defined as members.

It is important to note that in this nomen- 
OLSEN ET AL.

TITUSVILLE \# $1 \& 2$

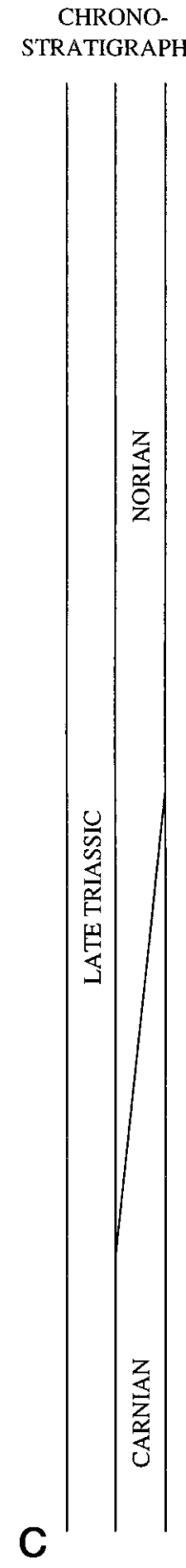

LITHOSTRATIGRAPHY

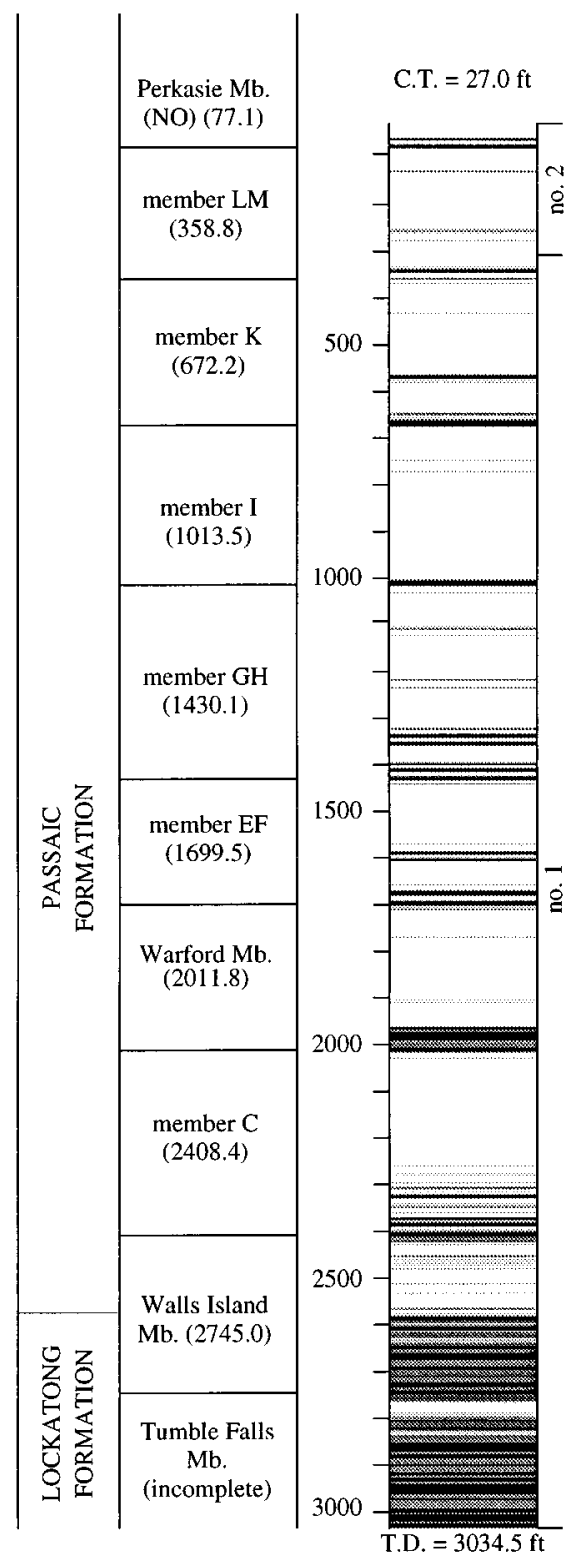

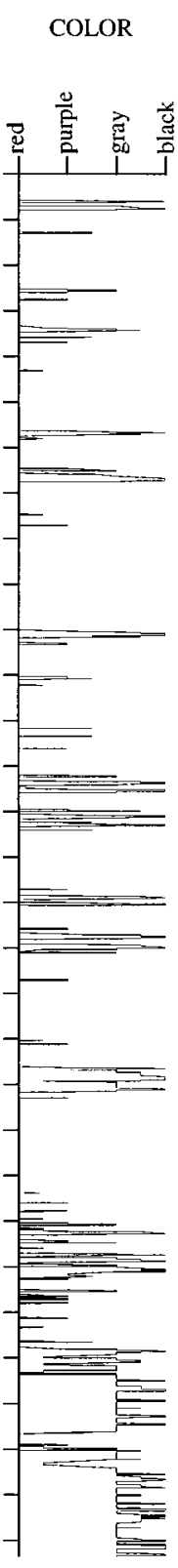

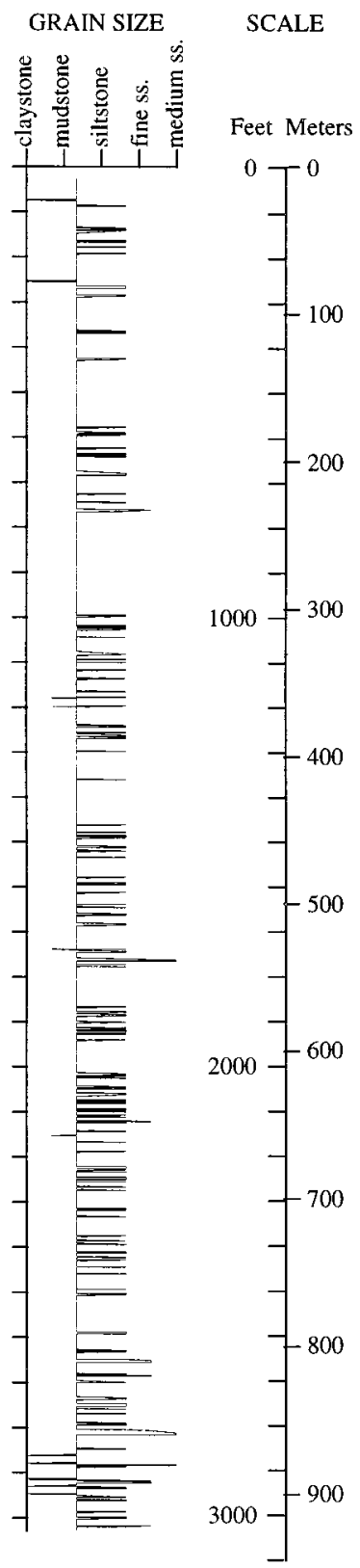

Figure 8. (Continued).

clatural system, member boundaries are not necessarily contiguous with formational boundaries. For example, the boundary between the Lockatong and Passaic formations is within the Walls Island Member in the type area of the Lockatong Formation, not at the base of member $\mathrm{C}$, because the base of the Passaic Formation is defined by the dominance of red beds, which in the type area composes the upper half of the Walls Island Member. In addition, where the members of the upper part of the Lockatong extend along strike outside their type area in the middle portion of the Newark basin, the gray portions of the members decline in thickness and the now dominantly red members become part of the Passaic Formation (see Fig. 3A). The formational boundary between the Passaic and Lockatong formations shifts stratigraphically downward and is thus time-transgressive, although the members continue laterally over the basin and are believed to be isochronous units (see below).

\section{STRATIGRAPHIC DESCRIPTION AND CORRELATION}

\section{Stockton Formation}

Kümmel (1897) named the Stockton Formation for outcrops of buff and gray arkose and pebbly arkose, and red sandstone and mudstone in the vicinity of Stockton, New Jersey. The Stockton Formation makes up the basal formation over most of the Newark basin. 
RUTGERS \# $1 \& 2$
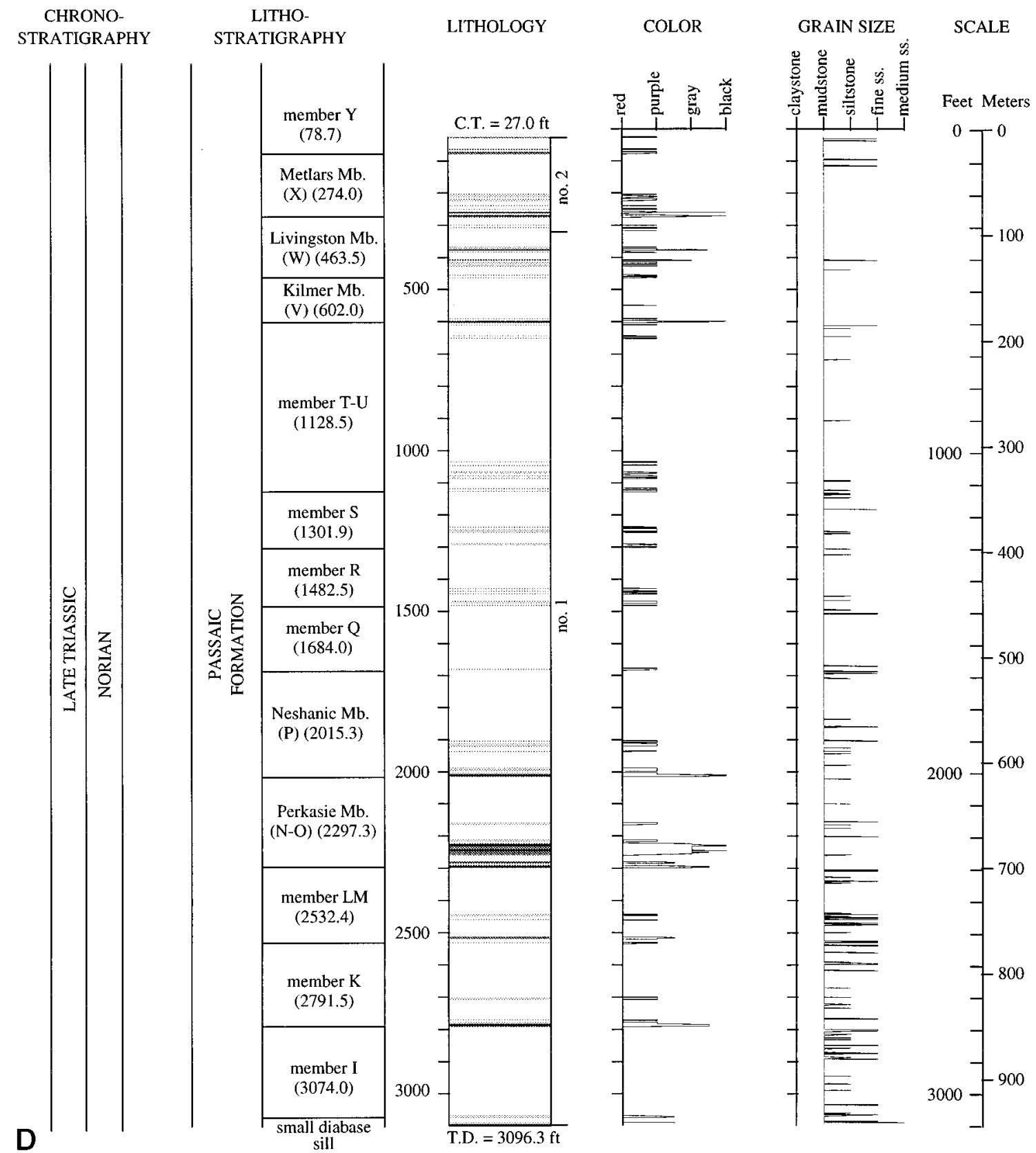

Figure 8. (Continued).

McLaughlin (1945) and Johnson and McLaughlin (1957) described the type section of the Stockton Formation along the Delaware River and recognized five members (Fig. 12). These members are different in conception and scale than the members of the Lockatong and Passaic formations and are intervals dominated by coarse clastics (mostly arkose and pebbly arkose). For the most part, these named members have not been formally recognized outside the west- ern fault block (e.g., Rima et al., 1962). The Stockton Formation is dominated by fluvial sequences (Van Houten, 1969; Smoot, 1991), and, consequently, Stockton sections probably cannot be correlated with the same degree of precision with which we can correlate the younger lacustrine section.

The Stockton Formation occurs in the Princeton no. 1 core from $254.2 \mathrm{~m}$ to 1126.8 m (T.D. [total depth]) and the Nursery no. 1 core from $968.7 \mathrm{~m}$ to $1008.6 \mathrm{~m}$ (T.D.) (Figs. 8A and 8B). Here, most of the Stockton consists of 5- to 10-m-thick fining-upward cycles of buff, white, and gray arkose or pebbly arkose, grading upward into brown heavily bioturbated mudstone. In general, small-scale sedimentary structures are difficult to see in the sandstones, presumably due to bioturbation. Carbonate nodules are abundant in many mudstones, and interclast conglomerates are abundant within the sand- 
OLSEN ET AL.

SOMERSET \# $1 \& 2$
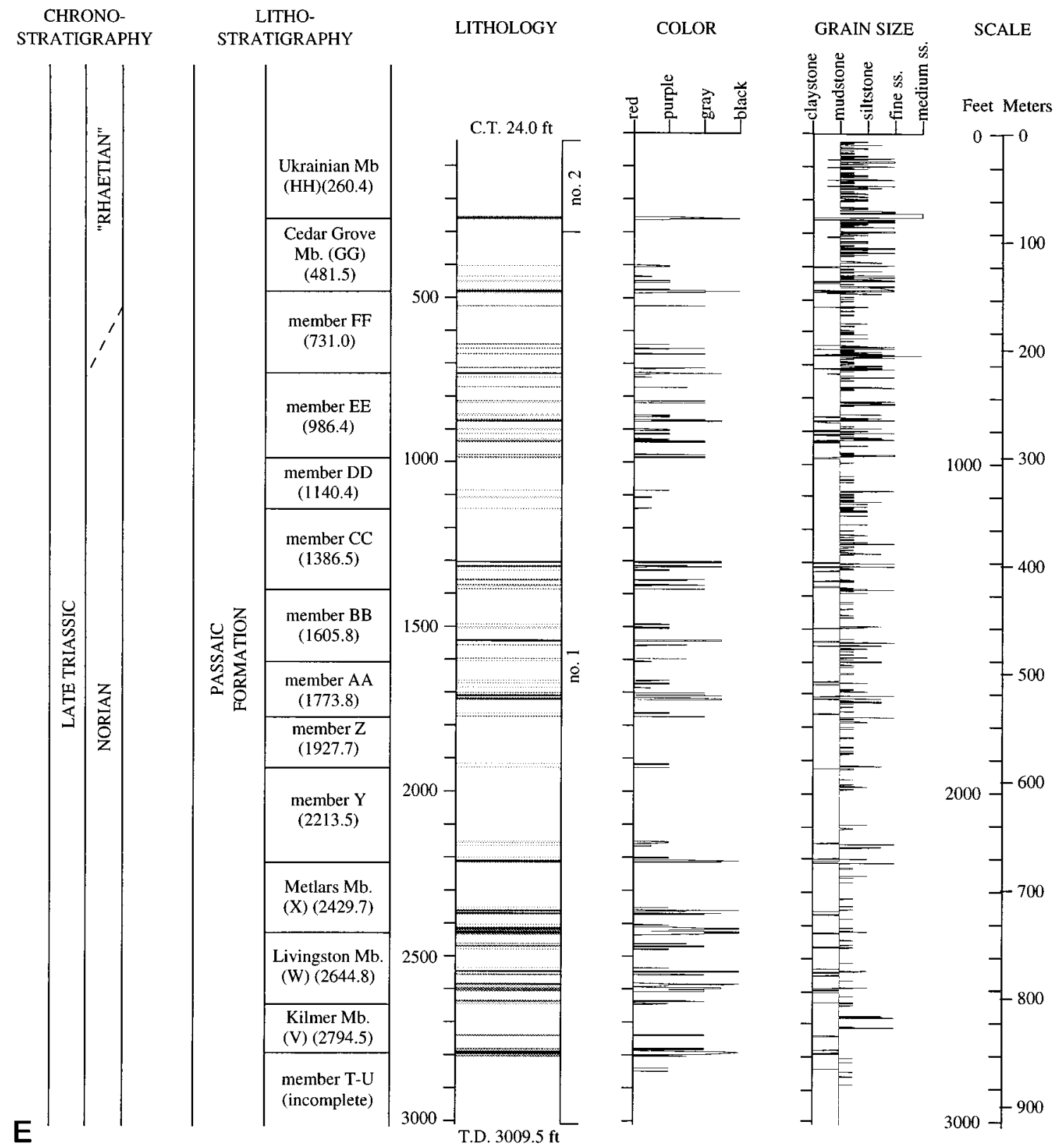

Figure 8. (Continued).

stones. Most thicker sandstone and pebbly sandstone sequences are gray or white and are interbedded with minor amounts of gray mudstone.

In general, the Stockton Formation in the cores is lithologically very similar to the outcrops of the type section. The boundary between the upper Stockton and lower Lockatong formations is at the base of the lowest prominent black or gray shale sequence in the lower part of the Wilburtha Member (Figs. 8A and 8B). Comparison of the
Princeton no. 1 core and the type section in outcrop suggests a correlation in which two different, but stratigraphically close, gray and black units mark the base of the Lockatong Formation, and thus the boundary between the two formations changes slightly laterally (Fig. 12). The thickness of sedimentary cycles in the basal Lockatong Formation in its type area (as seen at Byram, New Jersey) is $177 \%$ of that in the correlative portion of the Princeton no. 1 core. If the Stockton Formation in outcrop is similarly expanded relative to that in the Princeton no. 1 core, there would be a close match between the position of major sand and conglomerate-rich parts of the section (Fig. 12). This proportional relationship between core and outcrop suggests that the members of the Stockton Formation identified by McLaughlin (1945) can be identified in the Princeton core (Fig. 8A). Overall, the Stockton Formation tends to fine upward, with the uppermost $102 \mathrm{~m}$ of Stockton Formation in the Princeton no. 1 core being dominated 
WESTON \# $1 \& 2$
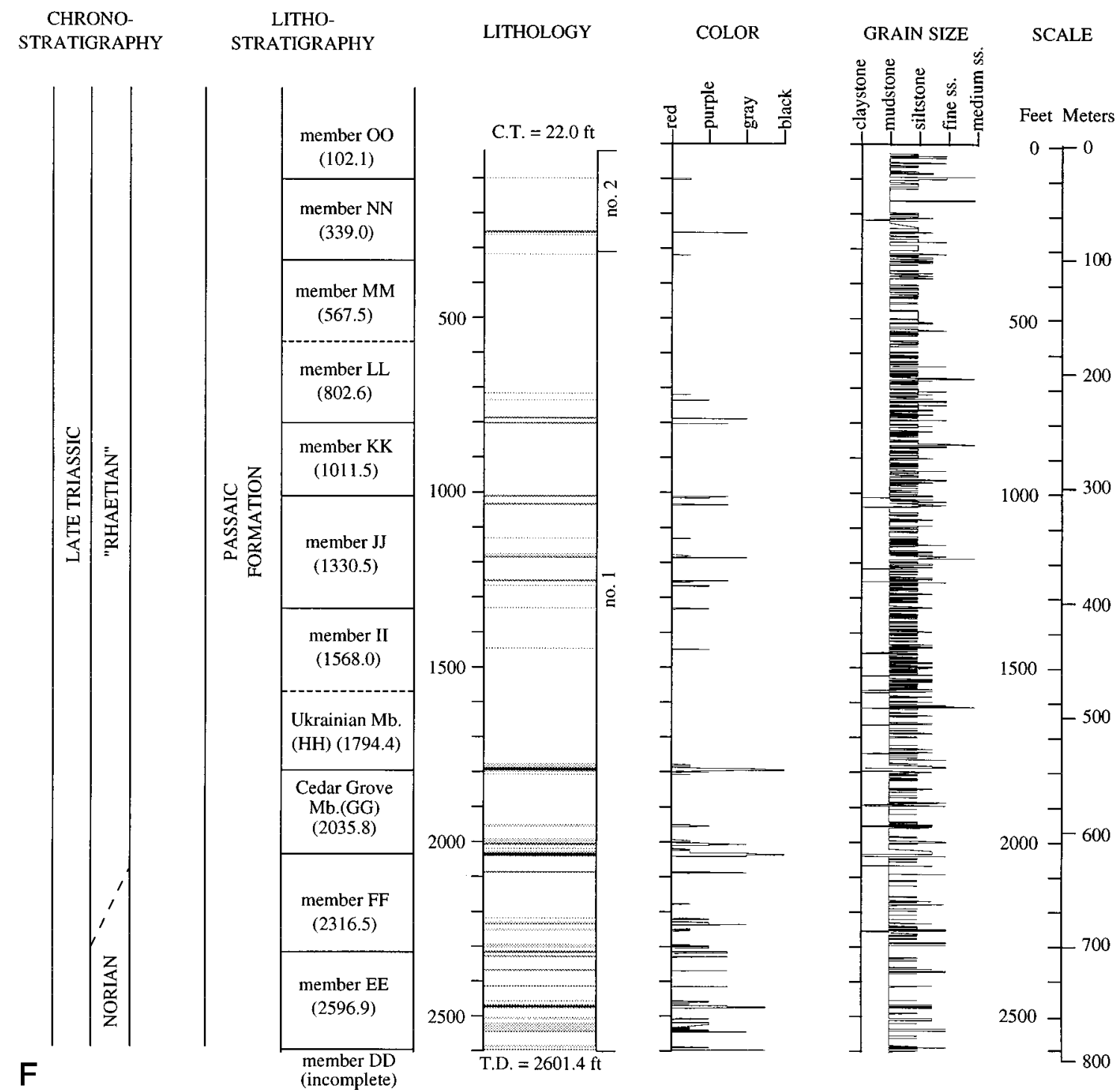

Figure 8. (Continued).

by red mudstone, as is true for the outcrop sections.

\section{Lockatong Formation}

Kümmel (1897) named the Lockatong Formation for the mostly gray and black massive and fissile mudstones that crop out in Lockatong Creek in the western fault block (2 in Fig. 2). The base of the Lockatong Formation is defined as the base of the lowest prominent black or gray shale unit, and its top is defined where red beds predominate over gray. The reference section for the type area is the New Jersey Route 29 exposures along the Delaware River
(Fig. 12). In his description of the type area of the Lockatong Formation, McLaughlin (1945) divided the upper part of the formation into a series of gray and black informal units (B, A2, A1) and gave informal names to the distinctive intervening red mudstone sequences (Fig. 11). These red gray couplets were subsequently given the informal member names of Walls Island, Tumble Falls, and Smith Corner, and the underlying four units of equal rank were named in descending order the Prahls Island, Tohickon, Skunk Hollow, and Byram members (Olsen, 1986). Below we formalize these members and provide type sections for each (Fig. 11). The remaining lower part of the Lockatong For- mation is very poorly exposed in the type area, and 5 members (Ewing Creek, Nursery, Princeton, Scudders Falls, and Wilburtha) are proposed, based on the NBCP cores. In total there are 12 members in the Lockatong Formation; the proposed new members of the Lockatong Formation, the origin of their names, their earlier informal synonyms, and locality data for the type sections are summarized in Table 2 and in data in the GSA Data Repository. ${ }^{1}$

${ }^{1}$ GSA Data Repository item 9601 is available on request from Documents Secretary, GSA, P.O. Box 9140, Boulder, CO 80301. 
MARTINSVILLE \# 1

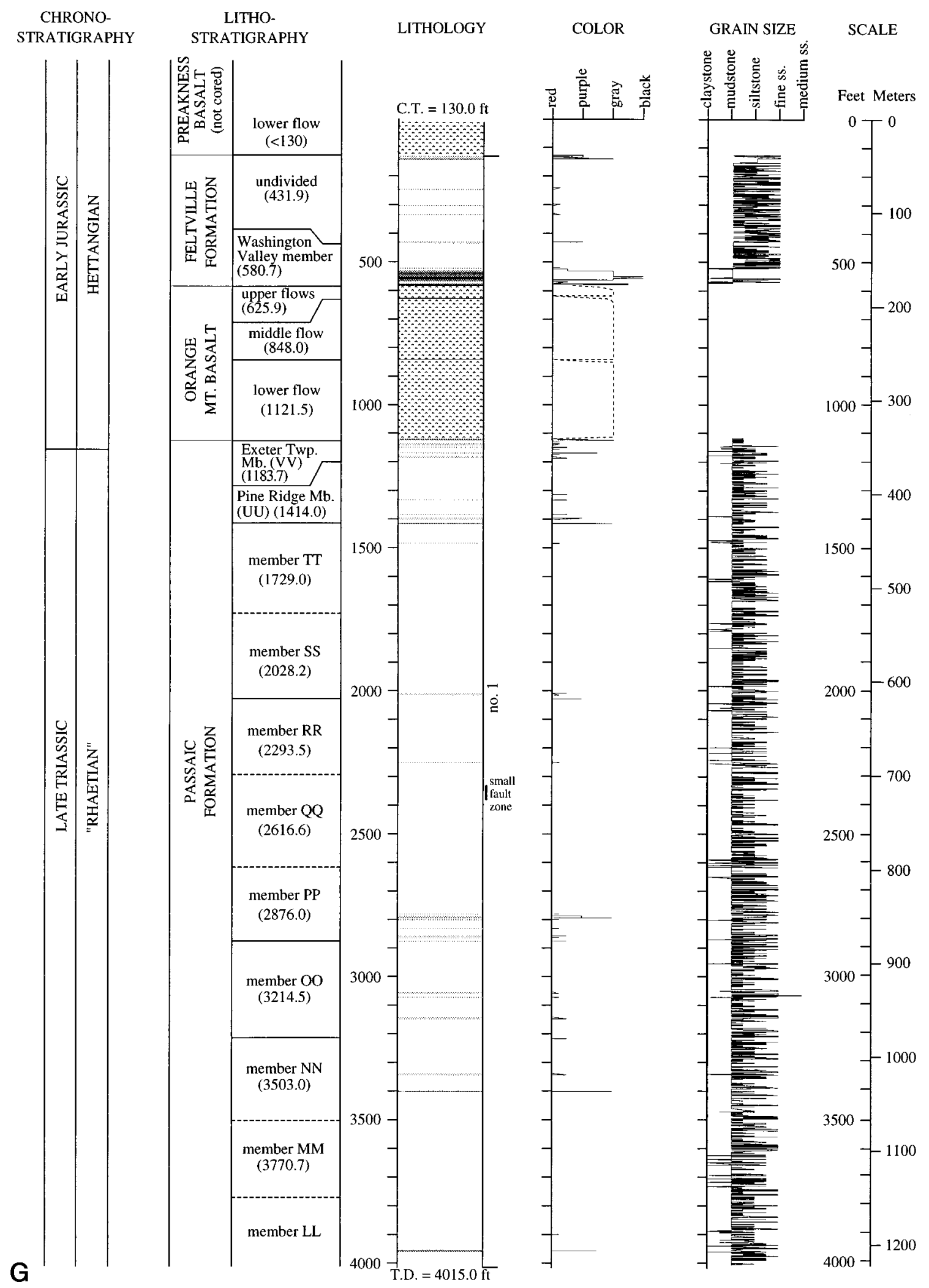

Figure 8. (Continued). 


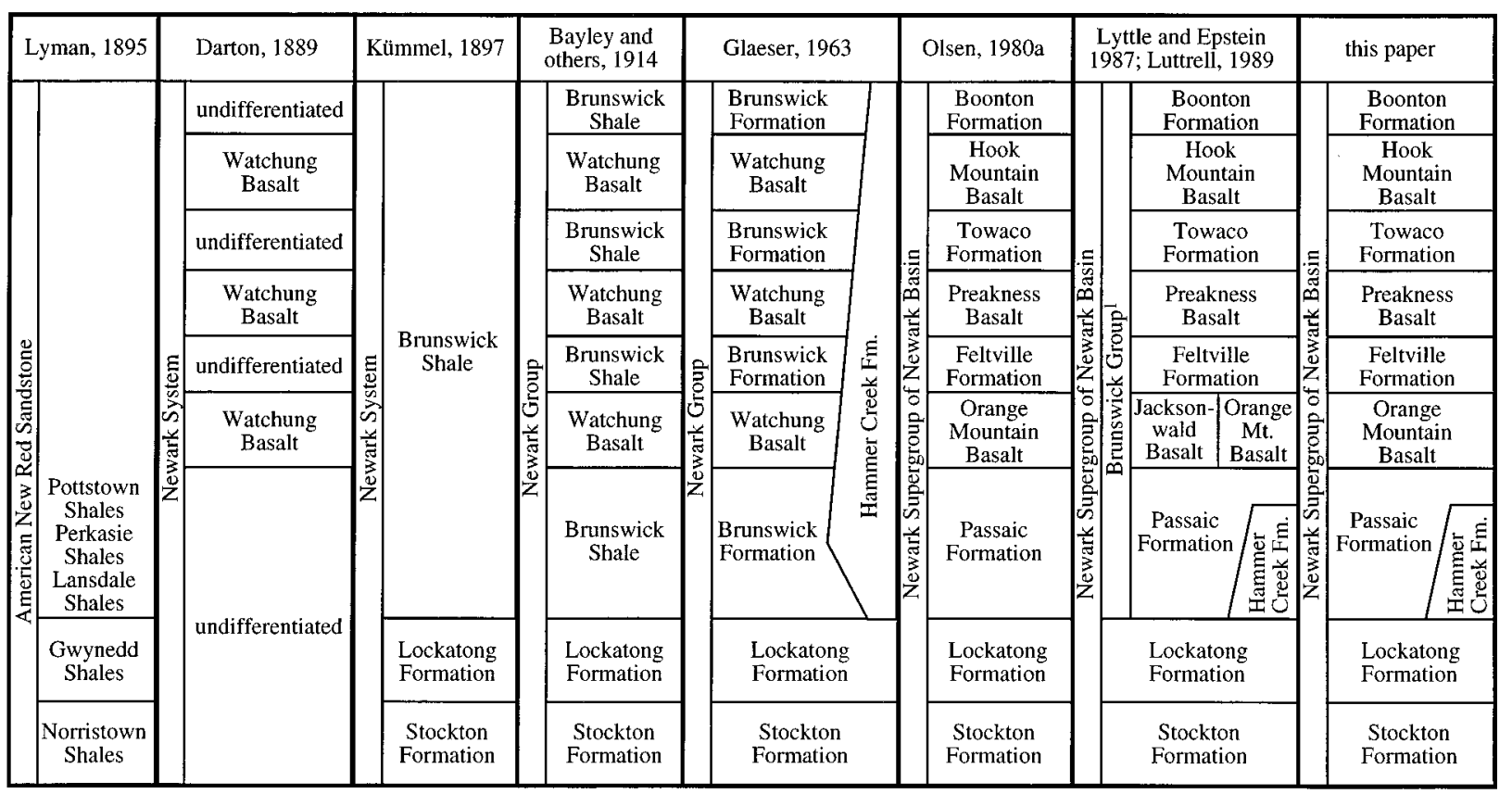

Figure 9. Formations of the Newark basin. Jacksonwald basalt appears in Pennsylvania only.

The Lockatong Formation occurs in all of the major fault blocks in the Newark basin. Its maximum thickness in the type area is about 1150 m (Fig. 12). Lockatong Formation is present in the Princeton no. 1 and no. 2 cores from $14.0 \mathrm{~m}$ (core top) to 254.2 $\mathrm{m}$, the Nursery core from $95.1 \mathrm{~m}$ (core top) to $968.7 \mathrm{~m}$, and the Titusville no. 1 core from $786.4 \mathrm{~m}$ to $924.9 \mathrm{~m}$ (T.D.). The boundary between the Lockatong and Passaic formations occurs at the gray to red transition of the Walls Island Member at $877.2 \mathrm{~m}$ (Figs. 8C and 12, and Fig. 17, below) in the Titusville no. 1 core.

Despite the considerable distance (about $40 \mathrm{~km}$ ) between the type area of the Lockatong Formation and the core sites (Fig. 2) and the fact that the two areas are in separate fault blocks, correlation has proved straightforward (Fig. 12). In general, the character of the cyclicity described at various outcrops by Van Houten (1964, 1969) and Olsen (1986) proves to be characteristic of the entire formation. The most noteworthy change between the NBCP cores and type area is the thickening of the correlative parts of the section toward the type area (Figs. 12 and 13), coupled with a disproportionate thickening of the gray and red massive mudstone intervals as seen in the Nursery and Ewing Creek members. Otherwise there is surprisingly little lithological change.
Correlative sections of the Princeton to Ewing Creek members in the Eureka-Gwynedd area are relatively expanded (Fig. 13) compared to the Princeton and Nursery cores. The red and gray massive mudcracked mudstones are expanded to a greater extent than the black shales, although they too increase in thickness. The Eureka-Gwynedd area is more centrally located in the basin than the coring sites, and a similar pattern of expansion characterizes the edge-to-center transitions seen in the rest of the Lockatong and Passaic formations (e.g., Silvestri and Schlische, 1992).

The basal three members of the Lockatong Formation-the Wilburtha, Scudders Falls, and Princeton members-are transitional from the underlying Stockton Formation and are characterized by large amounts of sandstone and irregularities in the thicknesses of Van Houten cycles (Fig. 14). The base of the Wilburtha Member defines the base of the Lockatong Formation. This boundary is drawn at the base of the lowest gray and black bed (254.2 $\mathrm{m}$ in the Princeton no. 1 and $938.3 \mathrm{~m}$ in the Nursery no. 1 cores) (Figs. 8A and 8B). Correlation of these three lower members of the Lockatong Formation with the type area is based largely on position (Fig. 12), because these units outcrop so poorly in the western fault block. Nonetheless, the silty and sandy character of the outcrops and the relatively high fre- quency of microlaminated black shales are consistent with this correlation.

Northeast of the Princeton area the Lockatong Formation and its components thin dramatically. This is best seen in the Nursery and Princeton members, which are well exposed below the Palisade sill in northeastern New Jersey (Fig. 13). This thinning is consistent with the latter area being closer to the hinged margin of the basin (Olsen, 1980a, 1988a) and the longitudinal end of the basin (Schlische, 1992).

Correlation between the outcrop type sections of the Byram, Skunk Hollow, and Tohickon members (Fig. 15), the Prahls Island (Fig. 16), and Smith Corner, Tumble Falls, and Walls Island members (Fig. 17) to the cores is based on the detailed match in lithological sequence and superposition of the members (Fig. 12). In all cases, correlative sections of the cores are thinner relative to the outcrop type sections.

Correlation Between Cores. The overlap zones between stratigraphically adjacent cores have proved crucial to making a composite of the successive core-hole records. They establish not only the scaling parameters used to produce the composite section, but also show the extent to which units can be correlated laterally. The lithological correlations are in all cases tested by the magnetic polarity stratigraphy, the terminology of which is from Kent et al. (1995). 


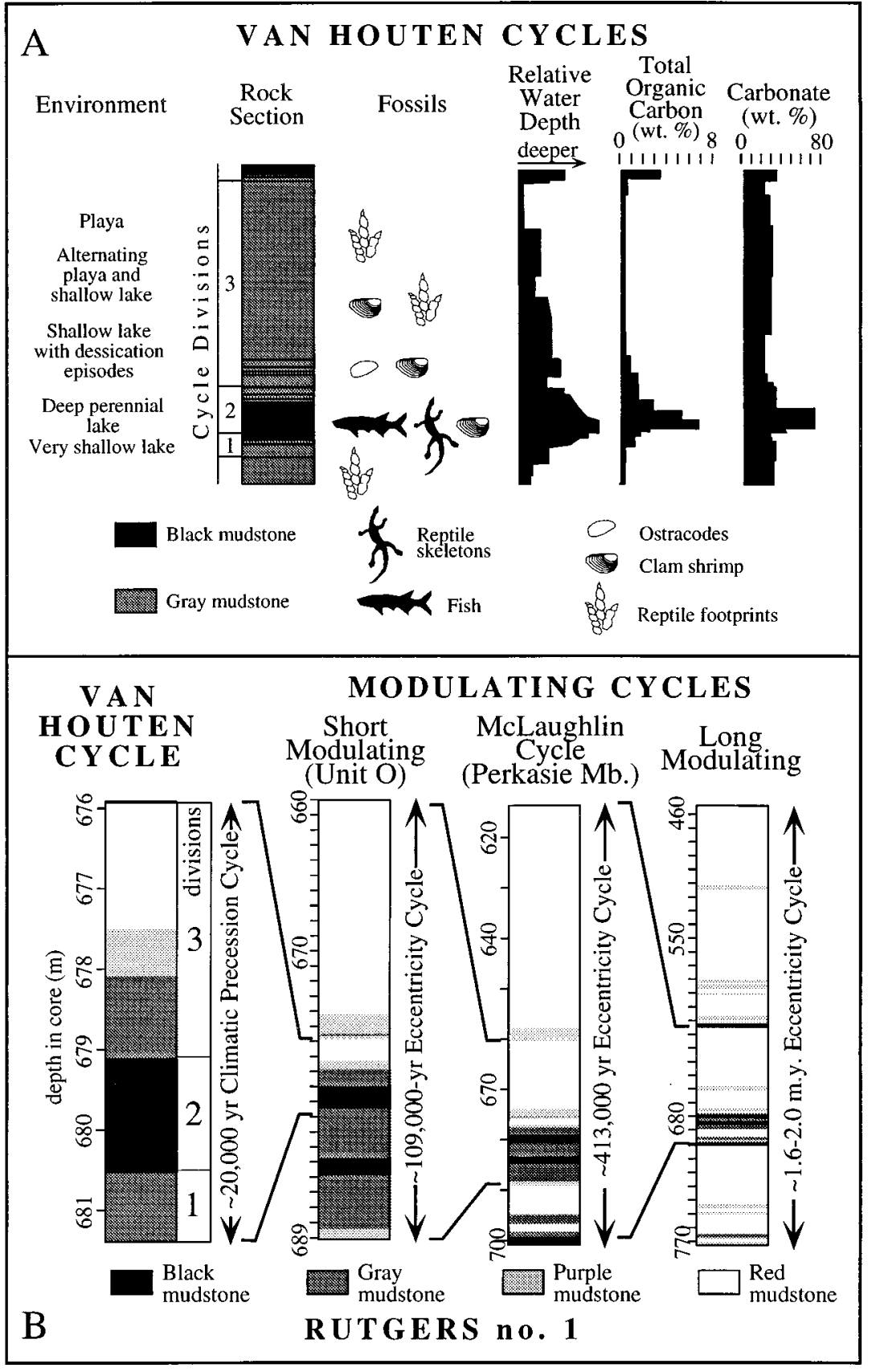

Figure 10. The four basic lacustrine cycle types of the Newark basin. A. The Van Houten cycle (example based on the cycle containing the Skunk Hollow fish bed in outcrop in the New Jersey Route 29 exposures at Byram, New Jersey; corresponds to cycle at $523 \mathrm{~m}$ in the Nursery no. 1 core). B. Van Houten and modulating cycles of the lacustrine rocks of the Newark basin showing the method of member designation based on the Perkasie Member as seen in the Rutgers no. 1 core (Fig. 8D).

Princeton and Nursery Core Overlap Zone. The transition from Stockton to Lockatong Formation is represented in the Princeton and Nursery cores by the Wilburtha, Scudders, Falls, and Princeton Members, and the lateral changes seen between these two cores are the largest seen in any of the ence between the relative position of the E10n polarity zone, which in both cores encompasses the lowest black shales in the Lockatong Formation and corresponds to the Lockatong-Stockton formational boundary (Fig. 14). The basal black shale of the Lockatong Formation in the Nursery no. 1 core are replaced by sandstone of the Stockton Formation in the Princeton no. 1 core. The change between these cores is best seen in the basal Princeton Member, which has several black shales in the E11n polarity zone in the Nursery no. 1 core but only one black shale in the corresponding portion of the Princeton no. 1 core (Fig. 14). Lithological correlation between the cores markedly improves from the middle of the Princeton Member upward, and the upper boundary of polarity zone E11n occurs in both cores in excellent agreement with a matching sequence of Van Houten cycles (Fig. 14). The details of lithology and cyclicity in the overlying Nursery and Ewing Creek members match very well between core holes.

Nursery and Titusville Core Overlap Zone. Correlation between the overlap zones of the Nursery no. 1 and Titusville no. 1 cores is straightforward. This overlap is in the Tumble Falls and Walls Island members in the upper Lockatong Formation (Fig. 17). The correlation is tested by the transition between the E12r and the E13n polarity zones. The only important change is a slight increase in the thickness of all of the units from the Nursery to the more down-dip Titusville core, along with a corresponding decrease in the frequency of red units.

The remarkably close matches between the cyclostratigraphy and magnetostratigraphy seen in the overlap zones and with outcrops is at the Van Houten scale of resolution. The proportional change in the cyclostratigraphic thicknesses between overlap zones is matched exactly (within sampling resolution) with the relative position of magnetic polarity zone boundaries. This indicates that within our sampling resolution, both the high-stand portions of Van Houten cycles (division 2) and the polarity boundaries themselves are isochronous horizons.

Vertical Trends. As seen in the cores and outcrops in the type area, the Lockatong Formation consists of a basal sand-rich portion made up of the Wilburtha, Scudders Falls, and Princeton members in which the Van Houten and modulating cycles vary erratically in thickness vertically and laterally. This is followed by an interval composed of 


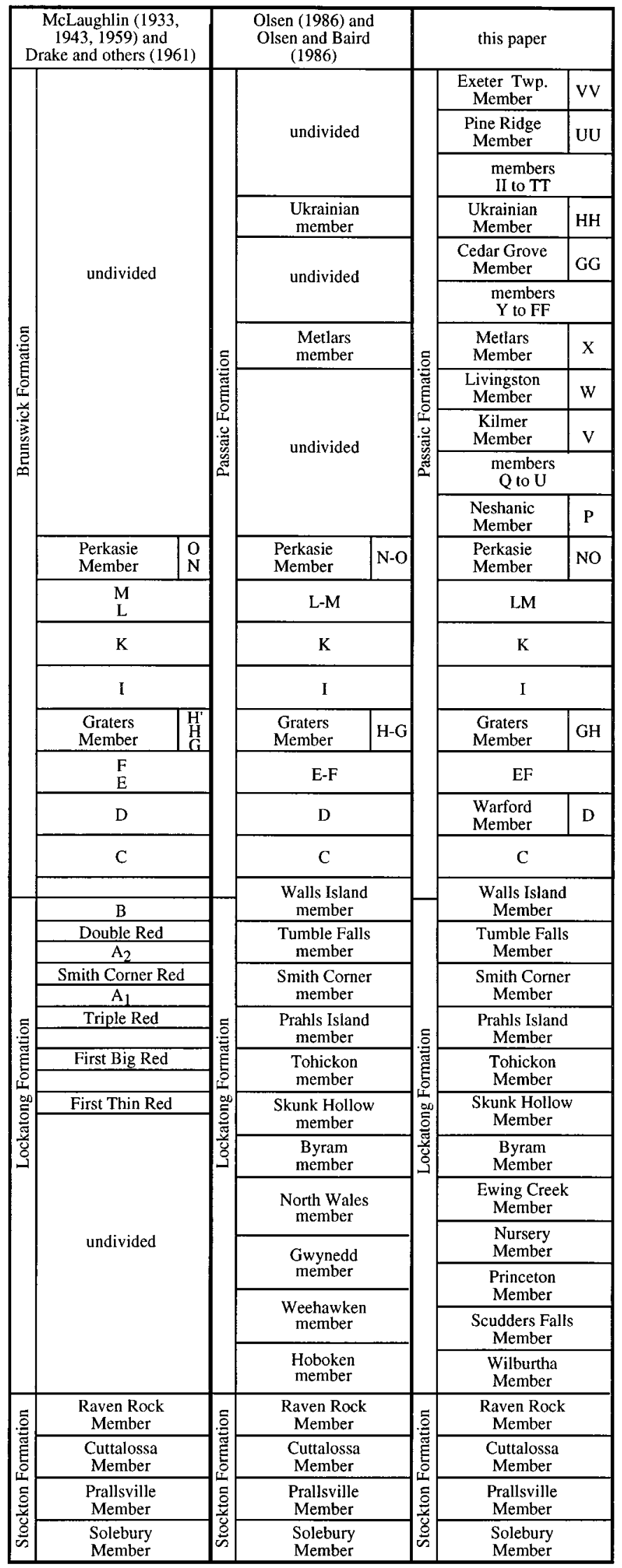

Figure 11. Members of the Stockton, Lockatong, and Passaic Formations. North Wales and Weehawken members of Olsen (1986) are equivalent to the Ewing Creek Member of this paper. Gwynedd and Hoboken members of Olsen (1986) are equivalent to the Princeton Member of this paper.

the Nursery and Ewing Creek members, rich in Van Houten cycles with thick black shales and little massive mudstone (Smoot and Olsen, 1994), in which the cycle thicknesses and lateral variations are much more regular, even though cycle thickness is low compared to the rest of the Lockatong Formation. The succeeding Byram, Skunk Hollow, Tohickon, Prahls Island, Smith Corner, Tumble Falls, and Walls Island members have a very consistent cyclostratigraphy both in the type area and in the cores. The increase in the frequency of red beds (through the middle and upper Lockatong Formation) presages the dominance of red beds in the overlying Passaic Formation.

In the cores, the Nursery and Ewing Creek members show an upward decrease in the frequency of bioturbation in gray and red mudstones and an increase in the frequency of densely mudcracked fabrics (breccia fabrics of Smoot, 1991) (Fig. 8). The abundance of mudcracked units increases upward into younger members in the cores. In the Eureka-Gwynedd area, however, sandstones become more abundant upward (Fig. 13).

Evaporite pseudomorphs are common in the upper parts of Van Houten cycles of the Lockatong Formation (Van Houten, 1964, 1969; El Tabakh and Schreiber, 1994; Smoot and Olsen, 1994). They are most common in Van Houten cycles with well-developed, but not microlaminated, black shales (Smoot and Olsen, 1994). This latter kind of Van Houten cycle increases in relative frequency upward in the Lockatong Formation. Red and purple Van Houten cycles, in contrast, have infrequent evaporite pseudomorphs (Smoot and Olsen, 1994). Because the frequency of red and purple cycles also increases upward in the Lockatong Formation, the overall frequency of evaporite pseudomorphs is highest in the upper middle part of the formation, then decreases in the upper part of the formation.

Like the underlying three members, the 


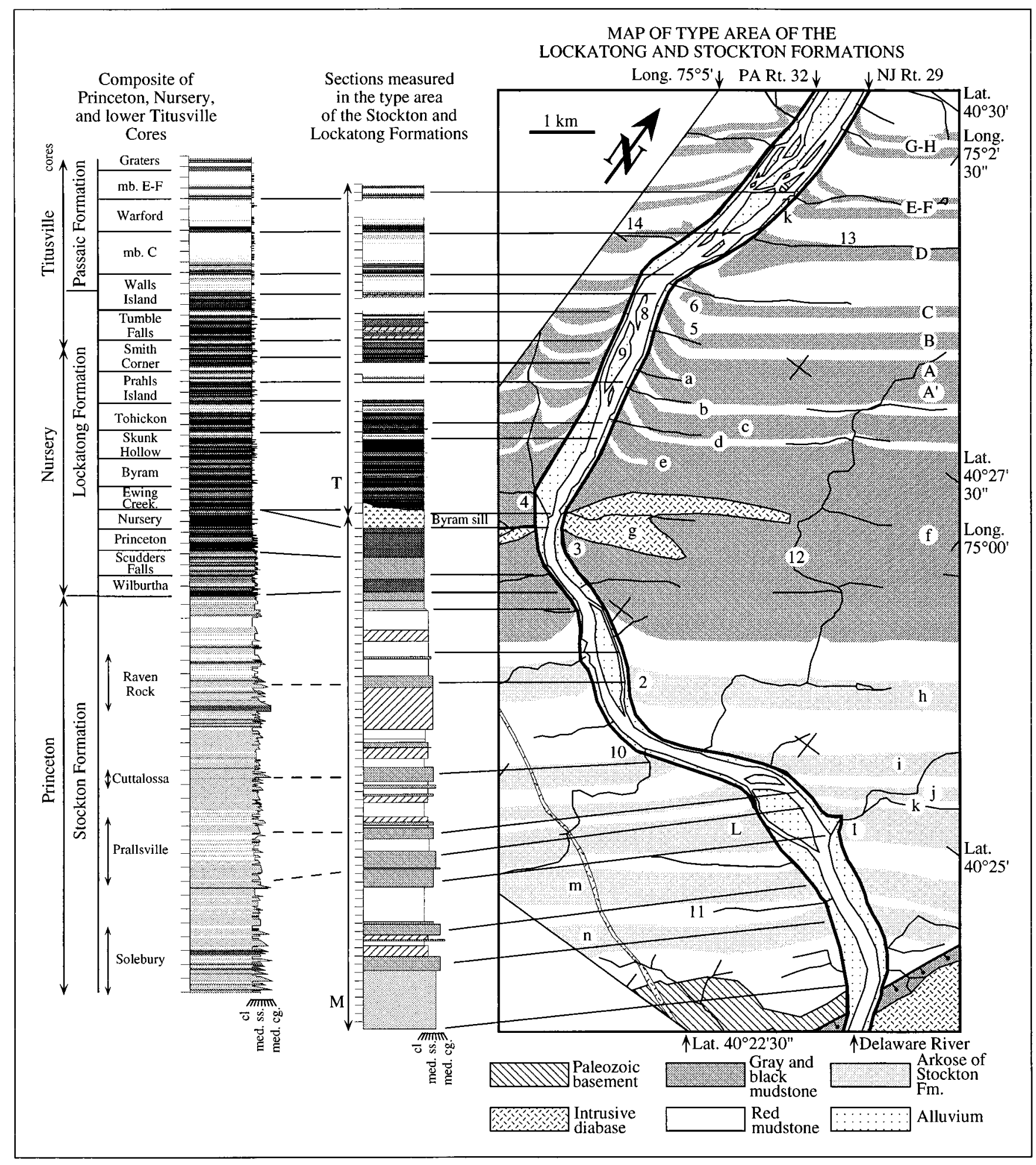


Figure 12. Type sections of the Stockton and Lockatong formations in the western fault block compared to the NBCP cores. Type area sections are designated by T, for the Lockatong and lower Passaic, and the section designated $M$ is compiled from measurements made by McLaughlin (1945). Letters A, $A^{\prime}, B, C, D, E-F$, and G-H are members of the upper Lockatong and lower Passaic formations of McLaughlin (1933, 1945, 1946a, 1946b, 1959). Other units of McLaughlin: a, Smith Corner Red; b, Triple Red; c, undifferentiated middle Lockatong; d, First Thick Red; e, First Thin Red; f, undifferentiated Lockatong; g, Byram sill; h, Raven Rock Member; i, Cutaloosa Member; j, upper Prallsville Member; k, middle Prallsville Member; L, lower Prallsville Member; m, Solebury Member (undifferentiated); n, Solebury Member (undifferentiated). PA, Pennsylvania; NJ, New Jersey. Locations are 1, Stockton, NJ; 2, Raven Rock, NJ; 3, Byram, NJ; 4, Point Pleasant, PA; 5, Tumble Falls, NJ; 6, Devils Tea Table; 7, Kingwood Station, NJ; 8, Walls Island (south); 9, Prahls Island; 10, location of Cutaloosa Inn; 11, Solebury, PA; 12, Lockatong Creek; 13, Warford Creek; 14, Smithtown Creek. Map of the type areas of the Lockatong and Stockton Formations is based on McLaughlin (1945, 1946a, 1946b, 1959). Scales on the type sections of members of the Stockton, Lockatong, and lower Passaic formations are in hundreds of feet based on outcrop. Key for lithology as in Figure 8B. Scales in the composite core section are in hundreds of feet and are based on the original core measurements. Note that the type sections and the core are almost exactly proportional to each other in thickness. Details of the correlations are shown in Figures 13-19.

Nursery Member is very fossiliferous. The specific dominant taxa (e.g., fish, reptiles, and crustaceans [see data in Olsen, 1988a]) are remarkably consistent laterally, as are many subtle lithological features such as the style of microlaminations, organic carbon content, and the specific sequences of thin beds (Olsen, 1980c, 1984a). Individual Van Houten cycles (such as those labeled W6W1, Fig. 13) retain their faunal and lithological identities for over $150 \mathrm{~km}$.

Overall, the lateral and vertical changes seen in the cores and outcrops of the lower Lockatong Formation suggest the interaction of fairly large-scale clinoform complexes along the edges of the basin with a remarkably flat interior of the basin. The expansion of the Scudders Falls Member and its inconsistent cyclostratigraphy in the Princeton No. 1 core compared to equivalent strata in the more basinward Nursery no. 1 core is consistent with deposition on the foreset portions of lake margin clinoforms. The stratigraphic interval consisting of the lower members of the Lockatong Formation has, in fact, been identified as containing clinoform reflectors in seismic sections (Reynolds, 1994).

The Lockatong Formation overlying the Ewing Creek Member consists of the Byram, Skunk Hollow, Tohickon, Prahls Island, Smith Corner, Tumble Falls, and Walls Island members, which are very similar to one another (Figs. 8 and 15-17). They tion, and we follow the scheme set up by McLaughlin's modified nomenclature. McLaughlin (1933, 1943, 1944) and Van Houten (1969) divided the lower Passaic into eight informal units, two of which (Graters and Perkasie Members) were also given formal member names. Parker and Houghton (1990) proposed that a formal member status be given to one more of these units (Neshanic Member; Fig. 11). The NBCP cores contain 33 more unit members in the Passaic Formation (Fig. 11). All are given informal letter designations and nine are given new formal member names (Fig. 11). In total, we recognize 41 units of member rank in the Passaic Formation of the cores, all of which have letter designations, and 12 of which also have formal member names.

Present in all the major fault blocks of the Newark basin, the Passaic Formation is the thickest and most widespread formation in the basin section. In the NBCP cores, the Passaic Formation is about $2700 \mathrm{~m}$ thick (scaled to Rutgers no. 1 and no. 2). In the central fault block and in the Jacksonwald syncline we estimate the Passaic Formation is at least $3500 \mathrm{~m}$ and $>4000 \mathrm{~m}$ thick, respectively. The upper Passaic Formation is not present in the western or southeastern fault blocks.

In the NBCP cores, the Passaic Formation occurs from 8.2 (core top) to 785.8 (bottom of Passaic) in Titusville no. 1 and 2 , through the entire Rutgers, Somerset, and Weston cores, and from $341.8 \mathrm{~m}$ (top of Passaic) to $1223.8 \mathrm{~m}$ (T.D.) in the Martinsville no. 1 core (Figs. 7 and 8 ).

The type section is a relatively coarse facies of the Passaic Formation (Olsen, 1980a). Correlation of this section is certain with the NBCP cores in a broad sense because the type section occurs between the Orange Mountain Basalt and the Lockatong Formation (Olsen, 1980a). Although detailed, member-by-member correlation between the type section of the Passaic Formation and the cores is not possible with available information; the three main outcrop sections that contain the type sections of the members of the Passaic Formation are correlative, in detail, with the cores. These sections are in (1) the western fault block (Fig. 2), (2) the central fault block (Fig. 5), (3) the New Brunswick to Bound Brook area in the eastern fault block (Fig. 4), and (4) the Jacksonwald syncline (Fig. 2).

The western fault block contains the type sections of the members established by 


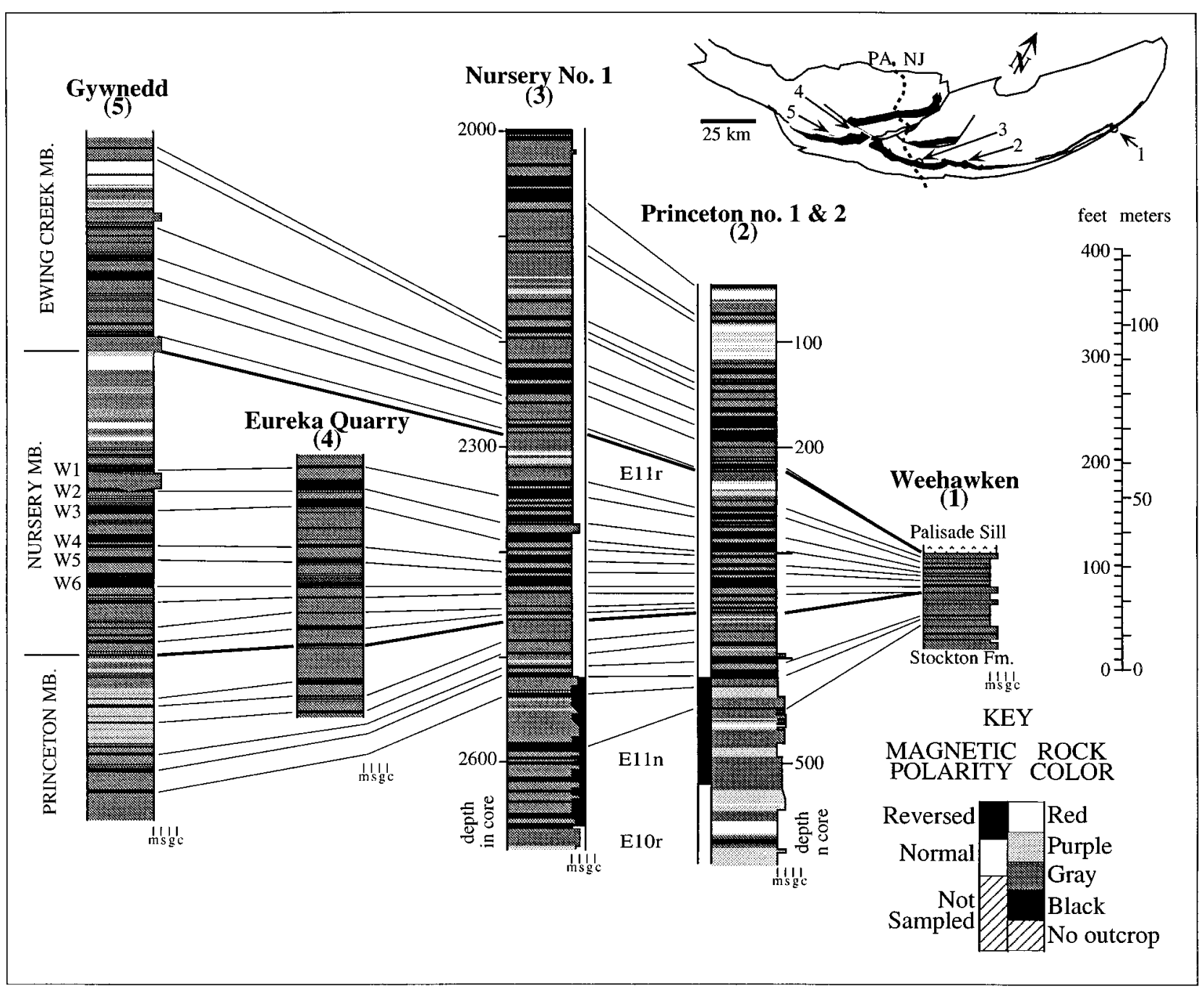

Figure 13. Lateral continuity in Princeton, Nursery, and Ewing Creek members. Note: The sections that formed the basis for the informal Hoboken and Weehawken members of Olsen $(1984 b$, 1986) are in the Kings Bluff, Weehawken, New Jersey, section (1) shown here; these two members prove to be synonymous with the Gwynned (Gwynedd I of Olsen, 1984b) and North Wales (Gwynedd II of Olsen, 1984b) members of Olsen (1986), the members originally based on the Gwynedd section (5). The formally named and defined Princeton and Nursery members are equivalent to the Hoboken and Gwynedd members and the Weehawken and North Wales members, respectively, which they also replace. PA, Pennsylvania; NJ, New Jersey; m, mudstone; s, sandstone; g, gravel; c, conglomerate.

McLaughlin (1933, 1943, 1944), as well as the newly named Warford Member (Figs. 11 and 18) in the lower Passaic Formation, and it is important to establish their correlation with the NBCP cores. McLaughlin never specifically designated type sections, although Lutrell (1989) subsequently named type sections for the formally named Graters (Fig. 19) and Perkasie (Figs. 20 and 21) members. We here designate and describe type sections for McLaughlin's informal members as well (Fig. 11). All of the formally named members of the Passaic Formation have surface type sections, as do McLaughlin's informal members. The new formal names are the Warford Member (Fig. 18), the Neshanic Member (Fig. 22), the Kilmer, Livingston, and Metlars members (Fig. 23), the Cedar Grove and Ukrainian members (Figs. 24 and 25), and the Pine Ridge and Exeter Township members (Fig. 26). Correlation with the cores of the surface type sections are corroborated by matching of the lithological sequences, usually in conjunction with magnetostratigraphic tests. Particularly well corroborated examples are the Perkasie, Ukrainian, and Exeter Township members, as described below. All of the other informal members of the Passaic Formation are designated in the
NBCP cores. Details of the origin of the names, exact locations and core depths of the type sections, and reference sections for all of the members are given in a table placed in the GSA Data Repository. ${ }^{2}$

Outcrops and exposures in the Jacksonwald syncline provide the type sections for the Pine Ridge and Exeter Township members, the uppermost divisions of the Passaic Formation (Figs. 8, 11, and 27). There is a major change in the expression of these members from the type sections to the cores,

\footnotetext{
${ }^{2}$ See footnote 1.
} 


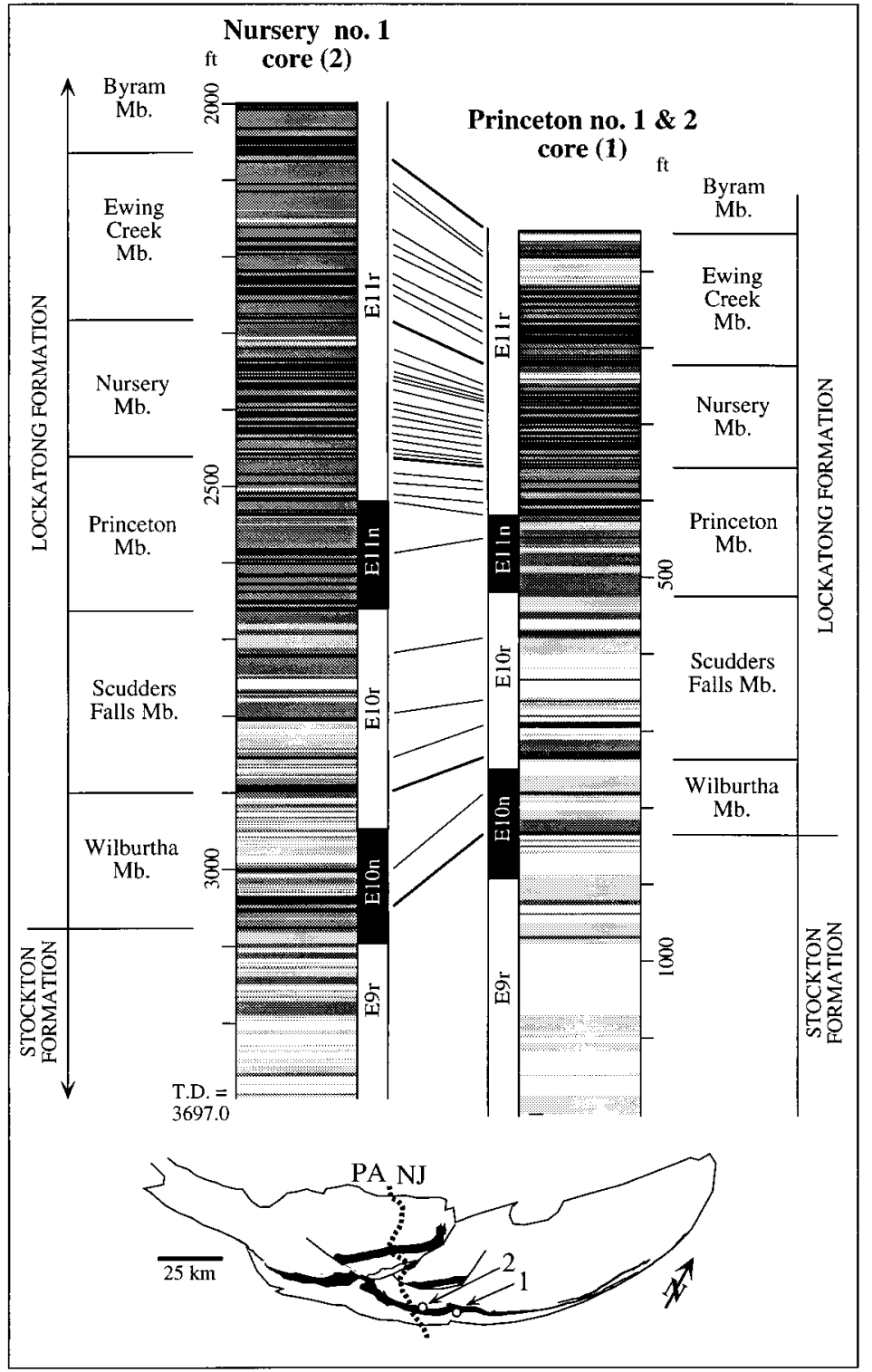

Figure 14. Overlap zones of the Princeton and Nursery cores. For lithology and magnetic polarity key see Figure 13. PA, Pennsylvania; NJ, New Jersey; T.D., total depth.

which is not surprising given that they are separated by over $110 \mathrm{~km}$ and are in different structural settings. However, correlation of the overlying Jacksonwald Basalt with the Orange Mountain Basalt, the magnetostratigraphy, as well as the overall lithostratigraphy and biostratigraphy (Smith, 1973; Fowell, 1993; Silvestri and Szajna, 1993) strongly suggests we have correctly identified these two members in the NBCP cores. The Exeter Township Member is unique in the upper Passaic Formation in that it is only a partial McLaughlin cycle. The cycle is truncated by the Orange Mountain Basalt (and equivalents), and the upper two-thirds of this McLaughlin cycle belongs to the overlying Feltville Formation.

Correlation Between Cores. Lateral changes and correlations in the Passaic Formation can be examined in more detail and over a larger area than in any other major division of the Newark basin. The four overlap zones between the NBCP cores and numerous good outcrops and exposures allow for the examination of many members of the Passaic Formation virtually basinwide.

Titusville and Rutgers Core Overlap Zone. The zone of stratigraphic overlap in the Titusville and Rutgers cores is the largest in the NBCP, covering nearly $280 \mathrm{~m}$ of section, encompassing all of members I, K, L-M, and the lower part of the Perkasie Member. This overlap is especially critical because these two cores are the most widely separated (42 $\mathrm{km}$ ) of the stratigraphically adjacent cores and are in different structural settings (Figs. 2, 4, and 5). A comparison of the overlap zones shows a close match in stratigraphy between the two cores that extends to the details of the component members and cycles (Fig. 21). This correlation is tested by the magnetic polarity stratigraphy in which the transition between polarity zones E14n and E14r occurs between the stratigraphically equivalent Van Houten cycles in the uppermost part of member L-M. Within sampling resolution $(\sim 3 \mathrm{~m})$, this polarity boundary has been identified at several other outcrops of member L-M and the Perkasie Member (Fig. 21). Correlation of these units laterally is thus strongly supported.

The most important lateral changes that can be seen in the overlap zone between the Titusville and Rutgers cores is a proportional thinning of the section, a decrease in "grayness" of constituent portions of the members, and a slight decrease in grain size in the Rutgers core relative to the Titusville core. The decrease in grayness in the Rutgers core is especially noticeable in the change of the color of division 2 of some of the most prominent Van Houten cycles in members I, K, and L-M from black in the Titusville core to purple in the Rutgers core. In addition several thin purple shales in the Titusville core are replaced by silt bands in the Rutgers cores. The slight decrease in grain size is largely due to a decrease in the frequency of silt bands in the Rutgers no. 1 and no. 2 cores.

Rutgers and Somerset Core Overlap Zones. The top of member T-U, the Kilmer, Livingston, and Metlars members, and most of member $\mathrm{Y}$ are present in the overlap zone between the Rutgers and Somerset cores. As might be expected from the relative proximity of the coring sites, the lithostratigraphic correlation between the cores at the Van Houten cycle level is clear and is tested by the magnetic polarity correlation, which matches at the level of sampling (Fig. 24). All cycles in the Somerset core are more strongly expressed than in the Rutgers core, consistent with its more basinward position (Figs. 2, 3, and 4) relative to the Rutgers core.

The Kilmer, Livingston, and Metlars members are the best known of the units in the overlap zone (Fig. 23). The Kilmer 


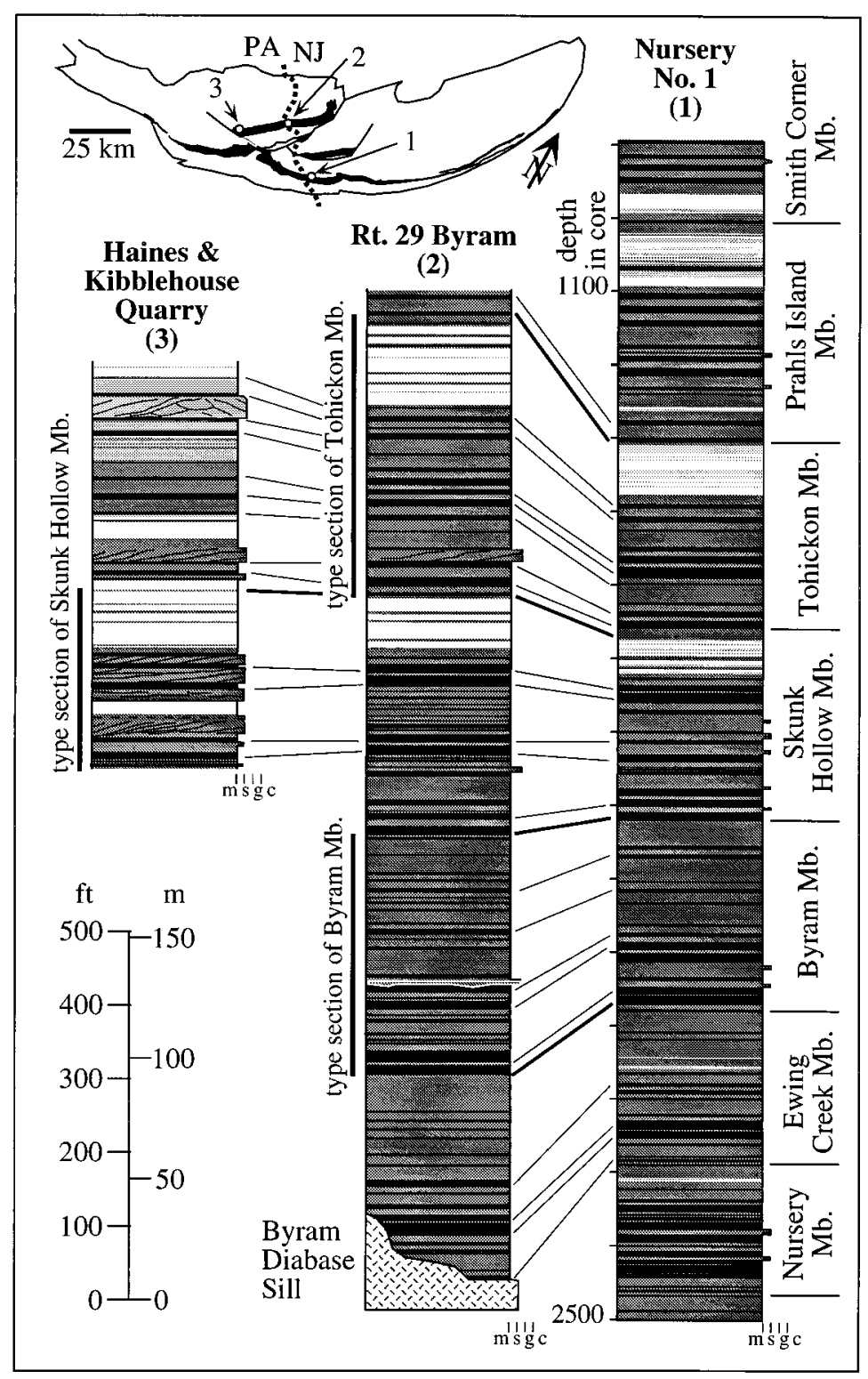

Figure 15. Comparison of Nursery No. 1 and exposures of the Lockatong Formation containing the type sections of the Byram and Tohickon members (along New Jersey Route 29 at Byram) and the type section of the Skunk Hollow Member in the Haines and Kibblehouse Quarry, Hilltown Township, Pennsylvania. For lithology key see Figure 13. PA, Pennsylvania; NJ, New Jersey; m, mudstone; s, sandstone; g, gravel; c, conglomerate.

Member is easily recognized by the disproportionate development of a single black shale above a very thick sequence devoid of black shales, or any well-developed Van Houten cycles (member T-U). Gray and black beds of the Kilmer Member are commonly copper mineralized, and their surface trace is often expressed by limited plant growth. The Livingston Member is the least distinctive of the three members, although it is unusual in having a dark gray shale in one Van Houten cycle in the third short modu- lating cycles. The Metlars Member is recognized by the pair of black shales in the middle short modulating cycle. The lower black shale-bearing Van Houten cycle in this short modulating cycle has a very well developed, often calcareous black shale, and the upper black shale-bearing Van Houten cycle tends to have well-developed granular evaporite pseudomorphs in the transition zone between divisions 2 and 3 .

The Kilmer, Livingston, and Metlars members have been traced in surface out- crops in the eastern part of the eastern fault block (Figs. 2 and 5). The degree of lateral change in this area is no greater than that seen between the Rutgers and Somerset cores. From the vicinity of the Rutgers core to Newark, no good outcrops of these three members are known. However, from Newark north to Hackensack, New Jersey, there is a prominent ridge with cyclical purple shale sequences in the proper stratigraphic position to be these members. A prominent purple shale is commonly overlain and underlain by white or purple sandstone near the base of the sequence. This unit occurs in outcrops and is present in a core (no. C-28) drilled by the Army Corps of Engineers during 1992 (ACE cores-see Fedosh and Smoot, 1988). It is locally intruded by a diabase sill and is locally copper mineralized. A string of copper mines, including the old Schuyler mine, was developed in this unit (Lewis, 1907). This copper-bearing unit is in the appropriate stratigraphic position to be the lower part of the Kilmer Member. As seen in the ACE cores, cyclical purple shales and sandstones in the succeeding McLaughlin cycle should represent the lower Livingston Member. As of this writing, ACE cores have not been recovered from the interval that should contain the Metlars Member. A slightly purple and red sequence does occur in the appropriate stratigraphic position to be part of the Metlars in the Passaic Formation type section along Interstate Route 80 in Hackensack, New Jersey (Olsen, 1980c).

Cyclicity of the Kilmer, Livingston, and Metlars members in the Newark to Hackensack area resembles that of the Passaic Formation above member JJ in the Weston and Martinsville cores, especially the dominance of ripple cross-laminated siltstones and fine sandstones that mark out most of the cyclicity; the best-developed Van Houten cycles are represented by purple shales and pale sandstones (Smoot and Olsen, 1994).

Somerset and Weston Core Overlap Zone. The overlap zone between the Somerset and Weston cores includes informal members $\mathrm{EE}$ and FF and the Cedar Grove and Ukrainian members (Fig. 25). Like the Rutgers and Somerset cores overlap zone, the lithostratigraphic match is clear and agrees with the polarity stratigraphy. The correlation demonstrates that the cyclicity in the Weston cores is slightly better developed than in the Somerset cores, with a slight proportional thickening from the former to the latter. These changes are consistent with the 


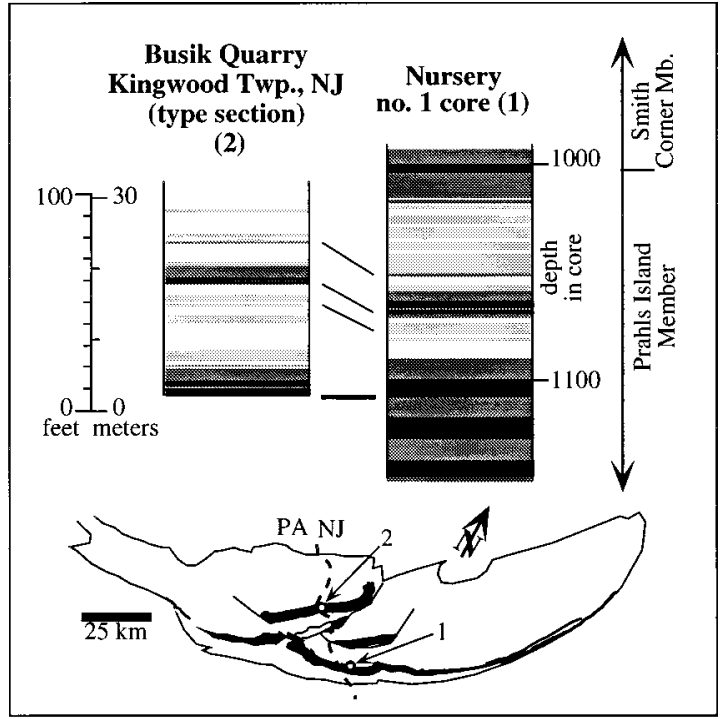

Figure 16. Type section of the Prahls Island Member compared to the correlative interval in the Nursery core. Section measured by Joseph Smoot and Bruce Simonson in 1994. For lithology polarity key see Figure 13. Twp., township; NJ, New Jersey.

fact that the Weston core hole is closer to the border fault than is the Somerset core hole. Because of the proximity of the Somerset and Weston core holes to the type sections of the Ukrainian and Cedar Grove members, the match to the surface outcrops is very good (Figs. 24 and 25).

Weston and Martinsville Core Overlap Zone. The overlap zone between the Weston and Martinsville cores contains part of member LL, all of members MM and NN, and part of member OO (Fig. 26). Typical Passaic Formation cyclicity is muted in this zone and through the rest of the Martinsville core, but lithostratigraphic correlation is still fairly clear and agrees with the polarity magnetostratigraphy. The Weston cores only capture the boundary between polarity zones E20r and E21n (Fig. 26). To be certain of the correlation, we examined outcrops adjacent to the Weston coring site for the overlying transition from E21n to E21r (Fig. 4). The transition is present about $18 \mathrm{~m}$ above the top of the Weston no. 1 core, in accord with our correlation with the Martinsville core. Poor outcrops immediately adjacent to the core hole site forced us to rely on a new paleomagnetic technique using chips collected around the bases of telephone poles (Witte and Kent, 1993).

The changes visible in correlative intervals from the Weston to Martinsville cores include a very slight increase in the expression of cyclicity and a slight proportional thickening. Very little is known at this time about lateral changes in this portion of the Passaic Formation outside of the NBCP cores, although it is quite likely that the thin gray shales and limestones in the homotaxial position within the Jacksonwald syncline represent the same members with an enhanced development of cyclicity.

Pine Ridge and Exeter Township Members. The uppermost two members of the Passaic Formation are the Pine Ridge and Exeter Township members (incorrectly cited as Exeter Member in Kent et. al, 1995), the type sections of which are in the Jacksonwald syncline (Fig. 2). These correlate with the upper Passaic Formation in the Martinsville no. 1 core (Fig. 27). Pine Ridge and Exeter Township members are important because they contain the latest Triassic-age strata and the Triassic-Jurassic boundary (Cornet, 1977; Smith et al., 1989; and see references in Fowell et al., 1994). In the Jacksonwald syncline, both members have gray and black shales and some limestones in well-expressed Van Houten cycles in the peaks of short modulating cycles in the lower parts of the members (McLaughlin cycles). The main change from the Jacksonwald syncline area is a marked decrease in the frequency and thickness of the gray beds in these cycles. The Oldwick syncline contains facies most similar to those in the Jacksonwald syncline. Gray zones correlative to the Exeter Township Member occur in this syncline, although they are injected with thin diabase intrusions. Palynological analysis confirms that the upper of these zones are Jurassic (Corollina-dominated and lacking Patinasporites) and the lower are Triassic (with abundant Patinasporites), consistent with identity as the Exeter Township Member (Fowell et al., 1994). Some very thin gray units survive in the Martinsville no. 1 core, in both the Pine Ridge and Exeter Township members. One gray unit in the Pine Ridge Member is better developed, however, and contains a palynoflorule of typical Triassic aspect (from $1430.8 \mathrm{~m}$ in Martinsville no. 1) (Fig. 27).

Correlations of the Triassic-Jurassic boundary and the divisions of the Exeter Township Member with the uppermost Passaic Formation in the Martinsville no. 1 core are corroborated by the occurrence of a very thin zone of reversed magnetic polarity (zone E23n.1r) surrounded by thick normal polarity intervals (E23.1n and E23.2n) (Fig. 27). This very short reversed zone occurs in proportionally the homotaxial position relative to the surrounding cyclical sequences and the basalt. Farther northeast from the Martinsville core site (Fig. 2), along the uppermost Passaic Formation outcrop belt, exposures are very poor. However, at one outcrop in Clifton, New Jersey (R. H. Hamilton quarry), there is a very local gray shale about $3 \mathrm{~m}$ below the Orange Mountain Basalt that contains a Jurassic (Corollina-dominated) palynoflorule and that is almost certainly part of the upper Exeter Township Member.

The Exeter Township Member is a critically important division of the Passaic Formation because it contains the palynologically identified Triassic-Jurassic boundary (Fowell, 1993; Fowell and Olsen, 1993). The drastic change in the pollen and spore assemblages described by Fowell (1993) through the middle Exeter Township Member is consistent with an environmental catastrophe. An alternative to this interpretation of the palynostratigraphy has been proposed by Van Veen (1995), who argued that there is a several million year hiatus at what has been identified as the TriassicJurassic boundary in the Newark basin. However, based on the strong similarity of both the lithological sequence and the detailed magnetostratigraphy within the Exeter Township Member at outcrops over 100 $\mathrm{km}$ apart, in different tectonic settings, we conclude that there is no physical evidence of a disconformity within the Exeter Township Member or at the lithological boundary of the contact with the Orange Mountain Basalt (or its equivalents). 


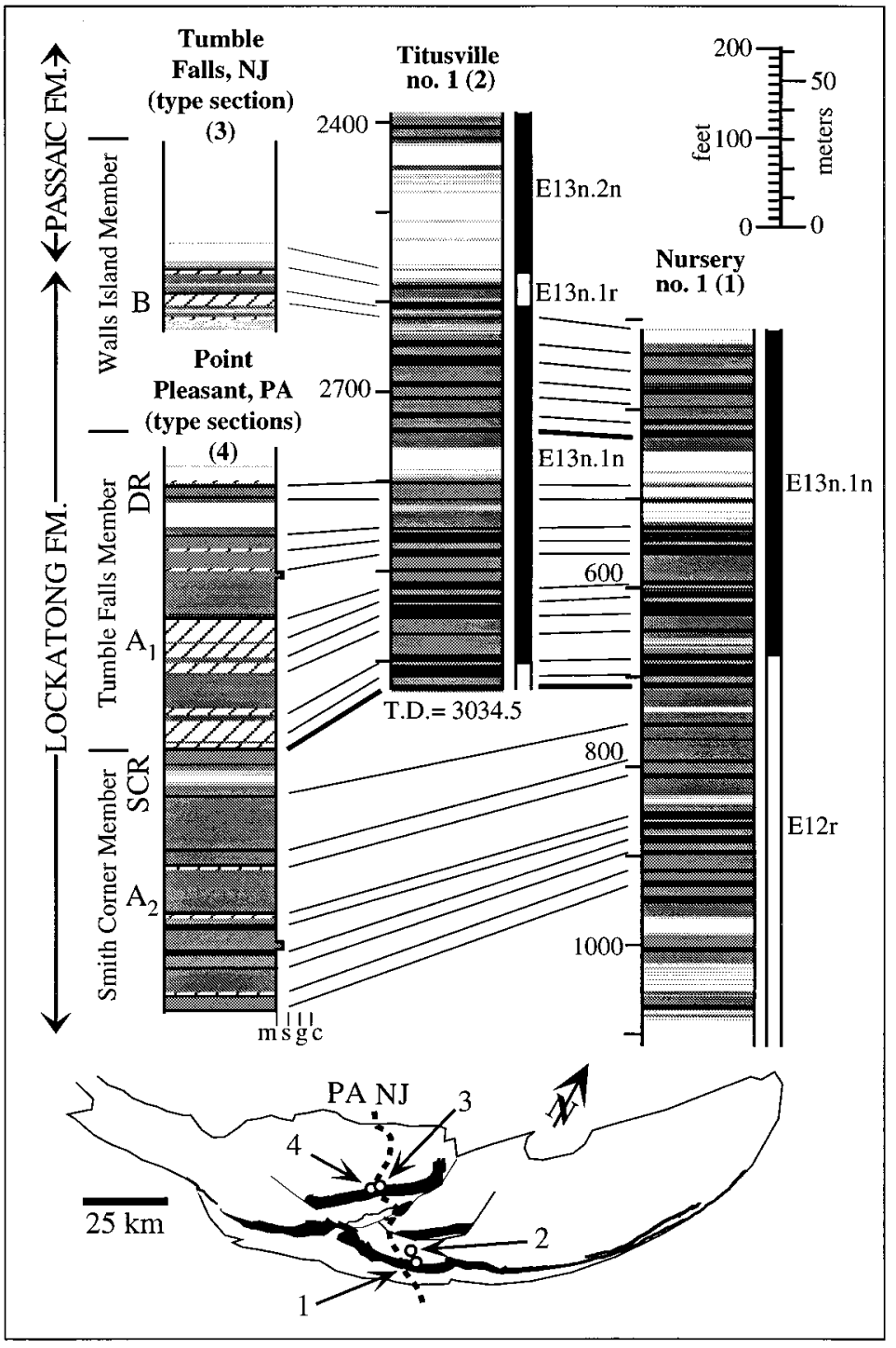

Figure 17. Overlap zone between Nursery and Titusville cores and the type sections Smith Corner, Tumble Falls, and Walls Island Members of the Lockatong Formation. $A_{2}, A_{1}$, and $B$ are informal designations of McLaughlin (1946a, 1946b); SCR and DR are McLaughlin's (1946a, 1946b) informal Smith Corner Red and Double Red, respectively. For lithology and magnetic polarity key see Figure 13. NJ, New Jersey; PA, Pennsylvania; T.D., total depth; m, mudstone; s, sandstone; g, gravel; c, conglomerate.

Vertical Trends. Three major vertical trends are evident through the Passaic Formation as seen in the NBCP cores: (1) an upward stepwise decrease in the frequency and thickness of gray and black units; (2) an upward decrease followed by an increase in grain size; and (3) an upward change from Van Houten cycles with vesicle-rich massive mudstone to cycles with rooted massive mudstone to rooted and burrowed massive mudstone interbedded with ripple crosslaminated siltstone and sandstone bands. All of these trends are superimposed on the continuing hierarchy of Van Houten and modulating cycles (Smoot and Olsen, 1994).

The upward increase in red color that characterizes the transition from Lockatong to Passaic formations continues up through the Passaic. This change occurs gradually in the lower Passaic Formation and then in steps in the middle and upper Passaic Formation. The lower stepwise increase is just above the Neshanic Member (Fig. 8 and Fig. 30, below) and the upper occurs just above the Ukrainian Member (Fig. 8 and Fig. 30, below). The latter step is especially noticeable because it occurs above a slight increase in the frequency of gray and black units and directly above one of the most prominent non-red units in the upper Passaic Formation, the Ukrainian Member (Fig. 8).

Siltstone and very fine-grained sandstone bands occur with decreasing frequency upward in the lower Passaic Formation. Commonly "silt curls" or thin ripple cross-laminated fine-grained sandstones are present. These occur cyclically, apparently as division 2 of very weakly developed Van Houten cycles in the "troughs" of modulating cycles (Olsen et al., 1994). The upward decreasing frequency of these units determines the upward-fining trends of the lower Passaic. The Passaic Formation is most fine grained in the NBCP cores between the Perkasie Member and member Y (Fig. 8).

Above member $\mathrm{Y}$, the frequency of silt and fine sandstone bands again increases, now with ripple cross-laminated fine sand being more common. Again these coarser beds seem to occur associated with, if not composing, division 2 of poorly expressed Van Houten cycles (cycle type V of Smoot and Olsen, 1994). Above the Ukrainian Member, they become, in fact, the most common expression of cyclicity. Interestingly, the upward increase in the frequency of these silt and fine sand units does not coincide with the stepwise decrease in the frequency of gray and black units (Fig. 8) but rather proceeds smoothly through it. The upward increase in the silt and sand beds produces the overall upward coarsening in the upper Passaic Formation.

The upward transitions seen in the Passaic Formation are at least partially true vertical (stratigraphic) changes, because all of the trends and steps are seen within the sequence of individual cores, not as differences between cores (Fig. 8 and Fig. 30, below). However, there is also an undoubted lateral component as shown by the change from mudstone-dominated Van Houten cycles with black shales in central Newark basin to sand- and silt-dominated cycles without black shales to the northeastern part of the basin in the Livingston and Kilmer members (Smoot and Olsen, 1994).

\section{Orange Mountain Basalt}

The Orange Mountain Basalt was named by Olsen (1980a) for the high-titanium, quartz-normative tholeiite basalt (Puffer et al., 1981; Tollo and Gottfried, 1992) above the Passaic Formation and below the 


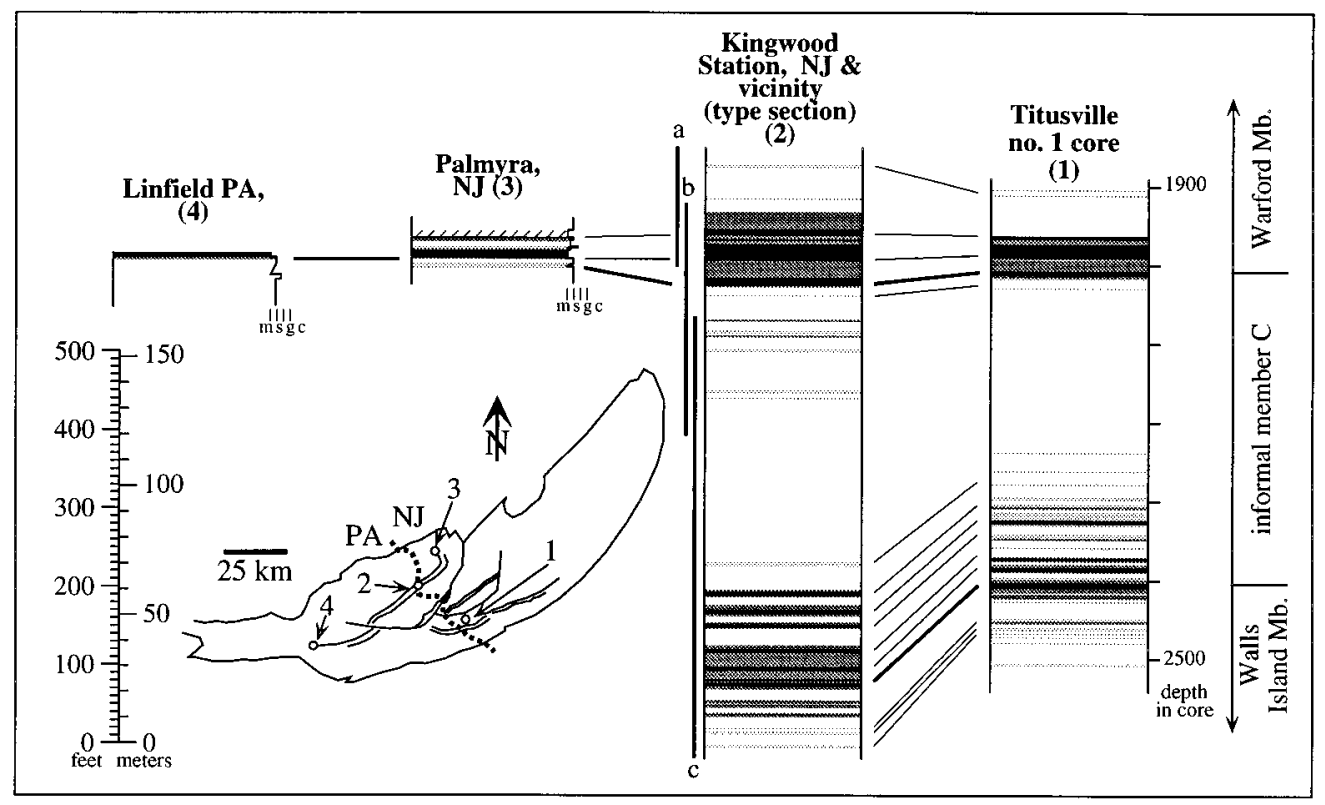

Figure 18. Member $\mathrm{C}$ and Warford Member of the Passaic Formation at the type and correlative sections. Section 2 is a composite based on a, the type section along Warford Brook; b, section along Smithtown Creek; c, section exposed along New Jersey Route 29, Kingwood Station, New Jersey. Section 3 is along tributary to Nishisakawick Creek, Palmyra, New Jersey; and section 4 along Longview Road, Linfield, Pennsylvania. For lithology key see Figure 13. PA, Pennsylvania; NJ, New Jersey; m, mudstone; s, sandstone; g, gravel; c, conglomerate.

Feltville Formation. The formation corresponds to the "1st" Watchung Basalt of Darton (1890). Three major flows are present in the Orange Mountain Basalt as seen in the NBCP cores (174.0-341.8 $\mathrm{m}$ in Martinsville no. 1) (Fig. 8). The two lower flows (flows 1 and 2) are subequal in thickness and the third is thinner. There are a series of thin flows associated with flow 3 in the cores as well as between flows 1 and 2 in some outcrops (Manspeizer, 1980).

The Orange Mountain Basalt is defined within the Watchung syncline of the eastern fault block. Equivalents include the Oldwick, Flemington, Sand Brook, and Jacksonwald basalts (Smith, 1973; Puffer, 1984; Ratcliffe, 1988). The distribution of the individual flows, other than the lowest, has not been determined outside the Watchung syncline. The type section of the Orange Mountain Basalt is the road cut through Orange Mountain along Interstate Route 280 in West Orange, New Jersey (Olsen, 1980a, $1980 \mathrm{~b})$. Orange Mountain is the local name for part of the more or less continuous cuesta of the First Watchung Mountain that connects the type section with the outcrop projection of the basalt flows encountered in the Martinsville no. 1 core. The two flows exposed in the type section probably corre-
Figure 19. Correlation of the type section of informal Member E-F and the Graters Member with Titusville no. 1 core. Divisions $E$ and $F$ and $G$, $H$, and $H^{\prime}$ are based on McLaughlin's (1933, 1946b) designations. For lithology see Figure 13. PA, Pennsylvania; NJ, New Jersey.

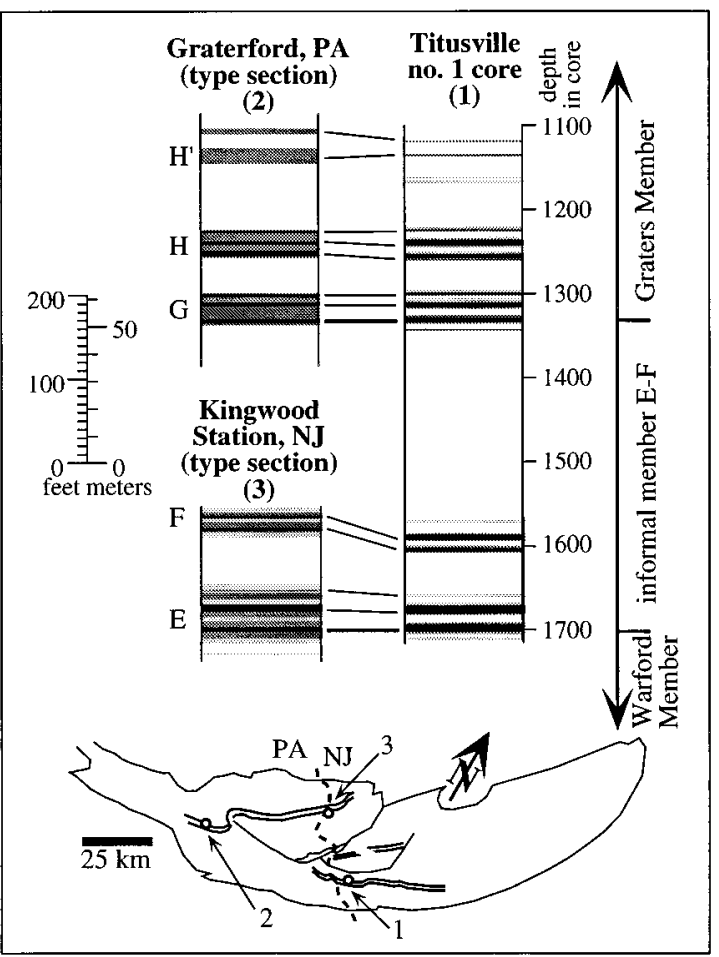




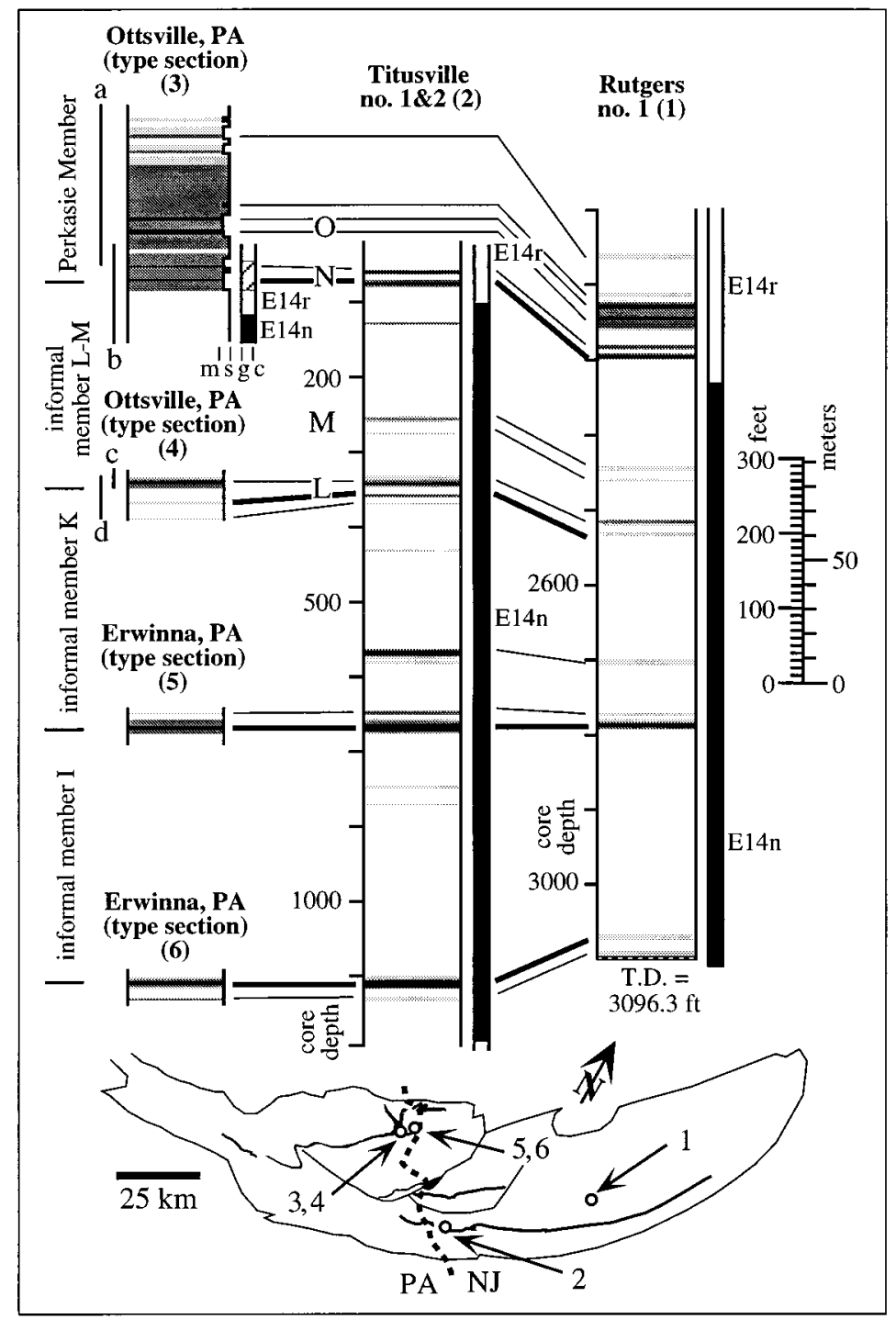

Figure 20. Overlap zone between Titusville and Rutgers cores and type sections of members I to L-M, and the Perkasie Member. Sections that make up the Ottsville section (3) are a, section in Bucks County Crushed Stone Quarry and adjacent Rapp Brook (the type section); b, section along Pennsylvania Route 611, Ottsville, Pennsylvania, polarity data from McIntosh et al. (1985) and Hargraves (personal commun.) (see Olsen, 1988a). Type section for member L-M is a composite: c, east side of Rapp Brook; d, west side of Rapp Brook. For lithology and magnetic polarity key see Figure 13. PA, Pennsylvania; NJ, New Jersey; m, mudstone; s, sandstone; g, gravel; c, conglomerate; T.D., total depth.

spond to the two lower flows in the Martinsville core.

\section{Feltville Formation}

Clastic and carbonate rocks above the Orange Mountain Basalt and below the Preakness Basalt were named the Feltville Formation by Olsen (1980a). The type section was described in part by Olsen (1980a, 1980c) and is described more fully here
(Fig. 28). The bulk of the Feltville Formation consists of ripple-cross-laminated red, purple, and gray sandstone, and red mudstone with subordinate amounts of cyclically occurring gray, black, and purple mudstone.

The Feltville Formation contains one informally named division, the mostly gray, informal Washington Valley member (Olsen, 1980a), which is of a lower rank than the members in the Passaic and Lockatong formations. The Washington Valley member is near the base of the formation and is made up of two prominent successive Van Houten cycles (Fig. 28) making up the largely gray portions of the lowest short modulating cycle of the formation. However, the thickness of these two Van Houten cycles is four to six times as great as those in the underlying formations, and each has a division 2 dominated by black gray or pink limestone. These two unusually limestone-rich cycles were described by Olsen (1980c), but they were mistakenly believed to be the same unit, because they were not seen in superposition. That two cycles are present became obvious only with the initial description of the first series of ACE cores (Fedosh and Smoot, 1988). The pattern was subsequently confirmed in outcrop by more persistent field work at the type section and elsewhere (Fig. 28). Gray sandstone and gray and purple mudstone also occur in the uppermost Feltville Formation and we believe these to be one or two poorly expressed Van Houten cycles. In total, the Feltville formation consists of the upper three-quarters of a McLaughlin cycle, the basal quarter of which is the Exeter Township Member of the Passaic Formation.

The Feltville Formation was defined in the Watchung syncline and is recognized in the Oldwick, Flemington, Sand Brook, and Jacksonwald synclines (Smith, 1973; Puffer, 1984). It may also be present in the Ladentown (Ratcliffe, 1988) and Flemington (Houghton et al., 1992) synclines (Fig. 2). The upper Feltville Formation becomes conglomeratic adjacent to the border fault at Oakland, New Jersey, and in the Oldwick and Jacksonwald synclines (Manspeizer, 1980; Olsen, 1980a, 1980b).

In the Martinsville no. 1 core, the Feltville Formation occurs from 39.6 to $176.8 \mathrm{~m}$. The overlying Preakness Basalt was not encountered in drilling, although it is exposed at the drill site, and therefore, some of the uppermost Feltville may not have been cored.

Correlation of the type section with the Martinsville core is clear by lithological criteria; although because the entire post-Passaic section is apparently of normal polarity (McIntosh et al., 1985; Witte and Kent, 1990; Witte et al., 1991), the correlation cannot be tested in detail by paleomagnetic criteria. The two Van Houten cycles of the Washington Valley member have been traced from the ACE cores at Paterson, New Jersey (Fedosh and Smoot, 1988), southwest through the Watchung syncline via outcrops to the Martinsville no. 1 core, to the old Pluckemin copper mine (Lewis, 


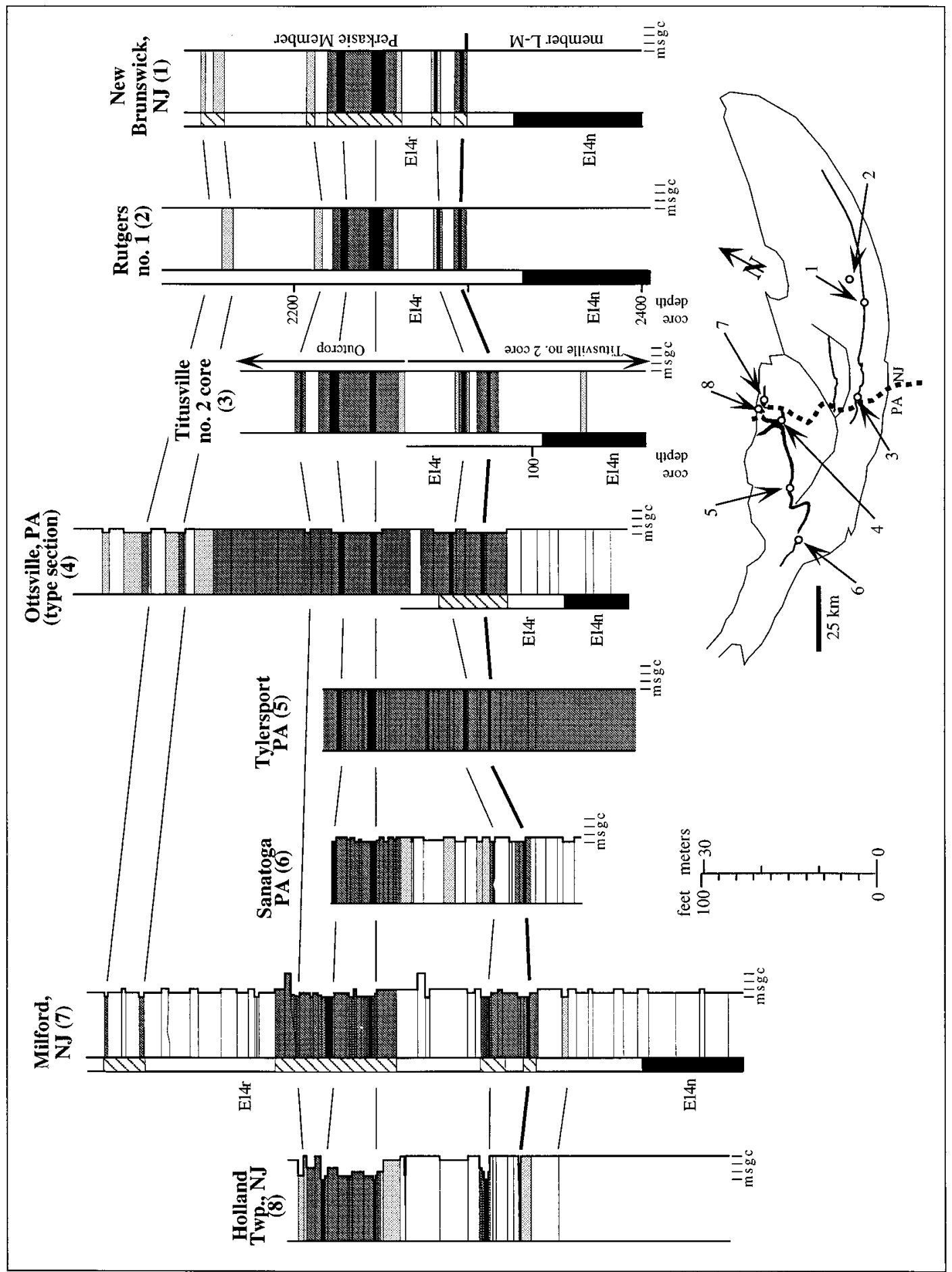

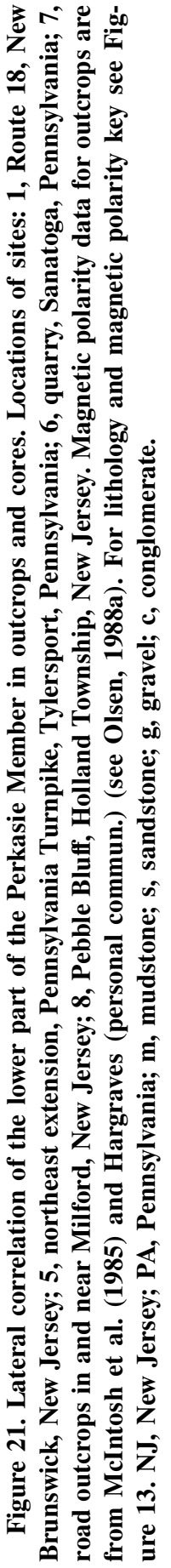



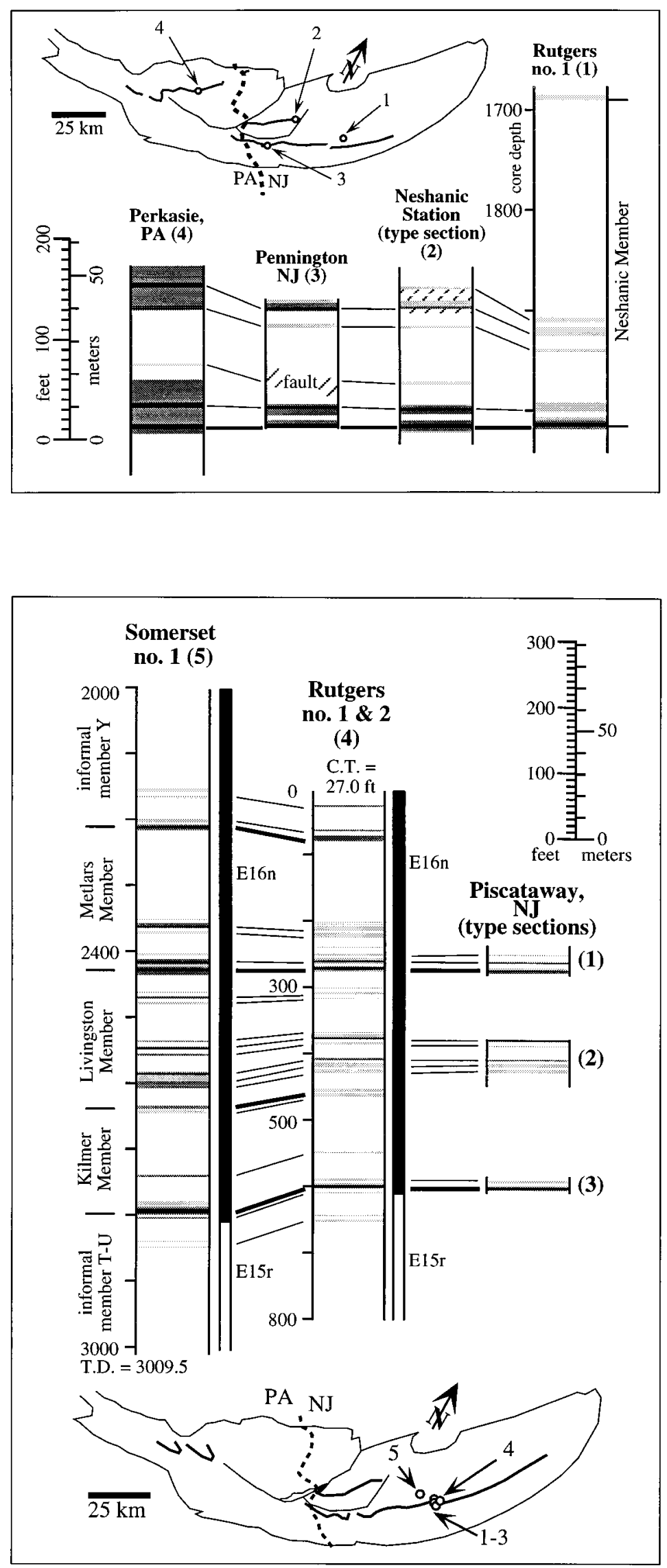

Figure 22. Lateral correlation of the Neshanic Member from its type area (Neshanic Station area) in the central fault block to the southeastern fault block and the Rutgers no. 1 core in the eastern fault block. For lithology key see Figure 13. PA, Pennsylvania; NJ, New Jersey.

1907) at the western terminus of the syncline. They have been identified in the Oldwick syncline, but they have not yet been found in the Sand Brook, Flemington, or Jacksonwald synclines, perhaps because of poor outcrop. The thickness of the lower cycle of the pair varies considerably along the irregular upper surface of the Orange Mountain basalt in the Watchung syncline. The main lateral facies changes seen in these cycles is variability in the degree of lamination (finely to crudely laminated) and color (black to pink) of division 2 of the cycles (Fig. 28). In addition, both clastic content and thickness of the cycles, especially division 2, increases greatly in the Oldwick syncline adjacent to the border fault system of the basin.

\section{Post-Feltville Formations}

Strata above the Feltville were not cored by the NBCP, but all of these formations have been sampled in the ACE cores (Fedosh and Smoot, 1988). In ascending order, the ACE core cover the complete Orange Mountain Basalt, Feltville Formation, Preakness Basalt, Towaco Formation, and Hook Mountain Basalt, as well as the lower third of the Boonton Formation. The Towaco and Boonton Formation are strikingly cyclical, with the same basic hierarchy of the underlying Feltville, Passaic, and Lockatong formations. Van Houten cycle thickness, however, is much expanded ( 20-25 m; Olsen et al., 1989; Schlische and Olsen, 1990). The Preakness and Hook

Figure 23. Overlap zone between Rutgers and Somerset cores and type sections of the Kilmer, Livingston, and Metlars members in Piscataway, New Jersey. For lithology and magnetic polarity key see Figure 13. PA, Pennsylvania; NJ, New Jersey; C.T., core top; T.D., total depth. 


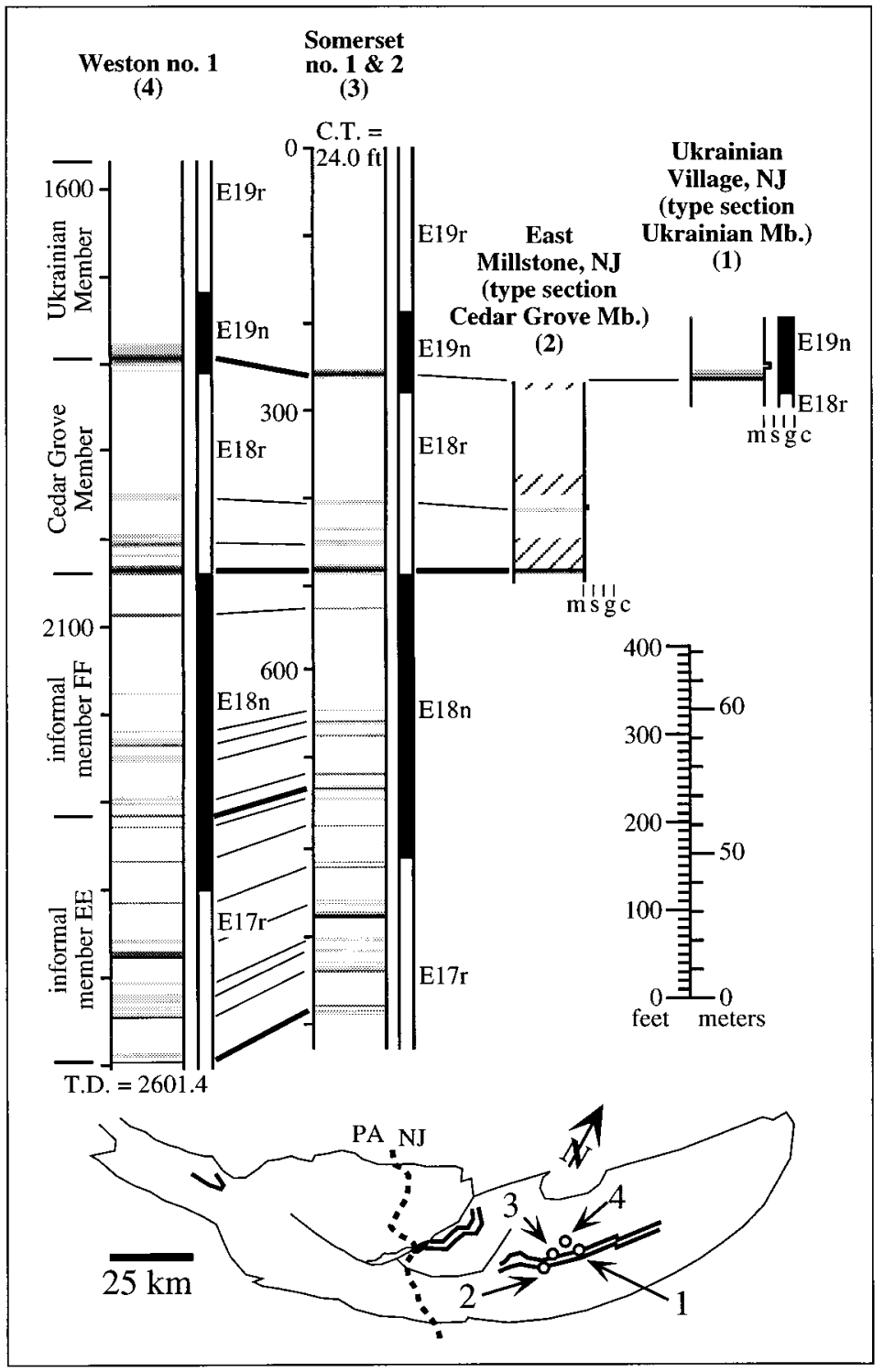

Figure 24. Overlap zones between Somerset and Weston cores and the type sections of the Cedar Grove (East Millstone section) and Ukrainian (Ukrainian Village section) members. For lithology and magnetic polarity key see Figure 13. NJ, New Jersey; PA, Pennsylvania; m, mudstone; s, sandstone; g, gravel; c, conglomerate; C.T., core top; T.D., total depth.

Mountain basalts are quartz normative tholeiites, like the Orange Mountain Basalt, and they are described in detail by Faust (1978), Manspeizer (1980), Puffer and Student (1992), and Tollo and Gottfried (1992). The details of the stratigraphy and cyclicity of these post-Passaic formations in the ACE cores will be described elsewhere.

\section{COMPOSITE SECTION}

The overlap zones between stratigraphically adjacent NBCP cores allow for the de- velopment of a composite section for the Newark basin. Production of this composite section for the NBCP cores required five steps.

1. The core logs from core no. 1 and core no. 2 were patched together in the cases where a short $(91 \mathrm{~m})$ core no. 2 was taken (Weston, Somerset, Rutgers, Titusville, and Princeton cores). This was accomplished by using at least one lithologically distinctive bed shared between cores.

2. We corrected core depth to stratigraphic depth by using distinctive peaks (usually shales) in the Amoco on-site core natural gamma logs and down hole gamma logs (Goldberg et al., 1994) to correlate the core to the core hole. The depth scale of the cores was then modified to conform to the depth scale of the hole. This procedure was necessary because of the inevitable expansion of the core and small amounts of core loss during the coring and retrieval process. Hole depth was then converted to true depth using hole deviation surveys, and true depth was converted to stratigraphic depth using the dip meter survey. In the case of the Weston cores, thin, distinctive shale beds in the core were directly correlated to natural gamma spikes in the hole logs because the SHADS system was not available. The amount of modification to the core depth is in all cases small, amounting to a maximum of $0.7 \%$ (Princeton cores) and averaging $0.5 \%$.

3. We selected correlation tie points for the overlap zones of stratigraphically adjacent core holes. These tie points are the bases of distinctive shales within division 2 of Van Houten cycles in the lower parts of the members of the Lockatong and Passaic formations. The slope of the correlation line for the tie points was determined using least squares regression (Fig. 29). The slopes of the regression lines are the scaling factors, or proportionality constants, between stratigraphically adjacent cores.

4. We selected the Rutgers no. 1 and no. 2 cores as a standard to which all of the cores were scaled. These cores have the greatest overlap with adjacent cores and have about average Van Houten cycle thickness (4 m, Olsen and Kent, 1995). Stratigraphically adjacent cores were scaled to each other by using the scaling factors, beginning at the Rutgers overlap zones, and proceeding up and down section.

5. Stratigraphically adjacent core records were then patched together at specific distinctive tie points with the down-the-dip portion of the overlap record given preference (e.g., Somerset portion of the Somerset-Rutgers overlap).

The composite stratigraphic section has a total thickness of $4660 \mathrm{~m}$ as it might appear if the whole section had been cored at the position of the Rutgers site had erosion not removed the overlying sequence (Fig. 30). Were the Titusville core selected as the standard, the total composite thickness would be $5926 \mathrm{~m}$. With the Preakness, Towaco, and Boonton Formations based on the ACE cores added, the total Newark basin section would be about 5400 m (based on a Rutgers 


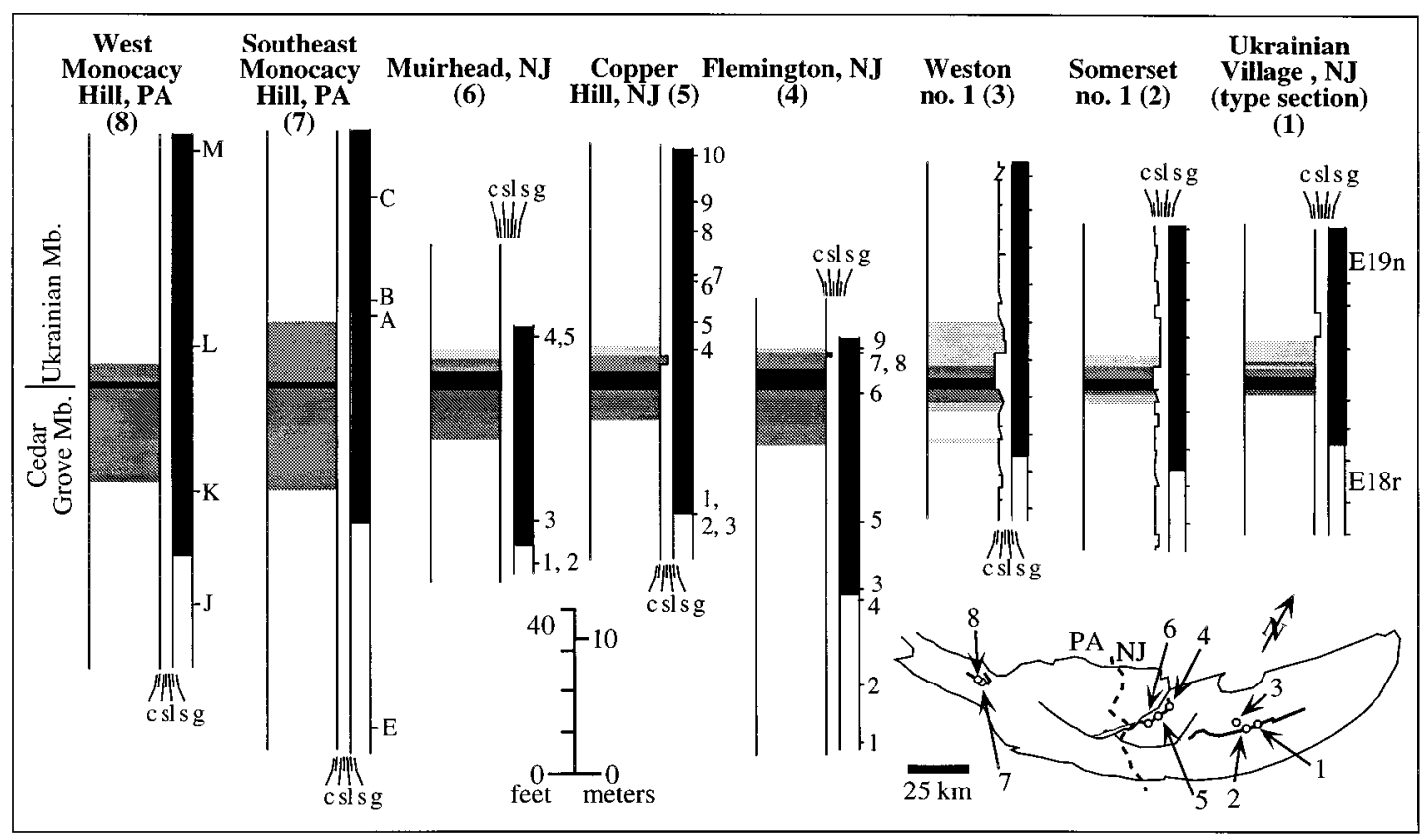

Figure 25. Lateral correlation of the basal Ukrainian Member from its type area in the eastern fault block (section 1) and cores (sections 2 and 3 ) to three sections in the central fault block and Jacksonwald syncline. For map details of the later three localities, see Figure 6. Ticks on right-hand side of the magnetic polarity sequence show sample levels and numbers. PA, Pennsylvania; NJ, New Jersey; c, claystone; sl, siltstone; s, sandstone; g, gravel; C.T., core top; T.D., total depth.

standard) or $6850 \mathrm{~m}$ (based on a Titusville standard). These thicknesses are comparable to Kümmel's (1897) upper estimates of from about 5300 to $6200 \mathrm{~m}$, which have generally been regarded as overestimated due to unseen normal faults.

Color and grain size show systematic variation in the composite. Purple, gray, and black colors dominate the lower half of the composite, whereas red beds dominate the upper half. Grain size is highest in the Stockton and lowest in the middle Passaic, increasing again through the upper Passaic and into the Jurassic age strata. This trend could be interpreted as the sole result of the relative proximity of the oldest and youngest cores to the basin edges. However, parts of the trend can be seen in the depth dimension in each of the cores, and there is very little grain size change seen in correlative zones between core holes.

Perhaps the most obvious feature of the composite section is the permeating cyclicity visible as color changes. At the scale shown in Figure 28, the most obvious cyclicity is the McLaughlin cycle and the long modulating cycle. The latter is most obvious in the middle and upper Passaic Formation. As seen in the compilation, the maximum variation in thickness of the members is roughly a factor of 1.5 (Wilburtha Member vs. member C).
Members tend to be thin in the lower Lockatong $(56 \mathrm{~m})$ and upper Passaic $(59 \mathrm{~m})$, thicker in the upper Lockatong (74 m), and thickest in the lower Passaic (84 m) (excluding the Jurassic part of the section). The compilation shows the relative constancy of the thickness of the members through the lacustrine strata (i.e., the McLaughlin modulating cycles), and the much greater thickness of the McLaughlin cycles of the Jurassic age strata $(\sim 100 \mathrm{~m})$ (c.f. Schlische and Olsen, 1990). Although the cyclical variations in sedimentary structures and color are the result of cyclical climate variations, the overall changes in sedimentation rate as seen in the thickness of the members of the Lockatong and Passaic formations are most likely due to tectonic changes (Olsen and Kent, 1995).

\section{AGE AND CORRELATION}

Cornet $(1977,1993)$ recognized four pollen and spore zones within the Newark basin section, and these provide the best presently available ties to the standard ages: the New Oxford-Lockatong palynofloral zone of late Carnian age, the Lower Passaic-Heidlersburg palynofloral zone of Norian age, the Balls Bluff-Upper Passaic palynofloral zone of "Rhaetian" age, and the Corollina mey- eriana zone of Early Jurassic (Hettangian?Sinemurian) age. The thickness of the Stockton Formation suggests that at least the lower half of that formation should be within Cornet's Chatham-Richmond-Taylorsville assemblage of ?early Carnian age.

The lowest assemblages belonging to the New Oxford-Lockatong palynofloral zone occur in the upper Stockton Formation in outcrop (Cornet and Olsen, 1985), and the uppermost assemblage of this zone occurs in member $\mathrm{C}$ of the Passaic Formation (called member B in Cornet, 1977). The lowest assemblage of the Lower Passaic-Heidlersburg palynofloral zone occurs in the Graters Member (Cornet, 1977), and the uppermost in member FF. The lowest assemblage of the Balls Bluff-Upper Passaic palynofloral zone occurs in the Cedar Grove Member of the Passaic Formation, and the uppermost in the middle Exeter Township Member of the Passaic Formation. The lowest assemblage of the Corollina meyeriana zone also occurs in the middle Exeter Township Member of the Passaic Formation and the uppermost one occurs just below the Boonton fish bed (Olsen, 1980a) of the Boonton Formation (Cornet, 1977). Strata overlying the latter unit have not been sampled for pollen and spores. 


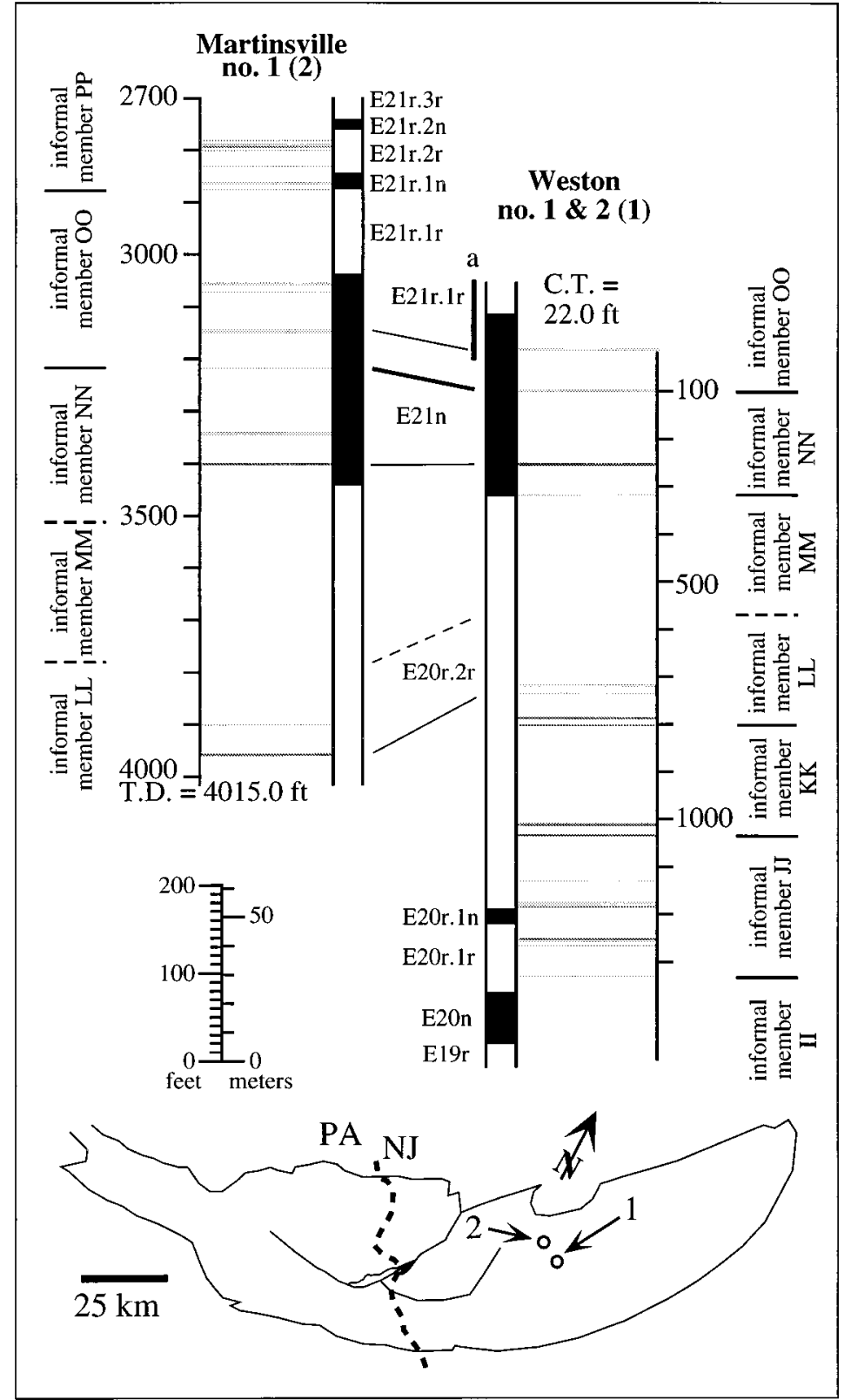

Figure 26. Overlap zone between Weston and Martinsville cores. Bar below letter a indicates portion of polarity stratigraphy based on surface chips using the method of Witte and Kent (1993) and outcrop.

The boundary between Carnian and Norian ages should thus fall between member $\mathrm{C}$ and the Graters Member, and the boundary between Norian and "Rhaetian" ages should be between member $\mathrm{FF}$ and the lower Cedar Hill Member. The "Rhaetian"Hettangian (Triassic-Jurassic) boundary evidently falls in a remarkably thin interval at least locally less than $1 \mathrm{~m}$ apart, within a single Van Houten cycle in the middle Ex- eter Township Member (Olsen et al., 1990; Fowell, 1993; Fowell and Olsen, 1993), just above polarity zone E23n.1r (Fig. 27).

Vertebrate assemblages from the Newark basin section support the palynological correlations (Olsen and Galton, 1977, 1984; Olsen and Sues, 1986; Cornet and Olsen, 1985). The presence of the phytosaur Rutiodon in the upper Stockton Formation and its probable presence in the Lockatong For- mation support a late Carnian age for those units (Lucas and Huber, 1993). Identification of the palynological placement of the Triassic-Jurassic boundary is supported by the absence of any evidence of uniquely Triassic vertebrates, especially ichnotaxa, within the abundantly footprint-rich strata of the Corollina meyeriana zone. Triassictype ichnotaxa occur $<5 \mathrm{~m}(<20000 \mathrm{yr})$ below the palynological Triassic-Jurassic boundary (Silvestri and Szajna, 1993; Szajna and Hartline, 1995), and bony remains are found as close to the boundary as the Pine Ridge Member (Olsen et al., 1987), within one McLaughlin cycle ( $400000 \mathrm{yr}$ ).

Reliable radiometric dates are available only from the Palisade sill within the Newark basin. This sill evidently fed the Preakness and possibly Orange Mountain basalts (Ratcliffe, 1986). The sill provides ${ }^{40} \mathrm{Ar} /{ }^{39} \mathrm{Ar}$ dates from biotites $(201 \pm 1 \mathrm{Ma}$, Sutter, 1988) and U-Pb dates from baddelyites (202 \pm 1 Ma, Dunning and Hodyich, 1990). This yields a combined date of 201-202 Ma for the palynological Triassic-Jurassic boundary that occurs just below the base of the Orange Mountain Basalt (Ratcliffe, 1986; Sutter, 1988; Dunning and Hodyich, 1990).

The cyclostratigraphy of the lacustrine part of the Newark basin section provides additional relative age calibration. Assuming that the McLaughlin cycles indeed represent the approximately $400000 \mathrm{yr}$ celestial mechanical cycle, the member divisions of the Passaic and Lockatong formations can provide additional, high-resolution chronological control (Olsen et al., 1994). Based on these assumptions the Lockatong Formation spans about 5.2 m.y., the Passaic Formation occupies about 16.7 m.y., and the Feltville about 0.3 m.y. The Stockton Formation is fluvial in origin and thus lacks lacustrine cycles. If its accumulation rate were similar to the overlying Lockatong, the Stockton Formation would represent about 6.8 m.y.

Paleomagnetic analysis of the NBCP cores has resulted in the development of a high-resolution, cyclostratigraphically calibrated geomagnetic polarity reference sequence for the Late Triassic (Kent et al., 1995). There is no comparable marine anomaly based time scale because there is no intact Triassic sea floor (Kent and Gradstein, 1986). However, recent developments in the polarity stratigraphy of marine sections in Europe and Turkey should help test the biostratigraphic correlations. 


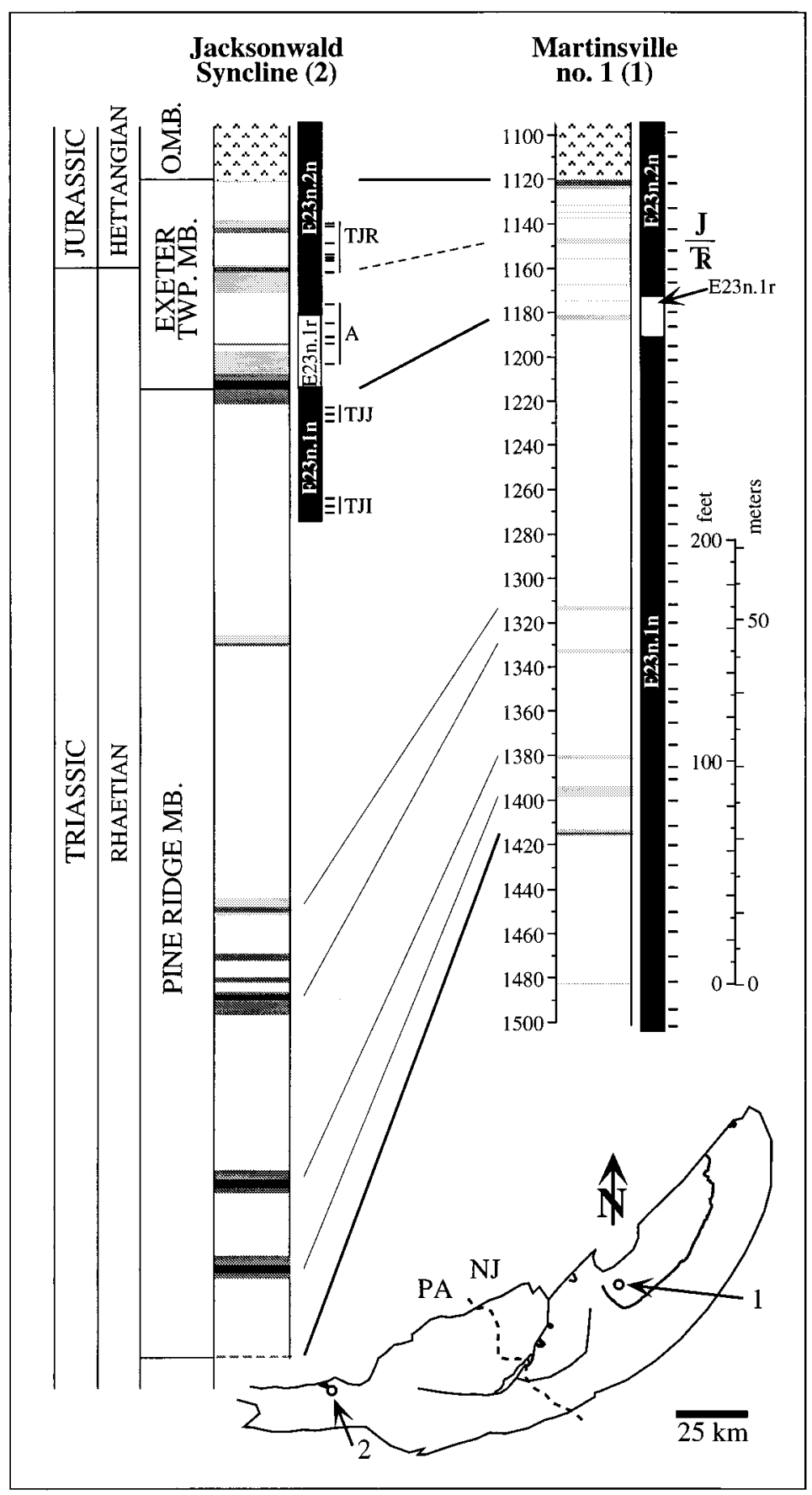

Figure 27. Correlation of the uppermost Passaic Formation in the Martinsville no. 1 core (1) with the type sections of the Pine Ridge and Exeter Township members and the palynologically identified Triassic-Jurassic boundary in the Jacksonwald syncline. Lithologic and paleomagnetic key as in Figure 13, and other abbreviations and symbols as follows: TJR, TJJ, TJI, symbols for sampling sites in Witte et al. (1991); A, samples processed for this work; horizontal ticks, sample sites. Upper part of section (to base of paleomagnetic samples) is based on exposures along Sycamore Drive, Exeter Township, Berks County, Pennsylvania, and the adjacent type section of the Exeter Township Member. Lower part of the section for Jacksonwald Syncline (below paleomagnetic samples) is based on temporary exposures along Constitution and Pennsylvania avenues, Exeter Township, Berks County, Pennsylvania, and type exposures of Pine Ridge Member along nearby creek. PA, Pennsylvania; NJ, New Jersey; O.M.B., Orange Mountain Basalt. 


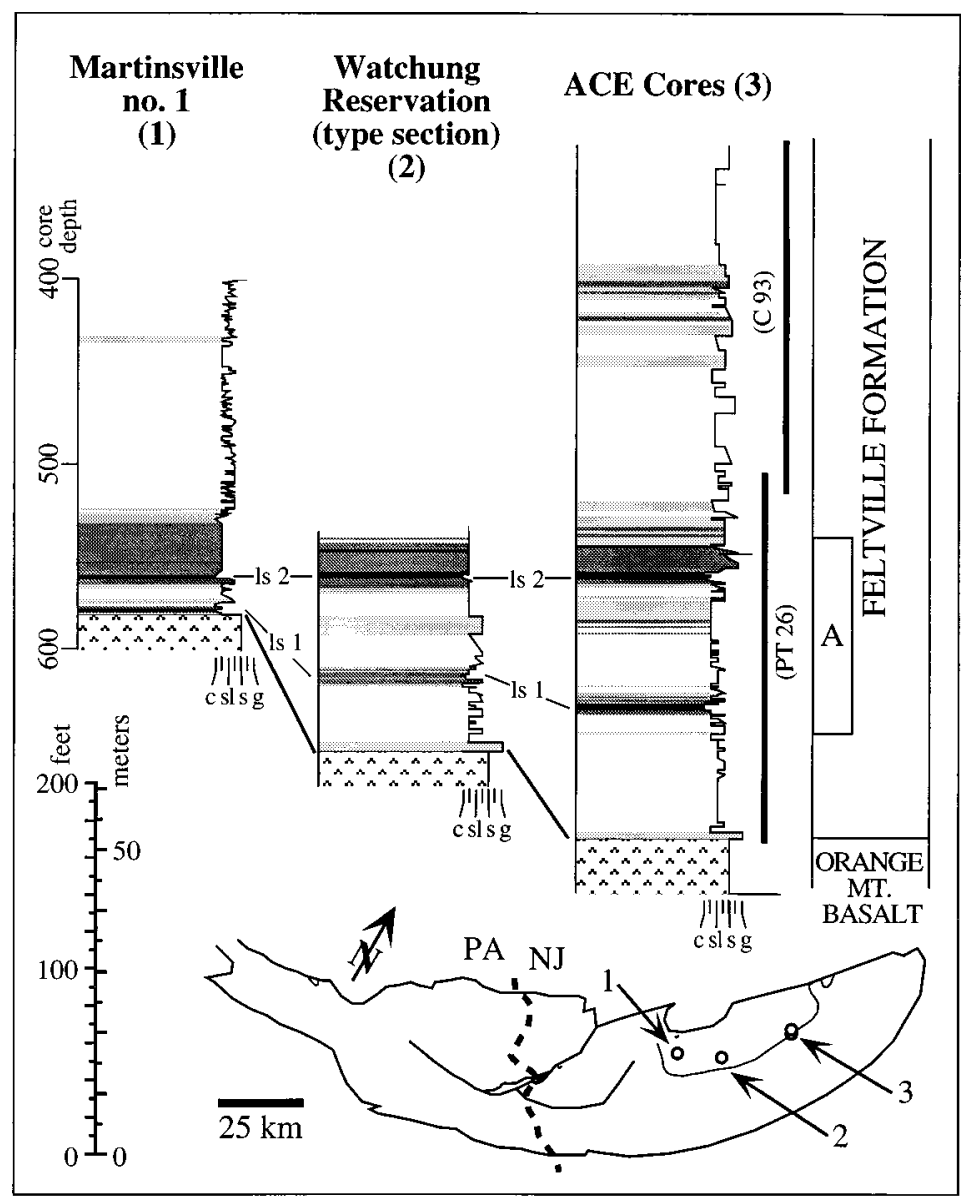

Figure 28. Comparison of the type section of Feltville Formation in Watchung Reservation (2), Martinsville no. 1 (1), and ACE cores (cores PT-26 and C-93) (3). A, interval designated the informal Washington Valley member. PA, Pennsylvania; NJ, New Jersey; c, claystone; sl, siltstone; s, sandstone; g, gravel; ls, limestone.

\section{DEPOSITIONAL ENVIRONMENTS AND CYCLICITY}

Depositional environments represented by the Newark basin section have been discussed by Arguden and Rudolfo (1986), Glaeser (1966), Olsen (1980c, 1984a, 1988b), Olsen et al. (1989), Smoot (1991), Smoot and Olsen $(1985,1988,1994)$, Turner-Peterson (1988), and Van Houten (1962, 1964, 1969, 1980). The Stockton Formation was deposited in a predominantly braided to meandering or anastomosing fluvial system grading into mixed fluvial-deltaic and shallow lake at the top (Smoot, 1991; Smoot and Olsen, 1994). The post-Stockton sedimentary formations were deposited primarily in very large, very flat playas. Periodically, perennial lakes were established, the depth of which varied cyclically. On average, deeper lakes were developed more frequently during the deposition of the Lockatong than the Passaic Formation, and the frequency of deep lakes decreased in a stepwise fashion through the Passaic. Alluvial fans and fluvial systems fed the lakes from the southeast hinge area during Lockatong time (Glaeser, 1966; Van Houten, 1969). During Passaic time, the water and sediment source for the lakes switched to an axial system from the narrow neck area (i.e., the Hammer Creek Formation) in the southwestern to western corner of the basin (Smoot, 1991). The NBCP cores show clearly that during deposition of all post-Stockton sedimentary formations, a remarkably consistent hierarchy of precipitation-evaporation-related lake level cycles resulted in the characteristic pattern of Van Houten cycles and the short, McLaughlin, and long modulating cycles.
Van Houten (1964, 1969), Olsen (1986), and Olsen et al. (1994) ascribed the Van Houten cycles to climatically driven lake-level fluctuations controlled by orbital variations, specifically the $\sim 20000 \mathrm{yr}$ climatic precession cycle. The short, McLaughlin, and long modulating cycles were caused by the effects of the planets on the figure of the Earth's orbit, producing fluctuations in the amplitude of the climatic precession cycle with periods approximating 109000,400000 , and $1900000 \mathrm{yr}$, respectively (Olsen, 1986; Olsen et al., 1994; see also Berger and Loutre, 1990; Laskar, 1990).

The Orange Mountain, Preakness, and Hook Mountain basalts were deposited as essentially lava lakes (Manspeizer, 1980), with individual ponded flows reaching a minimum area of several thousand square kilometers and a depth of over $130 \mathrm{~m}$ (Tollo and Gottfried, 1992; Puffer and Student, 1992). Although the basalt outpourings were large in magnitude, they evidently did not disrupt the sedimentation pattern to any great extent (Olsen et al., 1989). The cyclical pattern characteristic of the Lockatong and Passaic formations continued unabated into the sedimentary formations interstratified with and overlying the lava flow formations (Feltville, Towaco, and Boonton), albeit with a much higher sedimentation rate (Olsen et al., 1989).

\section{CONCLUSIONS}

The over $6770 \mathrm{~m}$ of continuous core from the Newark rift basin shows that the formations of the Newark basin largely retain their outcrop character at depth and throughout most of the basin. The cores show unambiguously that the hierarchical pattern of cycles originally described from outcrop is characteristic of the entire post-Stockton sedimentary sequence. Lacustrine conditions persisted uninterrupted in the Newark basin for the 24 m.y. duration of this interval, and the McLaughlin cycles, thought to be the result of the 413 k.y. eccentricity cycle, allow the sequence to be subdivided into 53 consistently defined members. The magnetostratigraphy and cyclostratigraphy of the core and between the core and outcrops show that the full hierarchy of lacustrine cycles can be traced over more than $100 \mathrm{~km}$ - essentially basinwide. The remarkably consistent agreement of the magnetostratigraphy and the cyclostratigraphy between overlap intervals of the core and between the core and outcrops shows that, within the limits of our sampling resolution, both the highstand portions of 

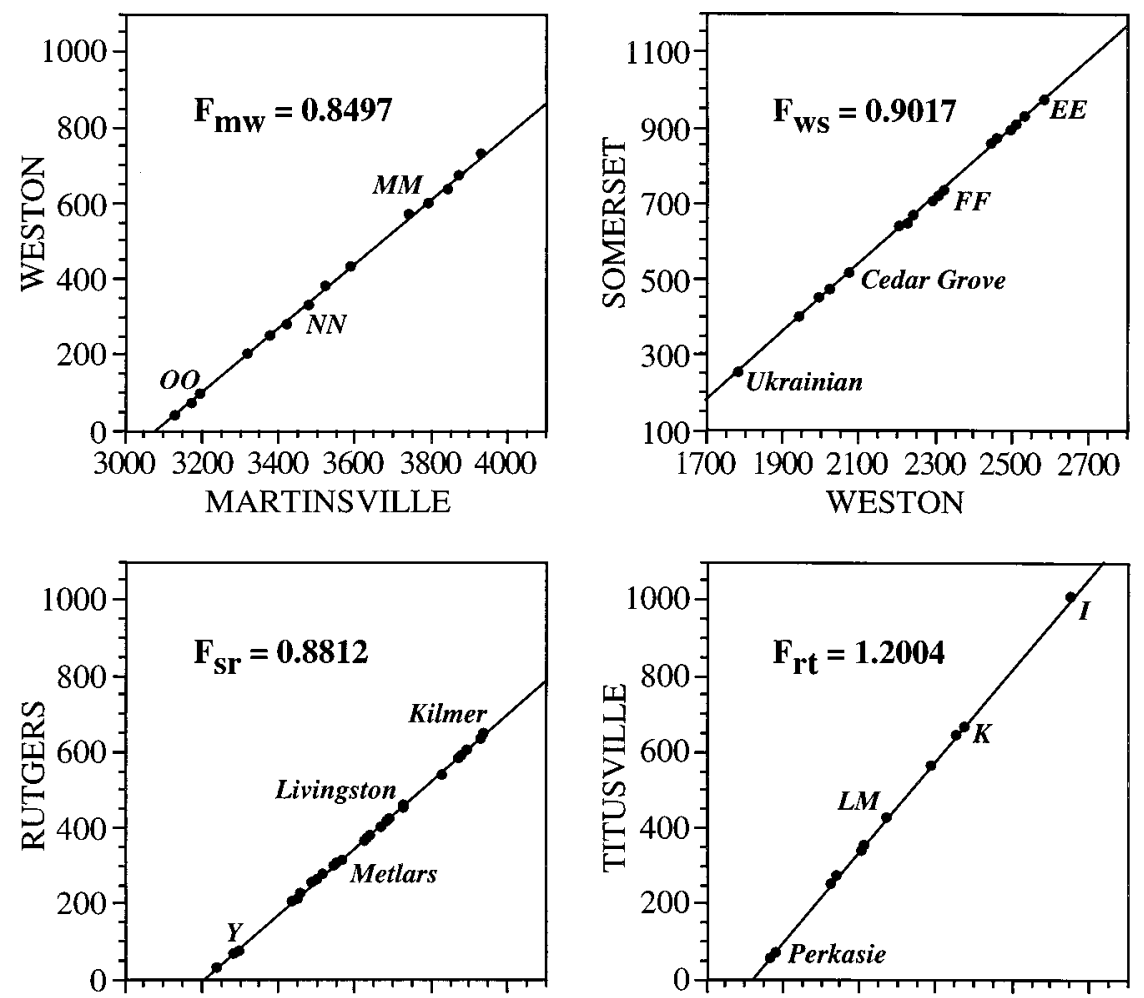

190021002300250027002900

SOMERSET

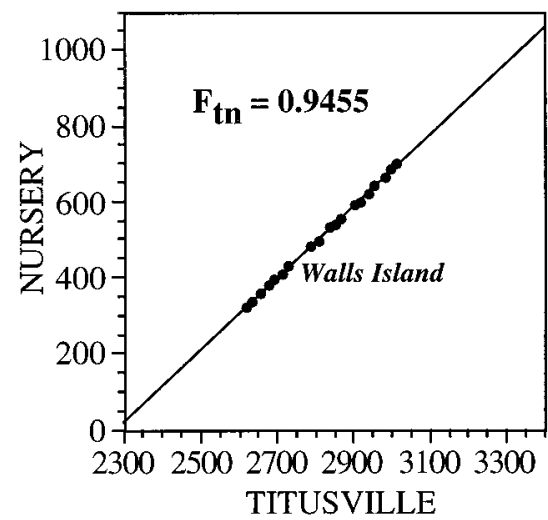

scale laterally recognizable stratigraphic units that have time significance. Both the lateral continuity and isochroneity of the units has been repeatedly and consistently tested and corroborated. The stratigraphy of the Newark basin provides a template for a Late Triassic astronomically calibrated time scale for cyclostratigraphy, and magnetostratigraphy, which will ultimately allow global correlations at the same level of resolution as in the Neogene (Olsen and Kent, 1995; Kent et al., 1995). It provides a basis for understanding tropical climate over an unprecedented duration of time and will provide the basis for deciphering the interplay of climate and tectonic processes in a continental rift.

\section{ACKNOWLEDGMENTS}

We are especially grateful to the owners and managers of the land upon which we drilled, particularly David H. Knights of the Princeton Forrestal Center of Princeton University and Alan Jones of Princeton Nurseries, David Stern of the Mercer Co. Department of Public Works, Frances Birdsall Zelinski and James Birdsall of Fieldview Farms, Elmer Smith of Bear Tavern Farm, Vernie R. Costan and William S. Richardson of Rutgers University, and Bruce Keeler and Robert Shay of the Somerset County Park Commission. Amoco Production Company is thanked for their enthusiastic and skillful drilling and core processing of the first six core hole sites using their SHADS (Scientific High-Speed Advanced Drilling System); specifically, we thank Kenneth Ciriacks, Donald Boyne, Lynne Feldkamp, Keith Milheim, David Bode, David Skidmore, Scott Randolf, Scott Gavin, Eric Cunningham, and Randy Sprague. DOSECC (Deep Observation and Sampling of the Earth's Continental Crust) management personnel, Longyear Drilling Company, and Exlog, Inc., are thanked for their able coring and processing of the last site-particularly, Earl Hoskins and Roland Lawrence of DOSECC, William Dycus and DuWayne Stoots of Longyear, and Thomas Paulson and Warren Wilkes of Exlog. William Stothoff and Co. are thanked for their capable drilling of the water wells and cased holes. David Goldberg of Lamont and BPB Inc. are thanked for their skill in logging the holes. Michael J. Miller, Robert Mancini, and Richard Dalton of the New Jersey Department of Environmental Protection were extraordinarily helpful in guiding the permitting stage of the project, and Columbia 


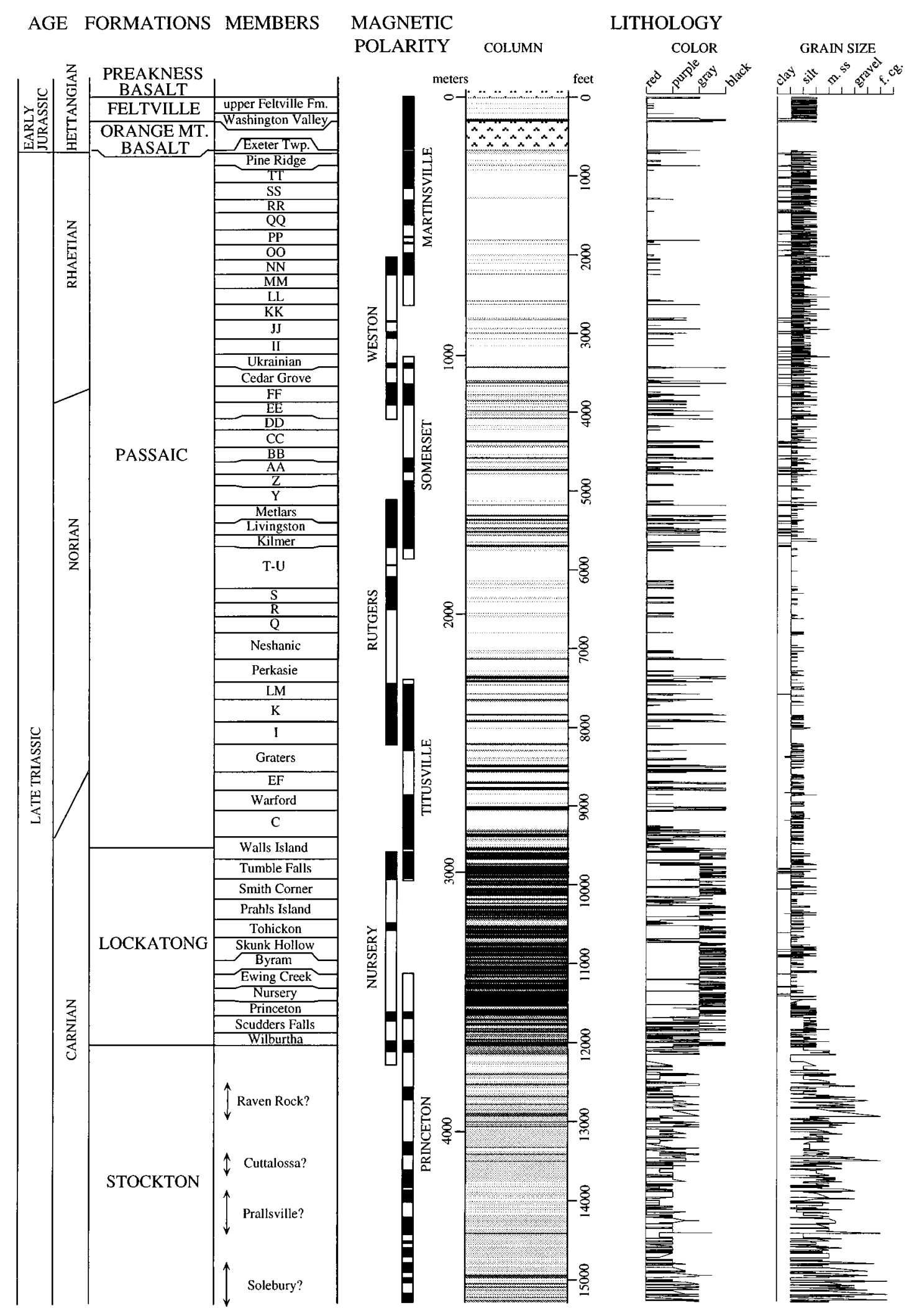

Figure 30. Composite section of Newark Basin Coring Project Cores. All cores have been scaled to the Rutgers no. 1 and 2 cores. 
University's Office of the General Counsel, particularly Susan Sgarlat, were a constant, valuable asset throughout. Barry Raleigh (now at University of Hawaii) is thanked for encouraging us to propose the NBCP, as is Loren Cox of Lamont-Doherty Earth Observatory for initiating our involvement with Amoco and for helpful guidance during many stages of the project.

We also thank Marjorie Levy for assistance in mapping the Pennington and Princeton quadrangles and Hugh Houghton and Dick Dalton of the New Jersey Department of Environmental Protection and ShayMaria Silvestri and Brian Jones of Rutgers University for their unpublished map data. Joseph Smoot and Bruce Simonson are acknowledged for unpublished measured sections that formed the basis of Figure 14 and for many fruitful discussions. Sarah Fowell is thanked for her data on the TriassicJurassic boundary and for processing and examination of many samples for palynology. David Reynolds is warmly acknowledged for his analysis of the logs from the core holes and editing of the manuscript prior to submission and, along with Sarah Fowell, is thanked for many fruitful hours of discussion on the project. We also thank Annika K. Johansson, Martin H. Link, William Last, Spencer G. Lucas, Martha O. Withjack, and an anonymous reviewer for many suggestions that substantially improved the manuscript.

We gratefully acknowledge the support of this project by the Continental Dynamics Program (Dr. Leonard Johnson, Program Manager) of the National Science Foundation (grant no. EAR 89-16726 to Olsen and Kent). Additional funds were provided by the National Science Foundation (EAR 9017785) and a grant from the Rutgers University Research Council to Schlische.

\section{REFERENCES CITED}

Arguden, A. T., and Rudolfo, K. S., 1986, Sedimentary facies and tectonic implications of lower Mesozoic alluvial-fan conglomerates of the Newark basin, northeastern United States: Sedimentary Geology, v. 51, p. 97-118.

Baird, D., 1957, Triassic reptile footprint faunules from Milford, New Jersey: Museum of Comparative Zoology (Harvard University) Bulletin, v. 117, p. 449-520.

Bascom, F., Clark, W. B., Darton, N. H., Kümmel, H. B., Salisbury, R. D., Miller, B. L., and Knapp, G. N., 1909a, Philadelphia folio: U.S. Geological Survey Folio 162, scale 1:62 500.

Bascom, F. Darton, N. H., Kümmel, H. B., Clark, W. B., Miller, B. L., and Salisbury, R. D., 1909b, Trenton folio, New Jersey: U.S. Geological Survey Atlas of the United States, no. 167,5 maps, 25 p.

Bayley, W. S., Salisbury, R. D., and Kümmel, H. B., 1914, Raritan folio, New Jersey: U.S. Geological Survey Atlas of the United States, no. 191, 5 maps, $32 \mathrm{p}$

Berger, A., and Loutre, M.-F., 1990, Origine des fréqences des élements astronomiques intervenant dans le calcul de l'insolation: Bulletin de la Classe des Science (Académie Royale de Belgique), 6th ser., v. 1, p. 45-106.

Cornet, B., 1977, The palynostratigraphy and age of the Newark Supergroup [Ph.D. thesis]: University Park, Pennsylvania, Pennsylvania State University, 504 p.
Cornet, B., 1993, Applications and limitations of palynology in age, climatic, and paleoenvironmental analyses of Triassic sequences in North America, in Lucas, S. G., and Morales, M., eds., The nonmarine Triassic: New Mexico Museum of ural History and Science Bulletin No. 3, p. 75-93.

Cornet, B., and Olsen, P. E., 1985, A summary of the biostratigraphy of the Newark Supergroup of eastern North America with comments on early Mesozoic provinciality: III Congresso Latinoamericano de Paleontologia, Mexico, 1985, gresso Latinoamericano de Paleontologia, Mexico, 1985,
Simposia Sobre Floras del Triasico Tardio, su FitoSimposia Sobre Floras del Triasico Tardio,
geographia y Paleoecologia, Memoria, p. 67-81.

Cornet, B., and Traverse, A., 1975, Palynological contribution to the chronology and stratigraphy of the Hartford basin in the chronology and stratigraphy of the Hartford basin in
Connecticut and Massachusetts: Geoscience and Man, v. 11, p. 1-33.

Cornet, B., Traverse, A., and McDonald, N. G., 1973, Fossil spores, pollen, and fishes from Connecticut indicate Early Jurassic age for part of the Newark Group: Science, v. 182, no. 4118 , p. $1243-1246$

Darton, N. H., 1889, On the great lava flows and intrusive trap sheets of the Newark System of New Jersey: American Journal of Science, v. 38 , no. 224, p. 134-139.

Darton, N. H., 1890, The relations of the traps of the Newark system in the New Jersey region: U.S. Geological Survey Bulletin 67, $82 \mathrm{p}$

Drake, A. A., McLaughlin, D. B., and Davis, R. A., 1961, Geology of the Frenchtown quadrangle, New Jersey-Pennsylvania: U.S. Geological Survey Quadrangle Map GO 133, scale 1:24 000

Dunning, G. R., and Hodych, J. P., 1990, U/Pb zircon and baddeleyite ages for the Palisades and Gettysburg sills of the northeastern United States: Implications for the age of the Triassic-Jurassic boundary: Geology, v. 18, p. 795-798.

El Tabakh, M., and Schreiber, C., 1994, Lithologies and diagenesis of the lacustrine sediments of the Lockatong Formation (Upper Triassic) in the Newark rift basin, in Lomando, T., (Upper Triassic) in the Newark rift basin, in Lomando, T., and Harris, M., eds., Lacustrine depositional

Faust, G. T., 1978, Joint systems in the Watchung basalt flows, New Jersey: U.S. Geological Survey Professional Paper 864B, p. B1-B42.

Fedosh, M. S., and Smoot, J. P., 1988, A cored stratigraphic section through the northern Newark basin, New Jersey, in Robinson, G. R., and Froelich, A. J., eds., Proceedings of the second U.S. Geological Survey workshop on the Early Mesozoic basins of the eastern United States: U.S. Geological Survey Circular 946, p. 19-24.

Fowell, S. J., 1993, Palynology of Triassic/Jurassic boundary sections from the Newark Supergroup of eastern North Amerthesis]: New York, Columbia University, 133 p.

Fowell, S. J., and Olsen, P. E., 1993, Time-calibration of Triassic/ Jurassic microfloral turnover, eastern North America: Tectonophysics, v. 222 , p. 361-369.

Fowell, S. J., Cornet, B., and Olsen, P. E., 1994, Geologically rapid Late Triassic extinctions: Palynological evidence from the Newark Supergroup, in Klein, G. D., ed., Pangea: Paleoclimate, tectonics and sedimentation during accretion, zenith and break-up of a supercontinent: Geological Society of America Special Paper 288, p. 197-206.

Froelich, A. J., and Olsen, P. E., 1984, Newark Supergroup, a revision of the Newark Group in eastern North America: revision of the Newark Group in eastern North Ame

Glaeser, J. D., 1963, Lithostratigraphic nomenclature of the Triassic Newark-Gettysburg basin: Pennsylvania Academy of Science Proceedings, v. 37, p. $179-188$

Glaeser, J. D., 1966, Provenance, dispersal, and depositional environments of Triassic sediments in the Newark-Gettysburg basin: Pennsylvania Geological Survey Bulletin G-43, 168 p.

Goldberg, D., Reynolds, D., Williams, C., Witte, W. K., Olsen, P. E., and Kent, D. V., 1994, Well logging results from the Newark Rift Basin Coring Project: Scientific Drilling, v. 4, no. 4-6, p. 267-279.

Hilgen, F. J., 1991, Extension of the astronomically calibrated (poarity) time scale to the Miocene/Pliocene boundary: Earth and Planetary Science Letters, v. 107, p. 349-368.

Houghton, H. F., Herman, G. C., and Volkert, R. A., 1992, Igneous rocks of the Flemington fault zone, central Newark basin, in Puffer, J. H., and Ragland, P. C., eds., Eastern North American Mesozoic magmatism: Geochemistry, structure, and stratigraphy: Geological Society of America Special Paper 268, p. 219-232.

Johnson, M. E., and McLaughlin, D. B., 1957, Triassic formations in the Delaware Valley, in Dorf, E., ed., Guidebook for field trips: Geological Society of America, Annual Meeting, Attrips: Geological Society of America, Ann

lantic City, New Jersey, Field Trip 2, 38 p.
Jones, B. B., 1994, The structure and stratigraphy of the Hopewell fault block, Newark basin, New Jersey and Pennsylvania [Master's thesis]: New Brunswick, New Jersey, Rutgers University, $101 \mathrm{p}$.

Kent, D. V., Olsen, P. E., and Witte, W. K., 1995, Late TriassicEarly Jurassic geomagnetic polarity sequence and paleolatitudes from drill cores in the Newark rift basin (eastern North America): Journal of Geophysical Research, v. 100, no. B8, p. $14965-14998$.

Kümmel, H. B., 1898, The Newark System or red sandstone belt: New Jersey Geological Survey Annual Report of the State Geologist for the Year of 1897, p. 23-159.

Laskar, J., 1990, The chaotic motion o merical estimate of the size of the Chaotic Zones: Icarus, v. 88 , p. $266-291$
Lehmann, E. P., 1949, The bedrock geology of the Middletown quadrangle: Connecticut Geological and Natural History Survey Quadrangle Report 8, $40 \mathrm{p}$.

Lewis, J. V., 1907, The Newark (Triassic) copper ores of New Jersey: New Jersey Geological Survey, Annual Report of the State Geologist, 1906, p. 131-164.

Lucas, S. G., and Huber, P., 1993, Revised internal correlation of the Newark Supergroup Triassic, eastern United States and Canada, in Lucas, S. G., and Morales, M., eds., The nonmarine Triassic: New Mexico Museum of Natural History and Science Bulletin No. 3, p. 311-319.

Luttrell, G. W., 1989, Stratigraphic nomenclature of the Newark Supergroup of eastern North America: U.S. Geological Survey Bulletin $1572,136 \mathrm{p}$

Lyman, B. S., 1895, Report on the New Red of Bucks and Montgomery Counties, Pennsylvania: Pennsylvania Geolog ical Survey, 2nd Summary Final Report, no. 3, pt. 2, p. 2589-2638.

Lyttle, P. T., and Epstein, J. B., 1987, Geologic map of the Newark $1^{\circ}$ by $2^{\circ}$ quadrangle, New Jersey, Pennsylvania, and New
York: U.S. Geological Survey Miscellaneous Investigations Map I-1715, scale 1:250 000.

Manspeizer, W., 1980, Rift tectonics inferred from volcanic and clastic structures, in Manspeizer, W., ed., Field studies of New Jersey geology and guide to field trips: New York State Geological Association, 52nd Annual Meeting, Rutgers University, Newark, New Jersey, p. 314-350.

Manspeizer, W., 1988, Triassic-Jurassic rifting and opening of the Atlantic: An overview, in Manspeizer, W., ed., Triassic-
Jurassic rifting, continental breakup, and the formation of the Atlantic Ocean and passive margins, Part A: Amsterdam, Netherlands, Elsevier, p. 41-79.

McIntosh, W.C., Hargraves, R. B., and West, C. L., 1985, Paleomagnetism and oxide mineralogy of Upper Triassic to Lowe Jurassic red beds and basalts in the Newark basin: Geological Society of America Bulletin, v. 96, p. 463-480.

McLaughlin, D. B., 1933, A note on the stratigraphy of the Brunswick Formation (Newark) in Pennsylvania: Michigan Academy of Science, Arts, and Letters, v. 18, p. 59-74.

McLaughlin, D. B., 1943, The Revere Well and Triassic stratigraphy: Pennsylvania Academy of Science Proceedings, v. 17, p. $104-110$.

McLaughlin, D. B., 1944, Triassic stratigraphy in the Point Pleasant district, Pennsylvania: Pen

McLaughlin, D. B., 1945, Type sections of the Stockton and Lockatong Formations: Proceedings of the Pennsylvania Academy of Science, v. 19, p. 102-103.

McLaughlin, D. B., 1946a, The Triassic rocks of the Hunterdon Plateau, New Jersey: Proceedings of the Pennsylvania Academy of Science, v. 20, p. 89-98.

McLaughlin, D. B., 1946b, Continuity of strata in the Newark Series: Michigan Academy of Science, Arts, and Letters v. 32 , p. $295-303$

McLaughlin, D. B., 1959, Mesozoic rocks, in Willard, B., et al, Geology and mineral resources of Bucks County, Pennsylvania: Pennsylvania Geological Survey Bulletin C-9, p. $55-114$

Olsen, P. E., 1978, On the use of the term Newark for Triassic and Early Jurassic rocks in eastern North America: Newsletter on Stratigraphy, v. 7, no. 2, p. 90-95.

Olsen, P. E., 1980a, The latest Triassic and Early Jurassic formations of the Newark basin (eastern North America, Newark Supergroup): Stratigraphy, structure, and correlation: New Jersey Academy of Science Bulletin, v. 25, p. 25-51.

Olsen, P. E., 1980b, Triassic and Jurassic formations of the Newark basin, in Manspeizer, W., ed., Field studies of New Jersey geology and guide to field trips: New York State Geological Association, 52nd Annual Meeting, Newark, New Jersey, Rutgers University, p. 2-39.

Olsen, P. E., 1980c, Fossil great lakes of the Newark Supergroup in New Jersey, in Manspeizer, W., ed., Field studies of New Jersey geology and guide to field trips: New York State Geological Association, 52nd Annual Meeting, Newark, New Jersey, Rutgers University, p. 352-398.

Olsen, P. E., 1984a, Comparative paleolimnology of the Newark Supergroup-A study in ecosystem evolution [Ph.D. thesis] New Haven, Connecticut, Yale University, 726 p.

Olsen, P. E., 1984b, Periodicity of lake-level cycles in the Late Triassic Lockatong Formation of the Newark basin, in Berger, A., et al., eds., Milankovitch and climate, Part 1: Boston, Massachusetts, D. Reidel Publishing Company, p. $129-146$.

Olsen, P. E., 1986, A 40-million year lake record of early Mesozoic orbital climatic forcing: Science, v. 234, no. 4778 p. $842-848$.

Olsen, P. E., 1988a, Continuity of strata in the Newark and Hartford basins of the Newark Supergroup: U.S. Geological Survey Bulletin 1776, p. 6-18.

Olsen, P. E., 1988b, Paleoecology and paleoenvironments of the continental early Mesozoic Newark Supergroup of eastern North America, in Manspeizer, W., ed., Triassic-Jurassic rifting, continental breakup, and the formation of the At lantic Ocean and passive margins, Part A: Amsterdam Netherlands, Elsevier, p. 185-230.

Olsen, P. E., and Baird, D., 1986, The ichnogenus Atreipus and it significance for Triassic biostratigraphy, in Padian, K., ed., The beginning of the age of dinosaurs, faunal change across the Triassic-Jurassic boundary: New York, Cambridge University Press, p. 61-87. 
Olsen, P. E., and Galton, P. M., 1977, Triassic-Jurassic extinctions: Are they real?: Science, v. 197, p. 983-986.

Olsen, P. E., and Galton, P. M., 1984, A review of the reptile and amphibian assemblages from the Stormberg of southern Africa, with special emphasis on the footprints and the age of the Stormberg: Palaeontologia Africana, Haughton Memorial Volume, v. 25, p. 92-116.

Olsen, P. E., and Kent, D. V., 1995, Milankovitch climate forcing in the tropics of Pangea during the Late Triassic: Palaeogeography, Palaeoclimatology, and Palaeoecology (in press).

Olsen, P. E., Fowell, S. J., and Cornet, B., 1990, The Triassic/ Jurassic boundary in continental rocks of eastern North America; A progress report, in Sharpton, V. L., and Ward, America; A progress report, in Sharpton, V. L., and Ward,
P. D., eds., Global catastrophes in earth history: Geological Society of America Special Paper 247, p. 585-593.

Olsen, P. E., and Sues, H.-D., 1986, Correlation of the continental Late Triassic and Early Jurassic sediments, and patterns of the Triassic-Jurassic tetrapod transition, in Padian, K., ed., The beginning of the age of dinosaurs, faunal change across The beginning of the age of dinosaurs, faunal change across
the Triassic-Jurassic boundary: New York, Cambridge Unithe Triassic-Jurassic boun

Olsen, P. E., Shubin, N. H., and Anders, M. H., 1987, New Early Jurassic tetrapod assemblages constrain Triassic-Jurassic tetrapod extinction event: Science, v. 237, p. 1025-1029.

Olsen, P. E., Schlische, R. W., and Gore, P. J. W., eds., 1989, Tectonic, depositional, and paleoecological history of the Newark Supergroup, eastern North America (International Geological Congress, Field Trip T351): Washington, D.C., American Geophysical Union, $174 \mathrm{p}$

Oriel, S. S., ed., 1983, North American stratigraphic code (North American Commission on Stratigraphic Nomenclature): American Association of Petroleum Geologists Bulletin, v. 67 , no. 5 , p. $841-875$.

Parker, R. A., and Houghton, H. F., compilers, 1990, Bedrock geology map of the Monmouth Junction quadrangle, New Jersey: U.S. Geological Survey Open-File Report 90-219, scale 1:24000.

Puffer, J. H., 1984, Volcanic rocks of the Newark basin, in Puffer, J. H., ed., Igneous rocks of the Newark basin: Petrology, J. H., ed., Igneous rocks of the Newark basin: Petrology,
mineralogy, ore deposits and guide to field trip: Geological mineralogy, ore deposits and guide to field trip: Geological Kean College, Union, New Jersey, p. 45-60.

Kean College, Union, New Jersey, p. 45-60.
Puffer, J. H., and Student, J. J., 1992, Volcanic structures, eruptive styles, and post eruptive deformation and chemical alteration of the Watchung flood basalts, New Jersey, in Puffer, J. H., and Ragland, P. C., eds., Eastern North American Mesozoic magmatism: Geochemistry, structure, and stratig-
raphy: Geological Society of America Special Paper 268, raphy: Geolog
p. $261-277$.

Puffer, J. H., Hurtubise, D. O., Geiger, F. J., and Lechler, P., 1981, Chemical composition and stratigraphic correlation of Mesozoic basalt units of the Newark basin, New Jersey, and the Hartford basin, Connecticut: Geological Society of America Bulletin, v. 92, part 1, p. 155-159, part 2, p. 515-553.

Ratcliffe, N. M., 1988, Reinterpretation of the relationships of the western extension of the Palisades sill to the lava flows at Ladentown, New York, based on new core data, in Froelich, A. J., and Robinson, G. R., eds., Studies of the early Mesozoic basins of the eastern United States: U.S. Geological Survey Bulletin 1776, p. 113-135.

Ratcliffe, N. M., and Burton, W. C., 1984, Fault reactivation models for origin of the Newark basin and studies related to eastern United States seismicity, in Robinson, G. R., and Froelich, A. J., eds., Proceedings of the Second U.S. GeoFroelich, A. J., eds., Proceedings of the Second U.S. Geo-
logical Survey Workshop on the Early Mesozoic Basins of logical Survey Workshop on the Early Mesozoic Basins of 946, p. 36-45.

Ratcliffe, N. M., and Burton, W. C., 1988, Structural analysis of the Furlong fault and the relation of mineralization to faulting and diabase intrusion, Newark basin, Pennsylvania, in Froe- lich, A. J., and Robinson, G. R., eds., Studies of the early Mesozoic basins of the eastern United States: U.S. Geological Survey Bulletin 1776, p. 176-193.

Redfield, W. C., 1856, On the relations of the fossil fishes of the sandstone of Connecticut and the Atlantic states to the ds: American Journal of Science, ser. 2, v. 22, p. 357-363.

Reynolds, D. J., 1994, Sedimentary basin evolution: Tectonic and climatic interaction [Ph.D. thesis]: New York, Columbia University, 331 p.

Rima, D. M., Meisler, H., and Longwill, S. M., 1962, Geology and hydrology of the Stockton Formation in southeastern Pennsylvania: Pennsylvania Geological Survey Bulletin W14, 4th ser., $111 \mathrm{p}$.

4th ser., 111 p.
Roden, M. K., and Miller, D. S., 1991, Tectonothermal history of Hartford, Deerfield, Newark, and Taylorsville basins, eastHartford, Deerfield, Newark, and Taylorsville basins, east-
ern United States, using fission-track-analysis: Schweizern United States, using fission-track-analysis: Schweiz-
erische Mineralogische und Petrographische Mitteilungen, erische Mineralogise
v. 71, p. $187-203$.

Schlische, R. W., 1992, Structural and stratigraphic development of the Newark extensional basin: Evidence for the growth of the basin and its bounding structures: Geological Society of America Bulletin, v. 104, p. 1246-1263.

Schlische, R. W., 1994, Tectonostratigraphic significance of Newark basin core and outcrop data: Geological Society of America Abstracts with Programs, v. 26, no. 7, p. A336.

Schlische, R. W., and Olsen, P. E., 1990, Quantitative filling models for continental extensional basins with applications to the early Mesozoic rifts of eastern North America: Journal of Geology, v. 98 , p. $135-155$.

Scotese, C. R., 1986, Phanerozoic reconstructions: A new look at the assembly of Asia: University of Texas Institute for Geophysics Technical Report, v 66, $54 \mathrm{p}$.

Silvestri, S. M., 1994, Facies analysis of lake cycle in Newark basin cores and outcrops: Geological Society of America $\mathrm{Ab}-$ stracts with Programs, v. 26, no. 7, p. A402.

Silvestri, S. M., and Schlische, R. W., 1992, Analysis of Newark basin drill cores and outcrop sections: Tectonic and climatic controls on lacustrine facies architecture: Geological Society of America Abstracts with Programs, v. 24, no. 3, p. 76.

Silvestri, S. M., and Szaina, M. J., 1993, Biostratigraphy of vertebrate footprints in the Late Triassic section of the Newark basin, Pennsylvania: Reassessment of stratigraphic ranges, in Lucas, S. G., and Morales, M., eds., The nommarine Triassic: New Mexico Museum of Natural History and Science Bulletin No. 3, p. 439-445.

Smith, R. C., 1973, Geochemistry of Triassic of southeastern Pennsylvania [Ph.D. thesis]: University Park, Pennsylvania State University, $262 \mathrm{p}$

Smith, R. C., Berkheiser, S. W., Jr., and Barnes, J. H., 1989, Strange clay baffles geologists: Pennsylvania Geology, v. 19, no. 6 , p. $8-13$.

Smoot, J. P., 1991, Sedimentary facies and depositional environments of early Mesozoic Newark Supergroup basins, eastern North America: Palaeogeography, Palaeoclimatology, Palaeoecology, v. 84 , p. $369-423$.

Smoot, J. P., and Olsen, P. E., 1985, Massive mudstones in basin analysis and paleoclimatic interpretation of the Newark Supergroup, in Robinson, G. R., and Froelich, A. J., eds., Proceedings of the Second U.S. Geological Survey Workshop on the Early Mesozoic Basins of the Eastern United States: U.S. Geological Survey Circular 946, p. 29-33.

Smoot, J. P., and Olsen, P. E., 1988, Massive mudstones in basin analysis and paleoclimatic interpretations, in Manspeizer, the origin of the Atlantic Ocen assive margins, Part A: Amsterdam, Nether

Smoot, J. P., and Olsen, P. E., 1994, Climatic cycles as sedimentary controls of rift basin lacustrine deposits in the early Mesozoic Newark basin based on continuous core, in Lomando,
T., and Harris, M., eds., Lacustrine depositional systems: Society of Sedimentary Geology (SEPM) Core Workshop Notes, v. 19, p. 201-237.

Steckler, M. S., Omar, G. I., Karner, G. D., and Kohn, B. P., 1993 Pattern of hydrothermal circulation within the Newark basin from fission-track analysis: Geology, v. 21, p. 735-738.

Sutter, J. F., 1988, Innovative approaches to dating igneous events in the early Mesozoic basins, eastern North America, in Froelich, A. J., and Robinson, G. R., eds., Studies of the early Mesozoic basins of the eastern United

Geological Survey Bulletin 1776, p. 194-200.
Szajna, M. J., and Hartline, B., 1995, New vertebrate footprint assemblages from the Rhaetian interval of the Passaic Formation in Berks County, Pennsylvania: Geological Society mation in Berks County, Pennsylvania: Geological Society
of America Abstracts with Programs, v. 27, no. 1, p. 86.

Tollo, R. P., and Gottfried, D., 1992, Petrochemistry of Jurassic basalt from eight drill cores, Newark basin, New Jersey: Implications for the volcanic petrogenesis of the Newark Suplications for the volcanic petrogenesis of the Newark Supergroup, in Puffer, J. H., and Ragland, P. C., eds., Eastern North American Mesozoic magmatism: Ge
of America Special Paper 268, p. 233-259.

Turner-Peterson, C., 1988, A comparison of uranium-bearing sequences in the Newark basin, Pennsylvania and New Jersey, and the San Juan basin, New Mexico, in Froelich, A. J., and Robinson, G. R., eds., Studies of the early Mesozoic basins of the eastern United States: U.S. Geological Survey Bulletin 1776 , p. $350-356$

Van Houten, F. B., 1962, Cyclic sedimentation and the origin of analcime-rich upper Triassic Lockatong Formation, westcentral New Jersey and adjacent Pennsylvania: American Journal of Science, v. 260, p. 561-576.

Van Houten, F. B., 1964, Cyclic lacustrine sedimentation, Upper Triassic Lockatong Formation, central New Jersey and adjacent Pennsylvania, in Mermaid, O. F., ed., Symposium on 169 , p. $497-531$.

Van Houten, F. B., 1969, Late Triassic Newark Group, northcentral New Jersey and adjacent Pennsylvania and New York, in Subitzki, S., ed., Geology of selected areas in New Jersey and eastern Pennsylvania and guidebook of excurJersey and eastern Pennsylvania and guidebook of excurAmerica, Field Trip 4): Atlantic City, New Jersey, Rutgers America, Field Trip 4): Atla

Van Houten, F. B., 1980, Late Triassic part of Newark Supergroup, Delaware River section, west central New Jersey, in Manspeizer, W., ed., Field studies of New Jersey geology and guide to field trips. New York State Geological Association, 52nd Annual Meeting, Newark, New Jersey, Rutgers University, p. 264-269.

Wheeler, G., 1939, Triassic fault-line deflections and associated warping: Journal of Geology, v. 47, p. 337-370.

Witte, W. K., and Kent, D. V., 1990, The paleomagnetism of redbeds and basalts of the Hettangian extrusive zone, Newark basin: Journal of Geophysical Research, v. 95, p. $17533-17546$

Witte, W. K., and Kent, D. V., 1993, Magnetostratigraphy from unoriented bedrock regolith and unoriented well cuttings: Eos (Transactions, A

Witte, W. K., Kent, D. V., and Olsen, P. E., 1991, Magnetostratigraphy and paleomagnetic poles from Late Triassic-earliest Jurassic strata of the Newark basin: Geological Society of America Bulletin, v. 103, p. 1648-1662.

MANuscript Received by the SOCIETy November 22, 1994 REVISED MANUSCRIPT RECEIVED MAY 25, 1995

LAMONT-DOHERTY EARTH OBSERVATORY CONTRIBUTION No. 5416 